\title{
History and Nostalgia in Downtown Baltimore: \\ The Camden Warehouse and the Pratt Street Power Plant from Original \\ Construction to Adaptive Reuse
}

\author{
Virginia Elizabeth Harness \\ A Thesis Presented to the Faculty of \\ the Department of Architectural History \\ of the School of Architecture, University of Virginia \\ In Partial Fulfillment of the Requirement for the Degree \\ Master of Architectural History
}

May 2014

Thesis Committee

Richard Guy Wilson, Chair

Sheila Crane

Louis Nelson 


\section{Table of Contents}

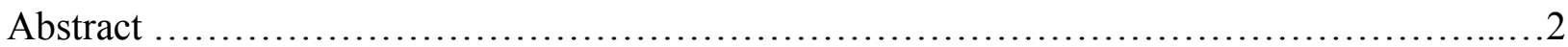

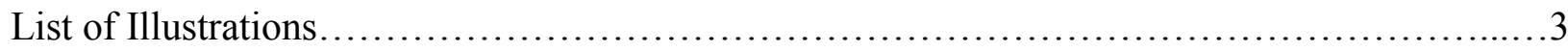

Acknowledgements.................................................................

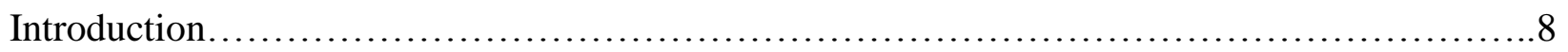

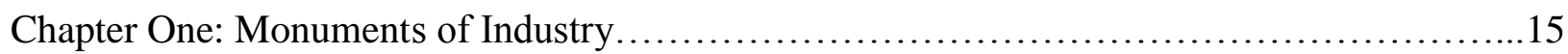

Chapter Two: Survivors of the Post-Industrial Age..................................... 35

Chapter Three: Selling Nostalgia................................................. 51

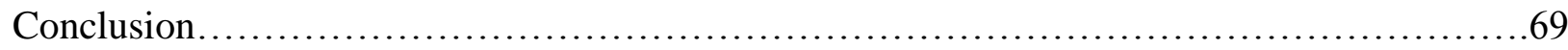

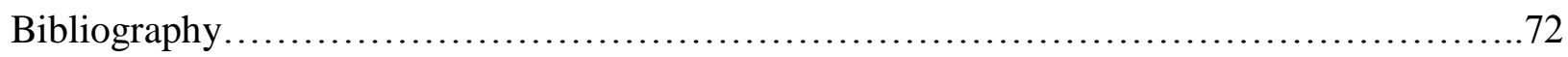

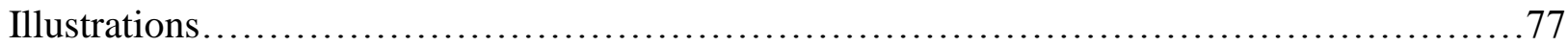




\begin{abstract}
This project charts the history of the Camden Warehouse and the Pratt Street Power Plant, two buildings constructed by railroad companies in Baltimore at the end of the nineteenth century. The warehouse, a product of the Baltimore \& Ohio Railroad, and the power plant, the central power station for the United Railway \& Electric Company, both stand as massive monuments to the industrial glory days of Baltimore. These buildings were erected when the power of the rail was unchallenged and Baltimore thrived as a center of industry and transportation. Unfortunately, their importance in Baltimore's history soon faded as urban decay set in and the automobile shoved aside the streetcar and the locomotive. For the better part of the twentieth century these buildings lingered in obscurity by Baltimore's Inner Harbor, until they at last found new purpose through adaptive reuse in the waning decades of the century. Over the last one hundred years, these buildings have transcended their industrial roots and come to serve as objects of nostalgia for Baltimoreans. Charting the history of these two structures through the industrial age, deindustrialization, and finally their redevelopment as adaptive reuse projects shows how the place of these buildings in Baltimore has shifted, turning them from monuments of industry into monuments of nostalgia. As part of the late twentieth century phenomena of heritage tourism, developers largely left the exterior integrity of these buildings intact the marketed them as links to the past. Ultimately, however, the extent to which these buildings offer visitors any substantial connection to their history, and the history of Baltimore, remains minimal.
\end{abstract}




\section{List of Illustrations}

$\underline{\text { Introduction }}$

Fig. i.1 Aerial view of Baltimore's Inner Harbor area with the Camden Warehouse (left) and Pratt Street Power Plant highlighted. Source: Google Earth, August 29, 2010.

Fig. i.2 Camden Warehouse from the intersection of S. Howard Street and W. Conway Street. Source: Virginia Harness, February 8, 2014, Baltimore, MD.

Fig. i.3 West façade of The Pratt Street Power Plant. Source: Virginia Harness, February 8, 2014, Baltimore, MD.

\section{Chapter One}

Fig. 1.1 G. Gould Presbury, A New and Accurate Map of Baltimore Town, 1780. The Maryland Historical Society. Source: Hayward, Architecture of Baltimore, 3.

Fig. 1.2 Camden Station of the Baltimore \& Ohio Railroad, c.1871. The B\&O Railroad Museum, Inc. Source: Hayward, Architecture of Baltimore, 164.

Fig. 1.3 James Stewart \& Company, Baltimore \& Ohio Railroad's terminal warehouse, 1905. James F. Hughes Company; collection of the National Building Museum.

Fig. 1.4 Baltimore's business district following the great fire of 1904. Maryland Historical Society. Source: Hayward, Architecture of Baltimore, 237.

Fig. 1.5 Italianate details on the front façade of the restored Camden Station as seen in 2014. Source: Virginia Harness, February 8, 2014, Baltimore, MD.

Fig. 1.6 Detail showing decorative brickwork on the Camden Warehouse. Source: Virginia Harness, February 8, 2014, Baltimore, MD.

Fig. 1.7 "Baltimore, Maryland." 1890. Sanborn Fire Insurance Maps, 1867-1970 - Maryland. Source: Sanborn-Perris Map Company Limited, Insurance Maps of Baltimore, Maryland Vol. 1, map, 14b.

Fig. 1.8 "Baltimore, Maryland." 1901. Sanborn Fire Insurance Maps, 1867-1970 - Maryland. Source: Sanborn-Perris Map Company Limited, Insurance Maps of Baltimore, Maryland Vol. 1, map, 11 .

Fig. 1.9 Camden Warehouse front façade in 2014. Source: Virginia Harness, February 8, 2014, Baltimore, MD.

Fig. 1.10 Camden Station, warehouse, partial west elevation. Historic American Buildings Survey, Library of Congress. Source: Hayward, The Architecture of Baltimore, 174. 
Fig. 1.11 Peter Liebhold. “Pratt Street Power Station,” Baltimore City, looking SW from Pratt St. December, 1982. Maryland Historical Trust. Source: National Register of Historic Places, Pratt Street Power Plant, Baltimore, Maryland, National Register \# 87000564.

Fig. 1.12 Sanborn map showing the northern portion of Pier Four in 1890. Source: SanbornPerris Map Company Limited, Insurance Maps of Baltimore, Maryland Vol. 1, map, $12 \mathrm{~b}$.

Fig. 1.13 Windows on the northern engine house of the Pratt Street Power Plant showing mansard roof and "x"-muntins on windows. Source: Virginia Harness, February 8, 2014, Baltimore, MD.

Fig. 1.14 Peter Liebhold."Pratt St. Power Station,” Baltimore City, looking SE from Pier 3. December, 1982. Maryland Historical Trust. Source: National Register of Historic Places, Pratt Street Power Plant, Baltimore, Maryland, National Register \# 87000564.

Fig. 1.15 Pratt Street Power Plant, early twentieth century. Source: Hayward, Architecture of Baltimore, 181.

Fig. 1.16 West façade of the south engine house of the Pratt Street Power Plant as seen today. It's original exterior is intact minus the modern Hard Rock Café signage. Source: Virginia Harness, February 8, 2014, Baltimore, MD.

Fig. 1.17 View over the harbor from Federal Hill following the 1904 fire. The Pratt Street Power Plant stands relatively unscathed compared to the surrounding city. Source: "Great Baltimore Fire of 1904." Maryland Digital Cultural Heritage Project, Enoch Pratt Free Library. Last modified 2004. <http://www.mdch.org/fire/\#>

Fig. 1.18 Pratt Street, early 1900s, with a view of the power plant belching smoke in the background. Source: Helton, Baltimore's Streetcars and Buses, 37.

\section{Chapter Two}

Fig. 2.1 Camden Warehouse c.1949, B\&O Museum Archives. Source: Harwood, Impossible Challenge, 196.

Fig. 2.2 Interior of Camden Warehouse during the construction of Camden Yards, showing the vast storage space inside. Source: "The Construction of Oriole Park at Camden Yards," url: $<$ http://countingbaseballs.mlblogs.com/2012/03/01/the-construction-of-oriole-park-at-camdenyards/>

Fig. 2.3 Carr's plan for Camden Yards. Source: C. Fraser Smith, "Plan would make bleak Camden yards a $\$ 170$ million living-working complex, ” The Baltimore Sun, May 23, 1979, A1.

Fig. 2.4 The warehouse in 1978, looking rundown and dirty. Source: "Mike's Railroad Page," <http://www.navpooh.com/camyards.html> 
Fig. 2.5 "Harbor Exchange" planned by developer Morton Macks. Source: Sandy Banisky, "Camden complex planned: Zoning requested for stores, offices in old warehouse," The Baltimore Sun, September 29, 1983, E1.

Fig. 2.6 Photograph showing the incorporation of the warehouse into the fabric of the stadium. Source: Virginia Harness, July 10, 2013, Baltimore, MD.

Fig. 2.7 Concept art for Six Flags urban theme park in the power plant by The Goddard Group. Source: "Baltimore Power Plant," The Goddard Group, url: $<$ http://www.garygoddard.com/entertainment-design/baltimore-power-plant/>

Fig 2.8 Interior lobby space of the Six Flags Power Plant in the 1980s. Source: "Baltimore Power Plant," The Goddard Group, url: <http://www.garygoddard.com/entertainment-design/baltimorepower-plant/>

Fig. 2.9 Exterior of the Six Flags version of the Power Plant. Source: "Baltimore Power Plant," The Goddard Group, url: <http://www.garygoddard.com/entertainment-design/baltimore-powerplant/>

Fig. 2.10 Panoramic view of a packed Oriole Park at Camden Yards. The Camden Warehouse looms large of right field in the background. Source: "Oriole Park at Camden Yards," url: <http://baltimore.orioles.mlb.com/bal/ballpark/>

Fig. 2.11 Aerial view of Oriole Park at Camden Yards designed by HOK (now Populous), showing red brick and arches of the new construction at right that mimic the architecture of the historic warehouse (left). Source: "Transforming Ballpark Design: Oriole Park at Camden Yards," url: <http://populous.com/project/oriole-park-at-camden-yards/>

Fig 2.12 The 3,000 gallon aquarium in Barnes \& Noble. Source: Virginia Harness, March 29, 2014, Baltimore, MD.

Fig. 2.13 A smokestack rises up through the levels of the Barnes \& Noble Bookstore in the central boiler house of the Pratt Street Power Plant. Source: Virginia Harness, March 29, 2014, Baltimore, MD.

Fig. 2.14 The interior workings of the escalator are exposed to shoppers at the Barnes \& Noble Bookstore, adding to the industrial feeling of the space. Source: Virginia Harness, March 29, 2014, Baltimore, MD.

\section{Chapter Three}

Fig. 3.1 A portion of the historic display above the magazine section in Barnes \& Noble in the Pratt Street Power Plant. Source: Virginia Harness, March 29, 2014, Baltimore, MD. 
Fig. 3.2 Continuation of the display in Barnes \& Noble, showing a historic photo and text that reads "The United Railway and Electric Company of Baltimore." Source: Virginia Harness, March 29, 2014, Baltimore, MD.

Fig. 3.3 Civil War Trails marker next to Camden Station. Source: Virginia Harness, February 8, 2014, Baltimore, MD.

Fig. 3.4 Maryland Historical Trust and Maryland State Highway Administration Marker to commemorate the railroad strike of 1877, put up next to Camden Station in 2013. Source: Virginia Harness, February 8, 2014, Baltimore, MD. 


\section{Acknowledgements}

I would like to thank the members of my thesis committee, Richard Guy Wilson, Sheila Crane, and Louis Nelson, for guiding me through the thesis process. I would also like to thank my dear friends Brooks Pendergast and Anna Perry, for giving me a place to sleep on my numerous trips to Baltimore. Finally, I must express my appreciation to my parents, Bryan and Leah Harness, for taking me to Baltimore for the first time almost twenty years ago and introducing me to the wonders of the Inner Harbor. 


\section{Introduction}

In his book Spaces of Hope, anthropologist and geographer David Harvey describes Baltimore as “...for the most part, a mess. Not the kind of enchanting mess that makes cities such interesting places to explore, but an awful mess."1 The criticism Harvey levels is not unfair, and it applies just as much to the city's built environment as to its socio-economic state. Still, among the abandoned housing stock and run-down storefronts there are survivors, buildings that stand as reminders of Baltimore's heyday as an American industrial power. These old relics of industry are scattered across the city, but two industrial structures, both built within sight of the Inner Harbor (Fig. i.1), stand apart from the others: the Camden Warehouse (Fig. i.2) and the Pratt Street Power Plant (Fig. i.3). These two buildings were constructed on a massive scale befitting the metropolis John Quincy Adams nicknamed “The Monumental City” in 1827. Though Quincy referred to the many cathedrals and monuments of early nineteenth century Baltimore, his moniker for the city has stood the test of time as Baltimore is now dotted with many great edifices that stand as monuments to its industrial past. ${ }^{2}$ Charting the history of the Camden Warehouse and the Pratt Street Power Plant through the height of Baltimore's industrial age, to the city's postwar deindustrialization, and finally to the adaptive reuse of both structures in the waning years of the twentieth century, will show how these two buildings evolved in the minds of Baltimoreans from monuments of industry into monuments of nostalgia.

Over the last decade, Baltimore reappeared in popular culture through the critically acclaimed HBO series The Wire. Created by former Baltimore Sun reporter David Simon, the series focuses primarily on the many problems that face Baltimore: such as drugs, corruption,

\footnotetext{
${ }^{1}$ David Harvey, Spaces of Hope (Berkeley and Los Angeles: University of California Press, 2000), 133.

2 Erin Donovan, "Nostalgia and Tourism: Camden Yards in Baltimore," in Myth, Memory, and the Making of the American Landscape, ed. Paul A. Shackel (Gainesville: University Press of Florida, 2001), 227.
} 
and failing schools. ${ }^{3}$ Problems compounded by the fact that Baltimore's violent crime rate continues to be one of the highest in the country. In the 2011 FBI Uniform Crime Report, the violent crime rate nationwide per 100,000 residents was 386.3. Baltimore City's crime rate stood at 1417.4 per 100,000 , nearly quadruple the national average. ${ }^{4}$ But Baltimore is much more than its drug trade or its crime rate. In recent years, the city has made a concerted effort to reinvent itself, and change its image. One of the key factors in that shift is the adaptive reuse and preservation of old industrial sites; places that can move Baltimore into the future while still honoring its past.

Sadly, historians have largely neglected Baltimore, especially in recent years. Architectural historian Mary Ellen Hayward stands as a rare example of a scholar devoted to telling the history of Baltimore through built forms. Hayward wrote two books on Baltimore's row houses and co-edited The Architecture of Baltimore: An Illustrated History. This volume provides a thorough survey of Baltimore's entire architectural history, from its founding in the 1750s through the end of the twentieth century. The scope of the book is admittedly quite large, but even so it provides excellent context for different periods of Baltimore's architectural development, including the city's industrial age. ${ }^{5}$

Industrial buildings are also often given short shrift in the realm of architectural history, especially those structures that fall outside of the mill and factory model. One of the most comprehensive scholarly works on industrial architecture is The Works: Industrial Architecture

\footnotetext{
${ }^{3}$ David Simon, The Wire (Baltimore: Home Box Office, 2002-2008).

${ }^{4}$ Federal Bureau of Investigation, "FBI Uniform Crime Report 2011: Violent Crime," accessed December 11, 2012, url: <http://www.fbi.gov/about-us/cjis/ucr/crime-in-the-u.s/2011/crime-in-the-u.s.-2011/violent-crime/violentcrime>

${ }^{5}$ Mary Ellen Hayward and Frank R. Shivers, Jr., eds., The Architecture of Baltimore: An Illustrated History (Baltimore and London: The Johns Hopkins University Press, 2004).
} 
of the United States by Betsy Hunter Bradley. Where many books on industrial architecture are written around case studies or surveys, Bradley delves into the why and how of industrial architecture. She largely eschews traditional architectural analysis in favor of attempting to understand industrial buildings through the eyes of the engineer. Bradley relates the design of these buildings to their function, efficiency, and the public image of the companies that built them, all factors that were at play during the period of construction for both the Camden Warehouse and the Pratt Street Power Plant. ${ }^{6}$

Waterfronts in Post-Industrial Cities, edited by Richard Marshall, takes a leap forward from the portion of industrial history covered by The Works. Marshall's collection of essays provides commentary on various efforts across the globe to transform deindustrialized port cities from depressed reliquaries into vibrant communities. Special attention is paid to Baltimore's Inner Harbor area redevelopment, which eventually encompassed the Pratt Street Power Plant and, on its absolute western edge, the Camden Warehouse. Of particular note here are the essays by Martin L. Millspaugh and Barry Shaw, both of which deal directly with Baltimore and speak to the positive impacts of the redevelopment. Millspaugh also highlights Baltimore's Inner Harbor as an example to other struggling urban environments, noting its award winning design and financial success. ${ }^{7}$

The story of Baltimore's harbor side renewal and the adaptive reuse of the warehouse and the power plant is, however, far more complex than a book such as Waterfronts might lead you to think. The trend of adaptive reuse and Baltimore's longing to reach out and touch, however

\footnotetext{
${ }^{6}$ Betsy Hunter Bradley, The Works: The Industrial Architecture of the United States (New York and Oxford: Oxford University Press, 1999).

${ }^{7}$ Richard Marshall, ed., Waterfronts in Post-Industrial Cities (London and New York: Spoon Press, 2001).
} 
fleetingly, its industrial glory days is a reflection of the city's nostalgia. The subject of nostalgia transcends disciplines and permeates many aspects of social life. One of the most frequently cited works on the phenomena is The Future of Nostalgia by Svetlana Boym. Boym gives a brief account of the history of nostalgia and its explosion onto the cultural scene beginning in the late seventeenth century. More importantly, however, Boym identifies "restorative nostalgia," a particular variation of nostalgia where a longing for what once was is expressed through the reconstruction of the past. Boym's explanation of nostalgia and the way it affects society provide an important framework for the national trends of adaptive reuse and historicism in American architecture. $^{8}$

Nostalgia's impact on the built environment is critiqued quite severely by Michael Sorkin's Variations on a Theme Park: The New American City and the End of Public Space, in which Sorkin brings together a series of essays chronicling the odd direction the American city has taken in the last twenty to thirty years. The book covers a number of topics, but the two essays of primary interest here are Sorkin's own introduction to the work and M. Christine Boyer's chapter titled “Cities for Sale: Merchandising History at South Street Seaport.” Sorkin lays out the characteristics that define his "new city" while Boyer takes on the faux historical effect of a waterfront redevelopment project in New York City in the same vein as Baltimore's own Inner Harbor. Sorkin and Boyer do not hold back as they dig into the simulated world created through the inattentive repurposing and sanitization of the history of American cities. Their assessment is often on the mark, though at times swerves into the melodramatic and

\footnotetext{
${ }^{8}$ Svetlana Boym, The Future of Nostalgia (New York: Basic Books, 2001).
} 
readers should be careful not to be too quick to apply broad generalizations about the effects of adaptive reuse. $^{9}$

Finally, Daniel Bluestone's article "Tobacco Row" offers both a supporting argument and a kind of foil to the harsh words of Sorkin and Boyer. In the article, Bluestone discusses the transformation of Richmond, Virginia's tobacco warehouses into high-end apartment buildings. Like Sorkin and Boyer, he finds that result of the project in Richmond is too general and does little to truly engage with the history of the buildings. However, Bluestone also offers up the beginnings of an alternative, where developers might make a more concerted effort to incorporate history into the design of reuse projects. He challenges the obsession with the external appearance of historic structures and calls for a change in preservation thinking that more carefully considers how the use of historic buildings interprets and engages the stories of the past. ${ }^{10}$ This idea has important implications not only for easing the nostalgic ennui of the collective American psyche, but for bringing the citizens of places like Baltimore back into the fold by integrating history into the city's tourist destinations. Baltimore is troubled by many problems without easy solutions, but the history of the buildings that have endured, buildings like the Camden Warehouse and the Pratt Street Power Plant, can serve as a point of unification in a city divided by race, class, and geography.

Less than a century ago, Baltimore was one of the largest and most important cities in the country. With an ideal location on the Chesapeake Bay and easy access to rivers and falls, Baltimore quickly became an excellent site for the water-fuelled early years of the Industrial

\footnotetext{
${ }_{9}^{9}$ Michael Sorkin, ed., Variations on a Theme Park: The New American City and the End of Public Space (New York: Hill \& Wang, 1992).

${ }^{10}$ Daniel Bluestone, "Tobacco Row: Heritage, Environment, and Adaptive Reuse in Richmond, Virginia." Change Over Time, vol. 2, no. 2 (2012).
} 
Revolution and continued to be an industrial power well into the twentieth century. Baltimore also pioneered rail transportation in America, with the first regular railroad service in the United States, the Baltimore \& Ohio, going into operation in 1830 . The city was also an early player in streetcar transportation systems and the electrification of local rails. When rail transportation was still in its nascent stages, companies often struggled financially and put little effort into the architectural infrastructure associated with rail travel. However, around mid-century, technology and profits stabilized enough for railroad companies to concentrate on their public image, and with the consolidation of Baltimore's streetcar companies at the end of the century, the localized rail companies followed suit. ${ }^{11}$

It was into this context of thriving industry and abundant mobility that both the Camden Warehouse and Pratt Street Power Plant first come into existence. The first chapter of this thesis will examine how and why these two industrial buildings were erected at the turn of the century. Understanding these structures as-built also requires a cursory understanding of the companies that paid for their construction. The chapter therefore briefly explores the history of both the Baltimore \& Ohio Railroad and the United Railway \& Electric Company, the companies that built the Camden Warehouse and the Pratt Street Power Plant, respectively. The conclusion of the chapter is devoted to the likely architect of both buildings and explains the impact his personal style, design pedigree, and previous experience may have had on the final products. The purpose of gathering together these myriad details is to show that the Camden Warehouse and the Pratt Street Power Plant were designed and built as symbols for the powerful companies that financed their creation and utilized them for the purposes of industry. Both structures went

\footnotetext{
${ }^{11}$ Hayward, Architecture of Baltimore, 161-164, 180-182.
} 
beyond the purely practical buildings of the early years of the Industrial Revolution and became monuments of the might of industry at the turn-of-the-century.

The second chapter follows the storylines of the Pratt Street Power Plant and the Camden Warehouse through the upheavals of deindustrialization and early downtown redevelopment in Baltimore. This period, spanning the middle portion of the twentieth century, was a time when the fates of both these buildings was increasingly uncertain. This chapter examines the role of rail transportation as a precursor to modern mobility and the ways in which changes in transportation technology not only allowed for the development of these two buildings at the end of the nineteenth century, but eventually ended up causing the demise of the companies that created them in the twentieth century. The chapter chronicles the journey of each building through sales and company mergers before looking into the early proposals for their reuse beginning in the 1960s and 1970s. The fate of the warehouse and power plant in this period mirrored that of the city of Baltimore, as it struggled to regain its footing in the wake of deindustrialization.

Finally, the third chapter tackles not only the successful reuse projects that were eventually developed for both the warehouse and the power plant, but also delves into the larger societal forces at work in adaptive reuse. Nostalgia plays a central role in this portion of the paper, as it is a primary force driving the reuse of industrial buildings in former 'Rust Belt' cities like Baltimore. The impact of nostalgia is keenly felt in Baltimore, where the city went from industrial powerhouse to industrial wasteland within the span of a generation. Baltimore was cut off fairly suddenly from the relative prosperity it had enjoyed in the nineteenth and early twentieth century, creating an environment ripe for nostalgia and a return to the industrial glory days still present in the memories of many Baltimoreans by the late twentieth century. 
Furthermore, the effect of this particular form of preservation is studied, with a view not only to the problems created by adaptive reuse, but the ways in which it might be improved. discussion of the place of the Pratt Street Power Plant and the Camden Warehouse in Baltimore today and reiterate the idea that both buildings have not only transformed from the industrial to the nostalgic, but also have the potential to transcend either category.

\section{Chapter One: Monuments of Industry}

$\underline{\text { Industry Makes its Mark }}$

In the years leading up to the turn of the century, Baltimore was a rapidly growing city fuelled by a slew of emerging industries and the rise of the Baltimore \& Ohio Railroad. The city's population increased twenty-fold between 1800 and 1900. The Basin of the Patapsco River, now known as the Inner Harbor, was Baltimore's lifeline to the world in the opening decades of the $19^{\text {th }}$ century. The ideal positioning of the city on a natural harbor with access to fast flowing streams and local rivers helped to turn Baltimore into a center of industry. As the century progressed, Baltimore looked to extend its transportation capabilities with the incorporation of the Baltimore \& Ohio Railroad in 1827. Between the American Revolution and the Civil War, Baltimore went from being a little town on the Chesapeake to a thriving bayside metropolis (Fig. 1.1). ${ }^{12}$

By mid-century, Baltimore was an industrial power on par with major urban centers such as Philadelphia and New York City. As industry rose to dominate Baltimore, it began to make its mark on the city's built environment. Early in the century the primary industrial buildings in the Baltimore area were water-powered mills. As the Industrial Revolution got underway, other

\footnotetext{
12 Hayward, Architecture of Baltimore, 150-152.
} 
structures began to appear in the city. Factories, warehouses, and depots appeared with greater frequency in the cityscape and brought with them other changes to the urban fabric. ${ }^{13}$ Bridges, tunnels, miles of train track and the advent of electricity altered urban infrastructure, and rows of new houses went up to shelter workers, many newly arrived from famine and war ravaged Europe. $^{14}$

The rise of industry in Baltimore was as a ripple in a pond, with its influence spreading out across the city. At the center of this ripple were the industrial buildings themselves, for they not only housed the machines and workers who made production possible, but they were also a prominent part of the public image of industrial work. Years before the age of the 'ideal factory' championed by men like Walter Gropius and his Bauhaus followers, these factories and warehouses tended to be purely practical in design: “...whatever their differences in use, shape, and age, Baltimore's industrial structures - generally, and especially early on - shared one common feature: They were designed strictly to enclose a production process in the most effective and efficient way possible." 15 It was not until the second half of the century that aesthetic considerations began to play a role in the creation of industrial buildings.

The look and feel of industrial complexes became important as companies attempted to present their success and power in overtly visual terms. This was especially true for the railroads, where the public had greater access to the industry as passengers. Initially, concern for appearance was restricted to the most public of railroad buildings: the passenger terminal. Architects were employed, designs were selected and stylized train stations began to appear on

\footnotetext{
13 Ibid.

${ }^{14}$ Mary Ellen Hayward, Alley Houses: Homes for Working People Since the 1780s (Baltimore: Johns Hopkins University Press, 2008), 8-10.

${ }^{15}$ Hayward, Architecture of Baltimore, 153,
} 
the Baltimore landscape. ${ }^{16}$ Additionally, the advent of the railroad was soon followed by the more localized streetcar, an altogether different kind of rail system that would also have a dramatic impact on the American landscape and how Americans lived within it. The railroads, of every length and capacity, brought “...the Industrial Revolution to within easy reach of virtually everyone," and fundamentally altered humankind's relationship to space and time. ${ }^{17}$ It was the dawn of modern mobility, and the buildings of rail industries were essential players in the emergence of this new age of transportation.

\section{Building the Camden Warehouse}

For most of the $19^{\text {th }}$ century, the Baltimore \& Ohio Railroad Company stood at the helm of rail transportation in and out of Baltimore. It was a central part of the city, not only in terms of economics, but in terms of identity. In the words of John P. Haney of the Baltimore and Ohio Railroad Museum: "The B\&O was, more so than most of its competitors, a home-grown project that reflected the needs, aspirations and limitations of its public and private sector parents. To be sure, it touched the lives of millions of people throughout the country, but...its heart and soul were in Baltimore," a testament to the long history of the railroad and its strong roots in the city. ${ }^{18}$

Established in 1827, it was the first railroad company formed in Baltimore, a year ahead of the Baltimore \& Susquehanna. The company could claim the distinction of having "the first regular railroad service in the United States" by 1830, albeit with passenger cars drawn by horses

\footnotetext{
${ }^{16}$ Hayward, Architecture of Baltimore, 161-163.

17 John P. Hankey, "Introduction," in Impossible Challenge: The Baltimore and Ohio Railroad in Maryland, Herbert H. Harwood (Baltimore: Barnard, Roberts and Company, Inc., 1979).

18 Ibid.
} 
rather than locomotives. ${ }^{19}$ A year later a steam locomotive was in operation on the line between Baltimore and Frederick. Money was often tight, and constant changes in technology made building the railroad out to the Ohio River a lengthy and complex task. The Baltimore \& Ohio employed enormous workforces to dig, fill, and level the earth as the tracks marched onward towards the Ohio. It took two years to finish the first twenty-six miles. ${ }^{20}$ Work progressed so slowly that the railroad did not succeed in reaching the Ohio River until 1853, over a quartercentury after the company's original charter was granted. ${ }^{21}$

In the 1850 s, the financial instability that marked the early years of the railroad came to an end and railroad companies became real economic forces. In this same period, a new focus was placed on the impression the railroad made on passengers with its terminals and depots. Other railroads in the city outpaced the Baltimore \& Ohio in the construction of high-style terminals, leaving the company scrambling to catch up. In 1852 they purchased a piece of land to the west of the Basin, encompassing four blocks between Howard and Eutaw streets. Construction on Camden Station (Fig. 1.2) began four years later, with its original design by Niernsee \& Nielsen and under the supervision of architect Joseph Kemp. ${ }^{22}$ The company hoped the high-style of Camden Station, which still stands adjacent to what is now Oriole Park at Camden Yards, would “...rival contemporary London stations...” with its Italianate design and impressive scale. The desire to overwhelm the skyline was so great that the central tower

\footnotetext{
${ }^{19}$ Herbert H. Harwood, Impossible Challenge: The Baltimore and Ohio Railroad in Maryland (Baltimore: Barnard, Roberts and Company, Inc., 1979), 21.

${ }^{20}$ Mary Ellen Hayward and Charles Belfoure, The Baltimore Rowhouse (New York: Princeton Architectural Press, 199), 72-73.

${ }^{21}$ Harwood, Impossible Challenge, 50.

22 Ibid., 57-59.
} 
originally stood at 180 feet, a height that was deemed unsafe after it was built and had to be reduced. $^{23}$

Towards the end of the century, the interest in building architect designed industrial structures extended beyond the publicly visible passenger terminals and into the more practical side of industrial processes. The overwhelmingly large central tower of the Camden Station was designed to dwarf every other building in Baltimore, and this obsession with scale extended to other buildings as well. Two of the largest and most impressive industrial structures erected in Baltimore during this period were a power plant and a warehouse. Neither served a very glamorous function, but they were nevertheless designed to impress, both with size and style.

The larger of these structures was the Camden Warehouse built by the Baltimore \& Ohio Railroad Company. Between 1899 and 1904 the warehouse was constructed just to the south of the ornate Camden Station (Fig. 1.3). Eight stories high, 50 feet wide, and an astonishing 1,100 feet long, the Camden Warehouse was one of the largest buildings ever to grace the American landscape, let alone the city of Baltimore. ${ }^{24}$ It was, in the words of one Baltimore Sun reporter: “...one of the largest and most important commercial structures in the country..." and cost the Baltimore \& Ohio Railroad a total of $\$ 500,000$ in construction costs by the time its final addition was completed. ${ }^{25}$ In its finished state, the warehouse's interior made an impressive 430,000 square feet available for storage purposes, equivalent to one thousand boxcars. ${ }^{26}$

\footnotetext{
${ }^{23}$ Hayward, Architecture of Baltimore, 163.

24 “THE B. \& O. TO BUILD: Addition to Terminal Warehouse at Camden Station," The Baltimore Sun, August 2, 1904, 7, accessed February 7, 2014 via ProQuest Historical Newspapers.

25 "CAMDEN STATION WAREHOUSE: Contract For The Building Awarded to Henry Smith \& Sons - A Great Structure," The Baltimore Sun, January 11, 1899, 10, accessed February 7, 2014 via ProQuest Historical Newspapers.

${ }^{26}$ Hayward, Architecture of Baltimore, 173.
} 
The scope of the Camden Warehouse was driven not only by the desire to create the largest building in the city, but also by the fire that wreaked havoc on Baltimore at the start of 1904. In February of that year, a major portion of the commercial center of downtown was engulfed in flames and utterly destroyed (Fig. 1.4). The fire forced the Baltimore \& Ohio Railroad Company to squeeze more of its operations into the Camden Yards complex, which survived the raging inferno. Unfortunately for the Baltimore \& Ohio, their company headquarters at the corner of Baltimore and Calvert Streets was not so lucky. The extension of the warehouse quickly became a necessity following the fire, as portions of the warehouse were taken over for office space and file storage after headquarters was destroyed. ${ }^{27}$ By 1905 a five-story office building had been added to the warehouse, solving the space issues created by the fire, but also resulting in the destruction of part of Camden Station.

The Camden Warehouse had to be more than a utilitarian structure. While it was touted for its holding capacity, the building was also a part of the larger railroad complex at Camden Yards. As such, it was a highly visible structure and the Baltimore \& Ohio didn't want their utilitarian warehouse to be an industrial eyesore next to the ornate grandeur of the older Camden Station (Fig. 1.5). The warehouse, though built several decades later and with a decidedly different purpose to fulfill, therefore self-consciously echoed the architectural language established by the construction of the passenger terminal. In keeping with this, the warehouse featured decorative elements that served no function other than to increase the aesthetic quality of the exterior, such as recessed arches and decorative brickwork (Fig. 1.6).

27 “THE B. \& O. TO BUILD,” The Baltimore Sun, August 2, 1904, 7. 
Prior to the building of the massive warehouse, the site was occupied by the freight sheds of the Baltimore \& Ohio, with the only designated warehouse on the Camden Yards property being the iron clad express warehouse fronting S. Howard Street (Fig. 1.7). ${ }^{28}$ That was the state of things in 1890 , but ten years later the $\mathrm{B} \& \mathrm{O}$ required more substantial capacity at the Camden site. In its original incarnation the warehouse stretched almost the entire four blocks of the B\&O’s property. It was connected to Camden Station by a stone office building (Fig. 1.8), which survived into the 1990s but was taken down during the construction of Oriole Park. ${ }^{29}$ The physical connection of Camden Station with the warehouse made it clear that this was not just a practical building but a part of one of the largest and most important terminals of the Baltimore \& Ohio Railroad.

The warehouse was also brought into visual harmony with the rest of Camden Yards through its architectural language. Rusticated stone forms the ground floor of the warehouse, with seven floors rising above it in five-course common bond brick and additional ornamentation on the cornice and stringcourses. The warehouse is designed with both horizontal and vertical breaks. Vertically the building is divided into four sections on the exterior, with rusticated stone at the base, then the second floor with a row of alternating arched recesses and windows. The third through sixth floors follow the same pattern as the first, but are differentiated from it by a granite stringcourse and the presence of elongated recessed arches that loop around each set of

\footnotetext{
${ }^{28}$ Sanborn-Perris Map Company Limited, Insurance Maps of Baltimore, Maryland Vol. 1, map (New York: The Sanborn-Perris Map Co. Limited , 1890), 14b, accessed February 18, 2014 via ProQuest Digital Sanborn Maps, url:

<http://sanborn.umi.com. proxy.its.virginia.edu/image/view?state=md\&reelid=reel01\&lcid=3573\&imagename=00 032\&mapname=Baltimore\%201890\%20vo;I.\%201,\%20Sheet\%2014_b\&CCSI=302n>

${ }^{29}$ Sanborn-Perris Map Company Limited, Insurance Maps of Baltimore, Maryland Vol. 1, map (New York: The Sanborn-Perris Map Co. Limited , 1901), 11, accessed February 18, 2014 via ProQuest Digital Sanborn Maps, url: <http://sanborn.umi.com. proxy.its.virginia.edu/image/view?state=md\&reelid=reel02\&lcid=3573\&imagename $=00$ 023\&mapname=Baltimore\%201901-1902\%20vol.\%201,\%201901,\%20Sheet\%2011\&CCSI=302n>.
} 
windows. These long arches serve to break up the enormous length of the façade facing S. Eutaw and S. Howard Streets (Fig. 1.9)

The first six floors of the building are topped with another granite stringcourse and then the ornamental brickwork of the top two floors. With the seventh story the windows decrease in size and lose their arch, while the eighth floor windows are reduced in size to fit the narrower space granted to the top floor (Fig. 1.10). The interior of the warehouse was divided into six sections by brick firewalls, an astute precaution given the history of fire in the city. ${ }^{30}$ Elevators, run primarily on hydraulics (with the exception of warehouse $\mathrm{B}$, whose elevators ran on electric motors) made it easy to vertically transverse the buildings eight floors. ${ }^{31}$

According to Mary Ellen Hayward, the building “...symbolized the high tide of railroads at the turn of the century, when they hauled virtually all of the nation's intercity freight." 32 Despite the tenuous financial situation of the Baltimore \& Ohio during this period, the men responsible for the company were very much aware of their image within the city. The warehouse, with its overwhelming size, was an unmistakable part of the highly cultivated public image the railroad company presented in its home base of Baltimore.

\section{Building the Pratt Street Power Plant}

While the Baltimore \& Ohio was certainly an important part of the Baltimore economy, the local populace was much more likely to have daily interaction with the city's streetcar rail lines. Prior to the invention of the automobile, which would prove to be the ultimate shaper of space in the twentieth century, American citizens relied on local rail lines to take them around

\footnotetext{
${ }^{30}$ Hayward, Architecture of Baltimore, 173.

${ }^{31}$ Sanborn-Perris Map Company Limited, Insurance Maps of Baltimore, Maryland Vol. 1, map, 11.

32 Hayward, Architecture of Baltimore, 174.
} 
the city and out to the growing suburbs. At the local level, the United Railways \& Electric Company provided streetcar service for the Baltimore Metropolitan area at the beginning of the twentieth century. The rise of the United Railways \& Electric Company was a sign of the city's progress. Before consolidation, Baltimore had suffered from a lack of centralization when it came to mass transit:

The deplorable condition of city transportation in Baltimore before 1899 came about due to competition among the many existing lines. On March 4, 1889 these independent companies joined hands and became the United Railways \& Electric Company. To supply electrical energy for the street cars, the numerous small generating plants were dispersed and a large power plant was established on Pratt Street. ${ }^{33}$

The plant referred to above is commonly known as the Pier Four or Pratt Street Power Plant. Constructed in three phases between 1892 and 1904, it stands in a prominent position on the northern edge of the Inner Harbor (Fig. 1.11). Like the Camden Warehouse, the Pratt Street Power Plant was one of the largest buildings of its kind at the time of its construction. ${ }^{34}$ The advent of electricity and the reorganization of the city's transit system were marks of modernization in Baltimore at the turn of the century. As the central plant for electricity in the city, the Pratt Street Power Plant was a physical manifestation of modern Baltimore.

In 1890, the future home of the Pratt Street Power Plant was just another pier in the harbor basin. Pier Four was wooden construction, lined to the west by O'Donnell's Wharf and to the east by Dugan's Wharf. The State Tobacco Warehouse dominated the end of the pier, while the landward side was a cluster of much smaller warehouses, oyster packing, and the J. Beatty Steam Biscuit Bakery. Pier Four also proved to be an ideal location for power plants early on, for

\footnotetext{
${ }^{33}$ George M. Lapoint, "The history and development of the Pratt Street Power Plant of the Baltimore Consolidated Gas Electric Light and Power Company," Records of Phi Mu, Special Collections, University of Maryland Libraries, 1925.

34 "New Power Plant for Baltimore: Special to The New York Times," The New York Times, November 3, 1904, 10, accessed July 7, 2014 via ProQuest Historical Newspapers.
} 
nestled in the midst of these buildings was the Electric Light Works (Fig. 1.12). ${ }^{35}$ Two years later the Baltimore Sun reported that the City and Suburban Railway Company had secured property on the pier and planned to erect their new power station there. Situating power stations on the pier was convenient for a number of reasons. Most streetcar lines passed by the Pratt Street location, and the proximity to water meant that the power plant would not only have a ready supply of water for condensation, but also ensured that coal could by easily delivered (by means of scows) directly to the plant. ${ }^{36}$

Consolidation radically changed the streetcar experience in Baltimore. It was a controversial idea in the years immediately preceding the formation of the United Railway \& Electric Company. Citizens feared losing local control of the streetcar system to a corporation from another city, but there was also clear recognition that consolidation could be a great help to the city's complicated transit system:

It is said that should the consolidation take place the companies would receive new stock in proportion to their business and advantages. Nor would the company, it is said, be anything but a good to the city. In the first place, a complete system of transfers would be forthcoming. The streets of principal traffic would have a steady stream of electric cars, grades would be mounted at the rate of nine miles an hour by cable lines, and quick travel would be the result. Schemes for real estate dealing and the development of suburbs are also said to be in the minds of the consolidators. ${ }^{37}$

\footnotetext{
${ }^{35}$ Sanborn-Perris Map Company Limited, Insurance Maps of Baltimore, Maryland Vol. 1, map (New York: The Sanborn-Perris Map Co. Limited , 1890), 12b, accessed February 18, 2014 via ProQuest Digital Sanborn Maps, url:

<http://sanborn.umi.com.proxy.its.virginia.edu/sanborn/image/view?state=md\&reelid=reel01\&lcid=3573\&imagen ame $=00028 \&$ mapname $=$ Baltimore $+1890+$ vol. $+1 \% 2 C+$ Sheet+12_b\&zoomName=100\&zoomValue $=1 \& z o o m N e w N a$ me $=75 \&$ centerX=568\&centerY=652\&viewportWidth=925\&viewportHeight=700\&CCSI=302n\&clickType=zoom \&zoo mLevelPicker $=75>$

36 "A GREAT POWER-HOUSE: Property Purchased by City and Suburban Railway," The Baltimore Sun, November 2, 1892, 8, accessed February 7, 2014 via ProQuest Historical Newspapers.

37 "A BIG SCHEME IF TRUE: Speculative Rumors About the Possibilities of Railway Consolidation," The Baltimore Sun, February 10, 1888, 6, accessed February 7, 2014 via ProQuest Historical Newspapers.
} 
Ultimately, the positive factors of consolidation outweighed the reservations of the citizenry, and the United Railway \& Electric Company was created. With the consolidation of the streetcars and electric power, the area of the pier devoted to the production of electricity was significantly increased. By 1902, two of the power plant's three sections were complete, and within two years the entire complex was finished, a monolithic creation sitting in the midst of the Basin's six piers.

The three sections were built in different years, by two different companies, and at least as many different architects and contractors. Thus, they differ quite dramatically from one another upon close inspection. The oldest portion of the power plant is closest to Pratt Street itself, where the pier meets land. This section of the power plant was, as mentioned above, a structure commissioned by the City and Suburban Company and erected in 1893 at an estimated cost of half a million dollars. It was the intent of the company's owners that the power plant "will have a greater capacity, will be larger and more modern in design and machinery than any similar plant in the country." ${ }^{38}$ The plant they constructed was of considerable size, with brick construction laid out in the slightly old-fashioned but expensive Flemish bond pattern. The multistory windows were framed in a stripped down Classical style, with muntins laid in an X pattern (Fig. 1.13).

With the streetcar companies were consolidated under the new United Railway \& Electric Company at the end of the nineteenth century, the UR\&E decided to expand the existing power plant on Pier Four and make it the central plant for Baltimore. They increased the size of the plant by adding two additional buildings, the central boiler house and the southern engine house.

38 "A GREAT POWER-HOUSE," The Baltimore Sun, November 2, 1892, 8. 
The west façade of the boiler house was altered during the $1990 \mathrm{~s}$, but as originally built it consisted of five bays created by large brick pilasters above a rough stone basement level. The pilasters are caped in narrow bands and a brick molding reminiscent of tradition capitals. The attic level is decorated with corbelled brickwork and stepped gable. The windows are framed by granite bands below and splayed brick flat arches above (Fig. 1.14). In the plant's working days most of the boiler house was hidden, save for the four enormous self-supporting smoke stacks that capped its roofline (Fig. 1.15). The design of the southern engine house continued the same architectural vocabulary, with window panes divided into a " $\mathrm{x}$ " over cross pattern similar, though slightly different, from the panes of the two preceding structures. It is also divided into bays by pilasters, and has a rough stone base. The common bond brick and stepped parapet echo the central boiler house (Fig. 1.16). ${ }^{39}$ The ultimate effect was an industrial building complex of massive scale but with many nods to the tradition of Classical architecture. According to Sherry Olson, "The new powerhouse of United Electric on Pratt Street in the inner harbor...was a massive and even elegant symbol of the new technology and the new corporate monopoly."40 The simplified Classical details of the plant lent it the elegance of which Olson writes, and also served to connect the plant with traditional thinking even as it's very function was to propel Baltimore into the future.

For all its artistic merit and modern equipment, however, the Pratt Street Power Plant faced a number of challenges during its time under the United Railway \& Electric Company. In

\footnotetext{
${ }^{39}$ National Register of Historic Places, Pratt Street Power Plant, Baltimore, Maryland, National Register \# 87000564, accessed April 25, 2014, via the Maryland Inventory of Historic Properties, url:

<http://www.mdihp.net/dsp_search.cfm?search=address\&id=40226\&viewer=true\&updated=Y\&criteria1=A\&criter ia2=AL>

${ }^{40}$ Sherry L. Olson, Baltimore: The Building of an American City (Baltimore: The Johns Hopkins University Press, 1980), 238.
} 
1906, a "mysterious accident" at the plant "tied up every streetcar in Baltimore." ${ }^{41}$ When the central plant faltered, the ramifications were felt widely across the city. Suburban commuters were trapped downtown, electric lights went dark, telegraph lines were silent, and elevators ceased operation. The freezing of movement in the city caused by the incident in 1906 was likened to the paralysis experienced following the Great Fire in 1904. The UR\&E brought in an expert from New York to examine the plant and make recommendations for preventing such trouble in the future, a move which shows just how key the central plant was to the smooth operation of electricity in Baltimore and the continued success of the company. ${ }^{42}$

Though the plant was overburdened in this period by the intense demand for streetcar transit, the company's commitment to the plant and to the quality of their service remained high: “It was again reiterated that the company's officials will spare no expense to bring this central plant to a condition of perfect reliability. It is their purpose to serve the public, they say, with the least inconvenience, and to give a car service second to none. ${ }^{, 43}$ However, despite the expert opinion from New York and the financial commitment of the company's executives, trouble continued to plague the Pratt Street Power Plant. Less than a year after the outage, another major setback hit the plant.

In February of 1907, the oversight of the New York expert, Mr. Stillwell, became a challenge rather than a help to the company. Claiming to have been abused by a Stillwell employee, 25 boiler room workers walked out, leaving the plant utterly in the lurch. The walk-

\footnotetext{
41 "STREET CARS STOPPED: Accident At Power House Causes All-Night Tie-Up," The Baltimore Sun, April 29, 1906, 7, accessed February 7, 2014 via ProQuest Historical Newspapers.

42 "TO PREVENT “TIE-UPS" New York Experts Examine Pratt Street Power House," The Baltimore Sun, August 15, 1906, 14, accessed February 7, 2014 via ProQuest Historical Newspapers.

43 “IMPROVING POWER STATION: Experts Give Suggestions And Work Will Begin At Once," The Baltimore Sun, August 18, 1906, 7, accessed February 14, 2014 via ProQuest Historical Newspapers.
} 
out came right at rush hour, shutting down the lines from 5:00 PM to 6:30 PM and leaving passengers to wait or walk home in the harsh winter weather. The company kept outlying lines running with auxiliary plants, but without the central lines in operation travel was severely limited:

So long as the cars served from [the auxiliary] stations were operated by the current they furnished there was no interruption to traffic. As soon as they left those circuits and tried to take up that from the Pratt street power-house they became stalled like the rest. That occurred in all the central portions of the city, so that no passenger from one section could reach another so long as the Pratt street plant was out of commission. ${ }^{44}$

The men who quit (they were restored to their positions the following day) claimed to have been overworked and verbally abused by an overseer from Stillwell. It is not much of a stretch to imagine that the amount of energy the plant needed to produce required more labor than could be procured with a humane workload during this period of ever-increasing demand for electrical power.

To establish a sense of just how much the citizens of Baltimore relied on the streetcars to move around the city one need only look at the figures from the 1907 walk-out. The lines were out for only an hour and a half, but during that time an estimated 100,000 Baltimoreans were compelled to walk who would otherwise have been riding the streetcars. ${ }^{45}$ That constituted about one fifth of the total population of the city, and only the central most lines were shut down. ${ }^{46}$ Furthermore, the reaction against the boiler room workers was quite vehement in the Baltimore press, which was quick to point out that walking home in such winter conditions (which included

\footnotetext{
44 “CARS TIED UP: 25 Men At Powerhouse Quit At 4:45 P. M. and Thousands Walk," The Baltimore Sun, February 12, 1907, 14, accessed February 7, 2014 via ProQuest Historical Newspapers.

45 “THE UNITED'S TIE-UP ON MONDAY," The Baltimore Sun, February 13, 1907, 4, accessed February 7, 2014 via ProQuest Historical Newspapers.

${ }^{46}$ Campbell Gibson, "Population of the 100 Largest Cities and Other Urban Places in the United States: 1790 to 1990" U.S. Bureau of the Census Population Division Working Paper No. 27 (June 1998), accessed via U.S. Census Bureau, url: <http://www.census.gov/population/www/documentation/twps0027/twps0027.html>
} 
cold temperatures and the presence of ice and snow) would probably result in "much sickness and possibly some loss of life." ${ }^{47}$ This claim was almost certainly exaggerated, but Baltimoreans were nonetheless severely disgruntled by the stoppage.

Where twenty or thirty years before streetcar transit would not have even been an option, by 1907 people had become quite accustomed to quick and easy public transit. The Baltimore Sun spoke out quite strongly against the 'strike' and called the breakdown of streetcar operations an "annoying and indefensible inconvenience." 48 Less than ten years previously the streetcar situation in Baltimore was an abysmal confusion of competing lines and differing schedules, but the consolidation in the form of the United Railway \& Electric Company and the construction of the centralized Pratt Street Power Plant transformed the transit scene in Baltimore and raised the expectations of passengers.

\section{$\underline{\text { Architects \& Aesthetics in Industrial Works }}$}

Unifying these two structures are the designs of local architect Ephraim Francis Baldwin. Baldwin had previously worked for Niernsee \& Nielson, the firm responsible for the design of Camden Station, and was employed by the Baltimore \& Ohio on numerous projects. He was the latest in a long line of successful and well-known architects working in Baltimore going back to Benjamin Henry Latrobe II, and his stylistic choices reflected the Classical design lineage he came from. ${ }^{49}$

\footnotetext{
47 “THE UNITED'S TIE-UP ON MONDAY,” The Baltimore Sun, February 13, 1907, 4.

48 lbid.

${ }^{49}$ Michael J. Lewis, "Introduction," in E. Francis Baldwin, Architect: The B\&O, Baltimore, and Beyond, Carlos P. Avery (Baltimore: Baltimore Architecture Foundation, 2003), xv-xvii.
} 
E.F. Baldwin wasn't born in Baltimore, but he lived there for most of his life. His father was a civil engineer, a fact that may have influenced Baldwin's propensity for working on buildings that were traditionally the purview of engineers. The impact of his father's profession on Baldwin's career choices is speculative, as Alonzo Baldwin passed away in 1843, when Baldwin was only six. This event had immediate and important ramifications for the direction Baldwin's life would take as his mother decided to move her two children back to her family home in Baltimore. He did not receive a formal education in architecture, but instead apprenticed himself to John Rudolph Niernsee and James Crawford Neilson. ${ }^{50}$ It was an excellent place to begin an architectural career, as “The firm of Niernsee \& Nielson was... one of Baltimore's most prestigious and influential architectural firms..." of the period. Niernsee was from Vienna, Austria and had worked under Benjamin H. Latrobe II for the Baltimore \& Ohio Railroad. He teamed up with Nielson, a Baltimore local trained in Belgium. Niernsee \& Nielson carried on the sophisticated classicism established in the city's early years by men like Latrobe, Godefroy, and Mills. $^{51}$

Baldwin was definitively a part of this traditional, classical school of thought. When the Baltimore \& Ohio needed a new "house" architect, they looked to Baldwin to create the right kind of image for the railroad. Baldwin started working for the B\&O c.1872 and was kept on as the company's primary architect for about ten years, though his relationship with the railroad continued well after that. ${ }^{52}$ The architect designed numerous structures for the Baltimore \& Ohio, including hotels, depots, stations, freight houses, and the company's headquarters in downtown

\footnotetext{
${ }^{50}$ Carlos P. Avery, E. Francis Baldwin, Architect: The B\&O, Baltimore, and Beyond (Baltimore: Baltimore Architecture Foundation, 2003), 3.

${ }^{51}$ Avery, E. Francis Baldwin, 4.

52 Ibid.
} 
Baltimore. ${ }^{53} \mathrm{He}$ also did work for Baltimore's burgeoning streetcar industry. ${ }^{54}$ The relationship between Baldwin and the railways was symbiotic, proving profitable to each in turn: "E. Francis Baldwin and Baltimore's railroads had their greatest years together - the railroads as they underwent a spectacular growth spurt and Baldwin as he put a face on it. ${ }^{~} 55$

Whether or not Baldwin was responsible for the face of either the Camden Warehouse or the Pratt Street Power Plant remains somewhat of a mystery. The destruction of both the B\&O's headquarters (a building designed by Baldwin) and his architectural office in the 1904 fire may offer some explanation for a decided lack of records pertaining to Baldwin's work for the railroad ${ }^{56}$ As such, no concrete proof exists that Baldwin was the designer of the Camden Warehouse. However, given his history with the company he and his partner Pennington are the most likely candidates ${ }^{57}$ Furthermore, the building fits in with Baldwin's aesthetic. Baldwin is not renowned for being the champion of any particular style of architecture, but Herbert $\mathrm{H}$. Harwood notes that he did have a tendency towards certain aspects of design: "If there was anything distinctively personal in his expression, it was a keen appreciation for the lithic solidity of the wall and the inherent poetry of masonry." 58 Such a description is certainly true to the design of the warehouse, the longest building on the Eastern Seaboard and well written verse of masonry poetics.

The evidence for Baldwin's involvement in at least part of the design of the Pratt Street Power Plant is more solid. At the start of the century, the newly formed United Railway \&

\footnotetext{
53 Ibid.,49.

${ }^{54}$ Ibid., 63-65.

${ }^{55}$ Lewis, "Introduction," xi.

${ }^{56}$ Avery, E. Francis Baldwin, 15.

${ }^{57}$ Ibid., 60.

58 Lewis, "Introduction," xvii.
} 
Electric company needed "high-capacity, modern facilities...particularly...a large central electricity-generation plant..." and Baldwin was selected for the job. ${ }^{59}$ His records show he did work on the boiler house, the central building of the three structures that make up the power plant. ${ }^{60}$ His design was an addition to an earlier building put up by an independent streetcar company prior to consolidation, as discussed above, and because the plant “...was located near the center of the city, [it] was made as attractive as possible; its four commanding capped smokestacks and external coal conveyor system made it one of Baltimore's most memorable industrial buildings." ${ }^{\prime 61}$ Although only responsible for a portion of the building as it stands today, Baldwin put his mark into the power plant in the form of stripped classicism and his emphasis on the mass of the masonry wall.

As noted earlier in the chapter, the idea of employing architects for industrial design was a comparatively recent phenomenon tied up in the idea that all company buildings were part of a larger public presentation. Often these structures are representative of the preferred styles of the age, but rarely are they considered distinguished examples of architecture. This judgment is not entirely fair, however, as the design of industrial buildings required special consideration about functionality and efficiency while also conveying the proper public image:

The aesthetic basis of American industrial building design was an ideal of beauty based on function, utility, and process held by engineers, not the formality or picturesqueness associated with recognized architectural styles. There was an accepted correct "feel" or tone for industrial architecture that expressed strength, stability, and function and eschewed the use of lavish or extensive decoration. ${ }^{62}$

\footnotetext{
59 lbid., xiii.

${ }^{60}$ Avery, E. Francis Baldwin, 64.

${ }^{61}$ Lewis, "Introduction," xiii.

62 Ibid., xiii.
} 
This is certainly not to say that the Camden Warehouse and the Pratt Street Power Plant do not partake, to a certain extent, of the design trends of the turn-of-the-century. Stripped down Classicism pervades the design of both structures, adding a sense of grandeur to their already daunting scale.

Ornamentation played its role, but the key here is that there was beauty in the functionality of the building regardless of decorative details. The immense capacity of the Camden Warehouse and the use of emerging technologies, such as fireproofing and hydraulic elevators, all contributed to its ability to fulfill its purpose. On Pratt Street, the case of the power plant is even more compelling. The area wiped out by the Great Fire of 1904 included all of the Pratt Street Piers, and yet, when the smoke cleared the power plant remained (Fig. 1.17). ${ }^{63}$ How it survived when so many other buildings did not is something of a mystery, but survive it did. ${ }^{64}$ One possible explanation is that the tremendous care taken in fireproofing the building (a necessary precaution for a structure where coal was burned and electricity generated) that ultimately ended up saving it from the flames. Notwithstanding its miraculous escape from the fire, when the power plant was built it was hailed by the New York Times as a wonder of modern technology, noted for its high capacity and its new equipment. ${ }^{65}$ Baltimoreans did not begin to praise the architecture of the building until many years later when it was remade for new uses. ${ }^{66}$

\footnotetext{
63 "Great Baltimore Fire of 1904," Maryland Digital Cultural Heritage Project, Enoch Pratt Free Library, last modified 2004, url: <http://www.mdch.org/fire/\#>

${ }^{64}$ Lewis, "Introduction," xiii.

65 "New Power Plant for Baltimore," The New York Times, November 3, 1904, 10.

66 "A Cathedral of Power from Yesteryear," The Baltimore Sun, February 18, 1979, SM2, accessed February 7, 2014 via ProQuest Historical Newspapers.
} 
Primary value in industrial buildings was judged on the basis of functionality, not style, but that did not mean the two were mutually exclusive. Companies had a stake in the external appearance of buildings as well as in their ability to function well:

...industrialists also had a real interest in the appearance of their works, which represented considerable financial investment and hopes for continued economic success. Works that appeared substantial and commodious also implied technological and organizational mastery. Interest in an attractive factory was coupled with pride in ownership and the desire for a prominent position in the community. A view of the factory works - only slightly idealized - often appeared in business letterhead and advertising. The high visibility of a plant in an urban area prompted attention to its appearance... ${ }^{67}$

Certainly the exterior details of both the Camden Warehouse and the Pratt Street Power Plant can be traced back to the importance of presenting industry to the public in as palatable a way as possible. ${ }^{68}$ Where smoke and grime were often the result of industrial efforts, industrialists used a restrained amount of aesthetic charm to lend elegance to these practical building, thus offering up industry in a neatly wrapped neoclassical package. What the businessmen who commissioned works of this nature could never have imagined was that in less than one hundred years the industries by which they made their fortunes would be rendered obsolete. When deindustrialization struck Baltimore, the empty shells of buildings that once stood as testaments to the strength and profitability of the railway would be all that remained of the industrial past.

${ }^{67}$ Bradley, The Works, 203

68 Ibid., 204. 


\section{Chapter Two: Survivors of the Post-Industrial Age}

\section{$\underline{\text { A Changing World }}$}

The wider world first opened up by companies such as the Baltimore \& Ohio and the United Railway \& Electric Company came with a price. New transportation technologies heralded a new era of modernity where people and their daily activities would no longer be bound to a restricted geographic area. Streetcars and railroads lifted the impediments imposed on mobility by the limitations of pedestrian and equine stamina, but they also created opportunities for people to leave the inner city. Following the end of World War II, many of Baltimore's citizens with the means would do just that, taking the bulk of spending power from the city to the suburbs.

The thirst for new technology and increased consumer convenience drove not only the end of rail power, but the serious downsizing of all American industry. The American consumer demanded goods that were cheap and readily available. They demanded the convenience and freedom of personal transportation. They demanded all the space and clean air of the country with all the culture and commodities of the city. Changes in the ways most Americans choose to live following the Second World War had serious implications for heavily industrialized cities like Baltimore. Industries were abandoned, labor was outsourced, those with discretionary income fled to the suburbs, and crime pervaded the inner city.

The promise of prosperity in the early decades of the twentieth century turned out to be empty for the city, as dramatic changes in technology and the rise of a global economy toward the end of the millennium brought about the end of the city's industrial heyday: 
In 1970, Baltimore employed 102,672 workers in manufacturing, out of a total 499,000 employed-20.5\%. In 2005, only 17,800 (projected) are in manufacturing out of 365,900 employed-4.8\%. This means that this former industrial powerhouse is more deindustrialized than any of the "Rust Belt" cities of the Upper Midwest, or the nation as a whole. Baltimore was downshifted into the "services" economy, and low-wage poverty. Today, $90 \%$ of all jobs in Baltimore city are service-providing jobs. ${ }^{69}$

The process that brought Baltimore low was called 'deindustrialization' and it began to plague many industry-centered American cities in the 1960s. Deindustrialization took the thriving American metropolis of Baltimore and transformed it, leaving the city in a state of urban decay by the end of the twentieth century. The cultural and technological changes that so deeply impacted the city's industries also changed the fate of Baltimore's railways.

\section{Streetcars: Here and Gone:}

Well before deindustrializing took its terrible toll on the cityscape, the streetcar lines were unwittingly laying the groundwork for the urban flight that would weaken the city in later years. The coming of the streetcar allowed people to live many miles from the city center, thus opening up suburban life as a viable option for Baltimoreans. The lines were designed to facilitate this kind of movement between the suburb and the city, as they "radiated in an outward fashion around the city's core." ${ }^{70}$ At first, suburban residents tended to be industrial workers from the shipyards or factories downtown. ${ }^{71}$ Suburbanites in this period still relied on the city not only for employment, but also for most of their other needs, including culture and entertainment. This type of "first-tier suburb" is radically different from the enormous sprawl that now oozes

\footnotetext{
${ }^{69}$ EIR Economics Staff, “The Case of Baltimore: Deindustrialization Creates 'Death Zones,' Executive Intelligence Review (2006): 9. url:

<https://www.google.com/search?q=eir+economics\&oq=EIR+econ\&aqs=chrome.1.69i57j013.2732j0j7\&sourceid=c hrome\&espv=210\&es_sm=122\&ie=UTF-8>

70 Thomas J. Vicino, Transforming Race and Class in Suburbia: Decline in Metropolitan Baltimore (New York:

Palgrave Macmillan, 2008), 38.

71 Ibid., 38-39.
} 
forth from most major American cities: "One of the most important features of urban development is that the transportation network linked the first-tier suburbs to the central city...These suburbs were socially and economically dependent on the City of Baltimore. Early on, the central city provided life for these suburban areas."72 Today, suburbs are often fairly selfsufficient, and many suburban residents can live comfortable without venturing into the city at all. Perhaps more significantly, it is often the case that the city now relies on the suburbs for economic support, in the form of disposable income coming into the city's retail and entertainment destinations. This is certainly the case in Baltimore, where many of the redevelopment downtown relies heavily upon tourist and suburbanite dollars to remain viable.

Late twentieth century suburbs however, were the product not so much of streetcars as of another new form of transportation: the automobile. Streetcar lines allowed people to live in the suburbs for the first time, but the automobile allowed escape from the city on each individual's personal schedule and soon eclipsed the streetcar as a preferred method of mobility. No more would power overloads or worker walkouts prevent evening commuters from making it home in time for dinner. Even in terms of public transit the domination of the automobile over the railways wasn't long in coming. The first buses were actually part of a subsidiary owned by the UR\&E, and were in operation by $1915 .^{73}$ As personal vehicles continued to improve and become more widely available, and buses became preferred modes of transit, the streetcar began to suffer, not just in Baltimore, but around the country.

In 1921, the financially troubled United Railway \& Electric Company opted to cease producing its own electricity. Instead, they signed a contract with the Baltimore Consolidated

\footnotetext{
72 Ibid., 41.

${ }^{73}$ Gary Helton, Baltimore's Streetcars and Buses, Images of America (Charleston: Arcadia Publishing, 2008), 33.
} 
Gas, Electric Light \& Power Company to have power supplied to their streetcars. As part of this agreement, the UR\&E sold the Pratt Street Power Plant to the gas and electric company for \$4 million, money they needed to pay off substantial debts. By the time this sale went through, the Pratt Street Power Plant was already secondary to streetcar operation, a scant twenty to fifteen years since its construction. Several years prior to the sale of the plant, the UR\&E had contracted with the Pennsylvania Water and Power Company for power from their hydroelectric plant, making the UR\&E's own power plants ancillary in importance. At the time of sale the plant was only used during peak hours and emergencies. ${ }^{74}$

Despite the capital made available to the United Railway \& Electric Company from the sale of the Pratt Street Power Plant, the company's financial challenged proved too great to overcome: “Already cash strapped, United was facing $\$ 8$ million in bond obligations due between 1929 and 1932. On January 6, 1933, the company declared bankruptcy. Reorganized, it emerged in 1935 with $\$ 50$ million in new capital and a new name, the Baltimore Transit Company."75 Unfortunately for the streetcar, the 1940s and 1950s were a period of enormous growth of roadway infrastructure in Baltimore that would prove fatal to the streetcar. ${ }^{76}$

Despite the creation of this new company and a short-lived resurgence of streetcar traffic during World War II, nothing could compete with the allure of the car and the powerful companies behind its production and use. Firestone, Standard Oil, and General Motors joined forces to fund the National City Line, a holding company created "for the express purpose of acquiring and dismantling urban streetcar operations." 77 There were a number of factors at play

\footnotetext{
74 "UNITED IN NEW DEAL FOR PERPETUAL POWER: Contract With Consolidated Involved Sale of Pratt Street Power House," The Baltimore Sun, January 13, 1921, 18, accessed February 7, 2014 via ProQuest Historical Newspapers. ${ }^{75}$ Helton, Baltimore's Streetcars and Buses, 51

${ }^{76}$ Vicino, Transforming Race and Class in Suburbia, 41.

77 Helton, Baltimore's Streetcars and Buses, 85.
} 
here. The financial power of companies with a vested interest in increased use of automobiles, the availability and cheapness of gasoline, and the desire among Baltimore's politicians to generate more tax revenue through the increased consumption of fossil fuels. Against such an onslaught, the streetcar stood little chance.

Additionally, the period following World War II saw the creation of new highway systems all over the United States. I-695, Baltimore's beltway, was constructed between 1953 and $1962 .^{78}$ The creation of the city's beltway was only the first on many new road projects for Baltimore:

Millions of dollars from Washington gave the region a beltway, encouraging sprawl beyond the city limits; a north-south commuter highway following the bed of the Jones Falls and ending near City Hall; a bridge over the Patapsco River easy of Fort McHenry and two tunnels under the harbor, one in the 1950s and another in 1970s. Federal money produced a partial subway system, which carries commuters to and from the northwestern suburbs to downtown and west to the Johns Hopkins medical campus. More money gave riders a light rail line... ${ }^{79}$

The automobile pushed suburbs well beyond the reach of the streetcar and alienated the suburban dwellers from the city center. In late 1963, sixty-four years after the consolidation of Baltimore's independent streetcar companies into the United Railway \& Electric Company, the last of Baltimore's streetcars stopped service.

\section{The Demise of the Railroad}

The Baltimore \& Ohio also suffered from the same shift in transportation technology that was ultimately responsible for the end of the streetcar. Passenger trains were a major component of the $\mathrm{B} \& \mathrm{O}$ for many years of its operation, but with the increasing use of automobiles and the

\footnotetext{
78 Vicino, Transforming Race and Class in Suburbia, 41.

${ }^{79}$ Hayward, Architecture of Baltimore, 277,
} 
eventual commercialization of air travel, passenger trains seemed almost archaic in comparison. ${ }^{80}$ The $\mathrm{B} \& \mathrm{O}$ was also subject to the whims of the American economy. It suffered mightily during the Great Depression and profited nicely during World War II, but the low and highs of the first half of the century moderated out into stagnation following the end of the war. ${ }^{81}$ During the 1950s, the railroad company began to dismantle infrastructure it wasn't using, including portions of Camden Yards:

Camden itself had also suffered some trimming down. During a 1951 renovation project...the old terminal received an exterior restoration and interior remodeling - but at the same time lost its two iron train sheds, the third floor of its one remaining end wing and the single surviving decorative cupola. Ten years later...its lower level platform was also dismantled. ${ }^{82}$

The warehouse was spared from any such changes, and continued to stand, essentially unaltered since 1905 (Fig. 2.1). The Baltimore \& Ohio, however, struggled on in an economy that increasingly seemed to have little use for the myriad railroad companies scattered across the American continent.

By the 1960s, the B\&O was in serious financial straits. ${ }^{83}$ Passenger service on the Old Main Line went out in 1949, tracks had been reduced on underutilized routes, and steam power locomotives were replaced with diesel, but still the company languished. ${ }^{84}$ Some of the industries they had relied upon for rail business began to disappear, new industries were located far from the rail lines of the old commercial districts, or companies opted to put their freight on trucks rather than on long haul trains. ${ }^{85}$ The situation created by these various factors made the B\&O

\footnotetext{
${ }^{80}$ Stephen J. Salamon, David P. Oroszi, and David P. Ori, Baltimore and Ohio: Reflections of the Capital Dome, New York to Cumberland (Silver Spring: Old Line Graphics, 1993), 5.

${ }^{81}$ Harwood, Impossible Challenge, 168-174.

${ }^{82}$ Harwood, Impossible Challenge, 177.

${ }^{83}$ Stephen J. Salamon, David P. Oroszi, and David P. Ori, Reflections of the Capitol Dome, 5.

${ }^{84}$ Harwood, Impossible Challenge, 174-177.

85 Ibid., 178.
} 
financially vulnerable and in 1963 the Baltimore \& Ohio was forced into affiliation with the Chesapeake \& Ohio Railroad. Less than ten years later, the combined B\&O and C\&O were also joined with the Western Maryland Railroad and became the Chessie System. Consolidation continued, and in 1980 another merger took place, resulting in the CSX Corporation. By 1987, the Baltimore \& Ohio Railroad Company ceased to exist as a corporation. ${ }^{86}$

Miraculously, the Camden Warehouse survived unscathed through these numerous upheavals in the Baltimore \& Ohio's history. Why it escaped destruction is not entirely clear, though it is likely that its downtown location and massive amounts of storage capacity played a role (Fig. 2.2). It continued to serve as a storage space for the railroad through the 1950s, but by the 1960s there was talk of finding new uses for the valuable land occupied by the Camden Yards site. ${ }^{87}$ A proposal in 1965 included a mixed-use commercial and residential area in the tradition of the much lauded Charles Center. ${ }^{88}$ Later on, and in a moment of accidental foreshadowing, developers looking to create a sports complex had their eye on the site. There was a certain amount of backlash again the idea of destroying Camden Yards, though most of the protestation was centered on Camden Station. ${ }^{89}$ As time went on and the revitalization sparked by Charles Center spread to other areas of downtown, Camden Yards become an increasingly

\footnotetext{
${ }^{86}$ Stephen J. Salamon, David P. Oroszi, and David P. Ori, Reflections of the Capitol Dome, 5.

${ }^{87}$ Peter Richmond, Ballpark: Camden Yards and the Building of an American Dream (New York: Simon \& Schuster, 1993), 134.

${ }^{88}$ Charles Center was a project of the Greater Baltimore Committee. The goal was to redevelop a swath of downtown Baltimore as a commercial district. The award-winning project featured over a dozen major buildings of modern design. Planning for the project started in 1957, and One Charles Center, designed by Ludwig Mies van der Rohe, was completed in 1962. Charles Center was added to through 1975. Source: Hayward, The Architecture of Baltimore, 278-285.

${ }^{89}$ Michael S. Franch, “Camden Station: Vivid Past, Cloudy Future," The Baltimore Sun, March 16, 1975, M12, accessed February 7, 2014 via ProQuest Historical Newspapers.
} 
desirable piece of commercial real estate. As the century progressed, early postwar redevelopment spread to the Inner Harbor and eventually west to Camden Yards.

\section{$\underline{\text { Redevelopment: Inner Harbor }}$}

Facing a deindustrializing economy and an increasingly service oriented market;

Baltimore began to work on reshaping the city's built environment to accommodate the changing economic landscape. The desire to see Baltimore restored to its former glory was driven not only by the concerned citizenry, but by shifts in global politics as well. As the tensions between the United States and the U.S.S.R escalated drastically following World War II, the battle for world dominance manifested itself in a variety of ways. One form this conflict took was as an ideological contest in the spheres of urban planning and architecture. ${ }^{90}$ In the early days of the Cold War, this was a battle Americans feared they were losing:

-communism, in the minds of many influential Americans, appeared to be outpacing the United States in creating an appealing (if to their minds entirely illusory) version of the good life. In the race to convert countries around the globe, the United States had to demonstrate, particularly within its own borders, that its economic and political system could deliver the good life to urban majorities. ${ }^{91}$

And losing was precisely what the cities were doing. In the case of Baltimore, 162,933 residents

left the city between 1950 and $1980 .{ }^{92}$ This exodus was brought on in part by a number of city

problems, which were driven primarily by the loss of traditional work as a direct result of

deindustrialization. Baltimore, like many American cities, was forced to embrace a new

\footnotetext{
90 Nicholas Dagen Bloom, Merchant of Illusion: James Rouse, America's Salesman of the Businessman's Utopia. Urban Life and Urban Landscape Series (Columbus: Ohio State University Press, 2004), 1.

${ }^{91}$ Bloom, Merchant of Illusion, xii.

92 Richard L. Forstall, "MARYLAND - Population of Counties by Decennial Census: 1900 to 1990," accessed April 21, 2013,url: <http://www.census.gov/population/cencounts/md190090.txt>
} 
economic culture, one driven by the service industry rather than the manufacturing industry. ${ }^{93}$ This shift in the Baltimore economy created an opportunity for renewing the city's industrial harbor area as a new center of commerce and reimaging abandoned industrial buildings like the Pratt Street Power Plant and the Camden Warehouse as spaces of opportunity for new commercial endeavors.

As concerns about the fate of the downtown grew, a group of civic leaders formed the Greater Baltimore Committee and began to set the renewal of downtown Baltimore in motion. They focused their efforts and their money on the creation of Charles Center, a new commercial center for the city. The project also marked a new era in Baltimore's architectural history, as the new office buildings that rose up ushered Baltimore into the modern age, and included the works of well-known architects like Mies van der Rohe and John M. Johansen. ${ }^{94}$ Charles Center paved the way for the city to take another look at the dilapidated harbor. At first, the harbor continued to cater to businessman, with the construction of the Baltimore World Trade Center and the Baltimore Convention Center. ${ }^{95}$ Developer James Rouse, however, wanted to "create an attraction uniquely suited to the diverse character of Baltimore..." in keeping with the tradition of long-standing market spaces such as the Lexington Market just a few blocks from the Inner Harbor. $^{96}$

Rouse was a native of Maryland and was drawn to Baltimore by the opportunity to recreate the success of his adaptive reuse of Faneuil Hall in Boston. Rouse turned the historic Boston lecture hall into a "festival marketplace," a modern take on the traditional community

\footnotetext{
93 Hayward, Architecture of Baltimore, 277.

94 Ibid., 280-285.

95 Ibid., 288-290.

${ }^{96}$ Bloom, Merchant of Illusion, 167.
} 
market. ${ }^{97}$ That effort became a commercial success and gave American cities a new vision of urban renewal that embraced the culture and character of place, at least on a superficial level. The two pavilions designed for Rouse's Harborplace didn't utilize existing buildings, but they were inspired by traditional forms of waterfront architecture, including boathouses, warehouses, ferry terminals and pleasure pavilions (Fig. 2.3) ${ }^{98}$ The construction of Harborplace laid the foundation for the continued renewal of the Inner Harbor and restored a sense of pride to a hurting city. As the Washington Post reported on opening day:

Harborplace officially opened today amidst much fanfare and flocks of Baltimoreans. And for [Natalie Paymer] that meant that she wasn't ashamed to live in Baltimore anymore. "Baltimore has become a place, and now it's a place people wouldn't ignore," Paymer said. "I was embarrassed to say I was from Baltimore. It was so zero here. There was nothing to do."

Harborplace became an anchor for the Inner Harbor, and encouraged developers to consider similar projects in nearby locations, such as the derelict rail yard sitting in the shadow of the mammoth warehouse a few blocks away.

\section{$\underline{\text { Retro Ballpark }}$}

The renewal of the Inner Harbor was not limited to new construction. ${ }^{99}$. At the end of the decade, another developer from Washington, D.C., Oliver T. Carr, announced a scheme to turn Camden Yards into housing, offices, and a hotel. During this period, Camden Yards was not in particularly good shape. One Baltimore Sun reporter described it as “...a bleak expanse of largely unused railroad tracks and warehouses..." and the buildings on the property were no

\footnotetext{
${ }^{97}$ Ibid. 150-154

${ }^{98} \mathrm{lbid}$.

${ }^{99}$ Franch, "Vivid Past, Cloudy Future," The Baltimore Sun, March 16, 1975, M12.
} 
longer serving any useful function (Fig. 2.4). ${ }^{100}$ The warehouse continued to be in use until 1974, when its doors were finally closed and Camden Station was only servicing a small number of commuter trains in this period. ${ }^{101} \mathrm{Mr}$. Carr proposed a ten year plan with a total investment of $\$ 170$ million private funds going into the venture.

The first phase of the Carr development would have cost an estimated \$20 million to turn the Camden Warehouse into condominiums and transform Camden Street into a pedestrian mall by 1981 . By 1983, construction still had not begun on any part of the project and the initial design for the 22-acre complex had undergone several changes. One of these directly affected the Camden Warehouse, when developers scrapped plans for turning it into condos and instead sold the warehouse off to developer Morton Macks. The Macks group planned on turning the Camden Warehouse into a commercial complex called "Harbor Exchange." The new commercial venue would be filled with outlet shopping and was intended to cater to an upper middle-class clientele (Fig. 2.5). Initial designs for the project included a “...three-story glass addition to be built on the warehouse's east front, the long side that faces the Inner Harbor."102 The integrity of the building's exterior, however, was not destined to be encased in a glass cage, as Macks eventually abandoned his plans and sold the warehouse to the city for $\$ 11$ million, a sale which opened the door for the creation of a new stadium, and a new icon for the city of Baltimore. ${ }^{103}$

For years there had been talk of putting a stadium on the site of Camden Yards, but in the waning years of the 1980s all the talk finally turned into something real: The Baltimore Orioles,

\footnotetext{
${ }^{100}$ C. Fraser Smith, "Plan would make bleak Camden yards a \$170 million living-working complex," The Baltimore Sun, May 23, 1979, A1, accessed February 7, 2014 via ProQuest Historical Newspapers.

101 Thom Loverro, Home of the Game: The Story of Camden Yards (Dallas, Texas: Taylor Publishing, 1999$), 41$.

102 Sandy Banisky, "Camden complex planned: Zoning requested for stores, offices in old warehouse," The Baltimore Sun, September 29, 1983, E1, accessed February 7, 2014 via ProQuest Historical Newspapers.

103 Richmond, Ballpark, 135.
} 
the city's major league baseball team, were getting a new stadium. That much was certain. The fate of the warehouse, however, remained a question mark as the design process got underway. HOK became the firm charged with designing the new ballpark, but the design challenge of Camden Yards proved to be unlike their previous work in the field of sports complexes. Stadium building in late twentieth century America was dominated by concerns for maximum seating and parking over any aesthetic considerations. As Peter Richmond points out, there are several aspects of stadium design that make it appealing as an architectural undertaking:

[Stadiums are] extremely lucrative - a quarter of a billion dollars' worth of contracts went out on Camden Yards. They don't take much design talent; they're virtually unchanged from ancient Greek times, save the addition of luxury boxes and club seats. And - most significantly...they're about as inconspicuous as a tarantula on a slice of angel food...which means that your work is extremely visible, all of the time. ${ }^{104}$

Essentially, stadiums required comparatively little work yet came with a huge payoff in the form of notoriety. As a consequence, the stadiums of the second half of the twentieth century tended to try to make up for a lack of character with their overwhelming size.

There was a sense among those close to the project that the stadium in Baltimore, unlike so many precast concrete megaliths of the time period, should actually respond to the environment and history of the city around it. Camden Yards was supposed to bring something back to baseball, and to Baltimore: "If they wanted an old-style park...it was necessary for the new stadium to be familiar with the brick-skinned textures of America's machine age. Most of the old parks were true to the industrial rub of their cities." 105 Part of creating that "industrial rub" in a new stadium involved the inclusion of the Camden Warehouse.

\footnotetext{
104 Richmond, Ballpark, 103.

105 Ibid., 130.
} 
Precisely who thought of the idea of incorporating the warehouse into the new ballpark remains a point of contention. Architectural student Eric Moss created a model for the stadium that included the whole warehouse, where the firm of HOK suggested keeping only half of the venerable old building. Initially, the Orioles had no real interest in preserving the warehouse anyway, but ultimately saving the warehouse and turning it into office space for the team was a cost saving measure that the financially strapped Maryland Stadium Authority could not afford to pass up. ${ }^{106}$

Although HOK's design called for keeping a portion of the warehouse, the building remained on shaky ground throughout 1988. Feeling in the wider Baltimore community had gone from apathy to active support for keeping the old industrial structure, as the Baltimore Sun reported:

The architect's report issued yesterday noted that the idea of saving the eight-story warehouse also has the support of the city government, the architectural community, historic preservationists and the surrounding neighborhood organizations. "We've seen a lot of sentiment from the community and from the city of Baltimore for the building to stay," said Richard deFlon, vice president of HOK Sport Inc., the lead firm in the stadium design team. "It's a historic structure...It's a sound building. It's a landmark on the site."107

In the final version of the plans, the warehouse was spared from destruction and integrated into the stadium, with its interior providing copious office and storage space and the exterior serving as the brick backdrop to right field of the nation's first retro ballpark (Fig. 2.6). ${ }^{108}$

Fits and Starts: Commercial Enterprises in the Power Plant

\footnotetext{
106 Loverro, Home of the Game, 29-31.

107 Edward Gunts, "Old warehouse may be made part of stadium site," The Baltimore Sun, December 28, 1988, 1D, accessed February 7, 2014 via ProQuest Historical Newspapers.

108 Loverro, Home of the Game, 28.
} 
The Pratt Street Power Plant was decommissioned in 1973, opening it up to redevelopment. There is no indication that the building was ever in any serious danger of being demolished, and proposals for new uses started flowing in just a few years after it ceased operations as a power plant. ${ }^{109}$ The first move towards adaptive reuse came in 1976, when the power plant was under consideration as a future site for a new maritime museum. After sitting idly for three years, the Baltimore Sun described the building as “... a gloomy pile on Pratt Street with four distinctive smokestacks and a handsome Romanesque section on the harbor side," a description that reveals both the depressed nature of the deindustrialized harbor and the already developing interest in the romance of industrial ruins. ${ }^{110}$ Ultimately the site was not selected, and the power plant went through a series of failed attempts to secure a new tenant. A \$55 million luxury hotel was on the table in 1979 , but not enough funding could be secured and the idea was shelved. ${ }^{111}$

By 1983, a proposal very different from a maritime museum or hotel was underway for the power plant. The Six Flags Corporation proposed to turn the old industrial building into a new kind of amusement park, a project that Baltimoreans greeted with both excitement and anxiety (Fig. 2.7). In the project's favor was the general feeling that Six Flags had the capital and name recognition to succeed in making the power plant a viable tourist attraction downtown:

The proposal of the Six Flags Corporation to develop the old powerhouse on Pier 4 into an urban theme parklet is imaginative and promising. It would re-use a monumental structure from Baltimore's past that deserves to survive in present form but that had defied previous re-cyclers. It would bring more people to the Inner Harbor, provide employment and promote spending. It would, after all these years of city subsidies, bring in commercial

\footnotetext{
${ }^{109}$ Dennis M. Zembala, ed., Baltimore: Industrial Gateway on the Chesapeake Bay (Baltimore: The Baltimore Museum of Industry, 1995), 36.

110 "Harbor sites weighed: Historical unit studies new maritime museum," The Baltimore Sun, November 21, 1976, A18, accessed February 7, 2014 via ProQuest Historical Newspapers.

${ }^{111}$ Stephen J. Lynton, "New Magic in Store of Old Power Plant," The Washington Post, January 17, 1983, WB1, accessed July 7, 2013 via ProQuest Historical Newspapers.
} 
investment at outsiders' risk. The amusement place would reinforce the development of the onetime commercial waterfront as a resort, complementing the marina, restaurants and gewgaw of shopping stands. ${ }^{112}$

At the same time, however, residents expressed trepidation about turning a piece of Baltimore history into a theme park. The proposal specifically called for attractions that would be themed around turn-of-the-century America, complete with “...crystal skylights, lush interior landscape, red-carpeted stairways, polished brass Victorian rooftops and tintype toys..." and some felt that the faux-historic amusement park seemed trite placed within the vicinity of authentic Baltimore neighborhoods little changed since the Victorian era (Fig. 2.8). ${ }^{113}$ In the end, the promise of a successful commercial enterprise on the waterfront trumped these concerns.

Six Flags spared no expense in their remaking of the Pratt Street Power Plant. The company initially spent almost \$20 million dollars and employed the likes of famous science fiction writer Ray Bradbury to create the ultimate fantasy experience. It was estimated that 200 to 300 jobs would be created by the venture. ${ }^{114}$ Furthermore, the City of Baltimore expected to earn a minimum of $\$ 1.5$ million annually as a result of the development. Some attention was paid to the true history of Baltimore, in the form of a basement museum. While the majority of the attraction centered on the entertainment value of the sanitized and dramatized past upstairs, the museum offered a small glimpse into the city's industrial past with a "heritage hall." However, the hall was a comparatively minor portion of the overall project. ${ }^{115}$ Former Baltimore area resident Bryan Harness recollects that the Heritage Hall consisted of a few panels about the

\footnotetext{
112 "Six Flags in a One-Flag Town," The Baltimore Sun, January 1, 1983, A14, accessed February 7, 2014 via ProQuest Historical Newspapers.

113 Matt Seiden, “Does Baltimore want Six Flags' plasticized version of history?” The Baltimore Sun, January 7, 1983, C1, accessed February 7, 2014 via ProQuest Historical Newspapers.

114 Lynton, "New Magic in Store for Old Power Plant," The Washington Post, January 17, 1983, WB1.

115 Sandy Banisky, "Six Flags likely to earn city \$1.5 million a year," The Baltimore Sun, June 30, 1983, D4, accessed February 7, 2014 via ProQuest Historical Newspapers.
} 
general history of Baltimore and the power plant, but the display was not on par with the kind of exhibits found in a more traditional museum. ${ }^{116}$

Completed in 1985, the new entertainment center housed a glittering array of entertainments for visitors to sample (Fig. 2.9). The experience centered around four shows, the Magic Lantern Theater, the Circus of the Mysterious, the Laboratory of Scientific Wonders, and The Sensorium. The shows relied on animatronics, laser holographs, and 3D film combined with other sensory elements focused on smell and touch. Additionally the complex offered the museum, restaurants, and an arcade area. ${ }^{117}$ Despite the expense and effort poured into turning the power plant into The Power Plant, the venture struggled from the start.

Not even a year after it opened the Power Plant was having difficulty remaining financially viable, and a new general manager had to be hired. Six Flags brought in the marketing director of the 1984 Olympics and continued to throw money at the project. What was originally not even a $\$ 20$ million price tag for the venture had ballooned into $\$ 33$ million in costs by the spring of $1986 .{ }^{118}$ Under severe economic pressure, the carefully planned turn-of-thecentury family entertainment facility lasted only 18 months. In January of 1987, Six Flags announced the Power Plant would be turned into a nightclub with P.T. Flagg's (the only successful portion the original complex) as the centerpiece. Aimed at an adult audience, the plans called for a focus on food, drinks, and live music. ${ }^{119}$ Although the nightclub itself was successful, it accounted for a small portion of the building and could not fill the underutilized

\footnotetext{
${ }^{116}$ C. Bryan Harness, interview by Virginia Harness, Lynchburg, Virginia, April 25, 2014.

${ }^{117}$ Hank Buchard, "Watt's New? The Power Plant," The Washington Post, July 26, 1985, 43, accessed July 7, 2013 via ProQuest Historical Newspapers.

118 "Six Flags Corp. Vows to Succeed at Power Plant," The Washington Post, March 24, 1986, WB11, accessed July 7, 2013 via ProQuest Historical Newspapers.

${ }^{119}$ Ellen Uzelac, "Six Flags closing Power Plant, going disco: New night spot wil feature live music, food," The Baltimore Sun, January 7, 1987, 1E, accessed February 7, 2014 via ProQuest Historical Newspapers.
} 
space or generate the kind of financial support necessary to keep the entire edifice up and running. By August, Six Flags was looking into selling their lease on the Pratt Street Power Plant. ${ }^{120}$ The concept of the urban theme park was dead, and the power plant was once again left vacant on the waterfront.

${ }^{120}$ Edward Gunts, "Six Flags to sell its lease on Power Plant," The Baltimore Sun, August 29, 1987, 1A, accessed February 7, 2014 via ProQuest Historical Newspapers. 


\section{Chapter Three: Selling Nostalgia}

\section{Waterfront Redevelopment Takes Off}

As Baltimore prepared to enter the final decade of the twentieth century, the futures of the Camden Warehouse and the Pratt Street Power Plant were tentatively secured. Frequently Baltimore is cited as the premiere example of urban waterfront redevelopment in the United States. The work done to bring the city back to life "rekindled its spirit and created a distinctive international image for itself through a systematic, entrepreneurial and beautiful makeover of its old Inner Harbor..." that began to have a serious impact on the downtown area. Where previously Baltimore's waterfront was dominated by industrial works, it was now a hub for the city's emerging tourist industry. Redevelopment created 15,000 jobs and increased harbor area property values by as much as $600 \%$. This kind of dramatic transformation earned the Inner Harbor redevelopment forty awards by the start of the new millennium. ${ }^{121}$

The Pratt Street Power Plant and the Camden Warehouse proved to be central components of the remaking of the waterfront. Although both buildings went through periods where their futures were uncertain, by the 1990s hope for their continued existence was renewed. As discussed in Chapter Two, the warehouse came very close to destruction in the early stages of planning for the new baseball stadium. However, with the idea to incorporate the aging brick giant into the ballpark, the warehouse received a reprieve from demolition. The power plant likewise experienced difficulties as several ventures moved in to the space only to fail and leave the plant abandoned once more. The time had arrived though when both the Camden Warehouse

${ }^{121}$ Marshall, Waterfronts in Post-Industrial Cities, 74-75. 
and the Pratt Street Power Plant would once again find their place within the renewed spaces of the Inner Harbor.

However, consideration must be given to the implications of the adaptive reuse of industrial buildings and of the decision to focus so many resources on such a small section of Baltimore. Though made financially viable through new commercial endeavors and integrated successfully into the service economy, this kind of reuse often had unintended consequences. Looming over the re-imagining of spaces like the power plant and the warehouse is the longing for Baltimore's past, a past which the future may never live up to. This nostalgia for the lost city runs as an undercurrent through many reuse developments in Baltimore, and corporations have learned to how to capitalize on this desire for what once was. The result is a vision of the old world which reveals little to nothing of the actual history of these places and turns preservation into commodification. Furthermore, the conversion of industrial buildings into service enterprises is part of a larger problem in the city, where the evolution of industrial jobs into service jobs often translates to lower wages and fewer opportunities.

\section{$\underline{\text { Success at Camden Yards }}$}

As described in the preceding chapter, the Camden Yards site went through a series of failed development plans until it was eventually designated as the future home of the Baltimore Orioles. The place of the warehouse in this new scheme remained shaky until 1988, when it was officially determined that the building would remain and be incorporated in the stadium itself. 1992 saw the grand opening of Oriole Park at Camden Yards, complete with a right-field 
backdrop unlike that of any other baseball park in the country in the form of the old warehouse constructed by the Baltimore \& Ohio Railroad almost a century earlier (Fig. 2.10). ${ }^{122}$

The process for determining whether or not to keep the warehouse was long and complex, but the final result was stunning, a triumph both aesthetically and financially. ${ }^{123}$ The words used to describe Oriole Park at Camden Yards in its early years take on an almost religious quality. In his book Ballpark, Peter Richmond describes the effect of the stadium on opening day with the reverence of someone relating a transcendent experience. In his ruminations he includes a brief nod to "...the warehouse, long and thick and chthonic, the oldest wall of any major-league stadium dominating the newest playing field..." before continuing to express the "overwhelming rightness" of the design of the stadium. ${ }^{124}$

Richmond's rhetoric may be heavy handed, but it was in keeping with the incredible sense of pride and success that accompanied the opening of the new ballpark. A few months after the spring opening, The Washington Post was reporting that attendance at Oriole's games had risen by $50 \%$ and many had been sellouts. The popularity of the new stadium suddenly put Baltimore on par with much larger cities with better funded baseball teams: “At the rate they're going this season, the Baltimore Orioles will draw as many fans as the New York Yankees and New York Mets - combined." For a city looking to breathe fresh life into its downtown area, what could be better than the consistent attendance of over 40,000 fans at the nearby baseball stadium? ${ }^{125}$ Additionally, credit for the unique character of the ballpark was immediately granted to the Camden Warehouse itself. When the crowds poured in on opening day, they took

\footnotetext{
122 Richmond, Ballpark, 16.

${ }^{123}$ Mark Potts, "Camden Yards: Baltimore's New Diamond Is a Gold Mine," The Washington Post, July 5, 1992, D1 accessed March 1, 2014 via ProQuest Historical Newspapers.

124 Richmond, Ballpark, 257.

125 Potts, “Camden Yards: Baltimore's New Diamond Is a Gold Mine," The Washington Post, July 5, 1992, D1.
} 
notice of the old industrial giant, "To most, the huge brick B\&O warehouse provided the park's signature touch, looming large behind the sign-festooned right field fence..." proving that the decision to keep the building and incorporate it into the stadium had been a sound one. ${ }^{126}$

Furthermore, the design of the rest of the ballpark didn't differ too dramatically from the original architectural language established by the Camden Warehouse (and, in a reversal of original importance, Camden Station). Red brickwork and arches dominate the other facades, while traditional slated seats added another touch of history to the park (Fig. 2.11). The attention to detail went still further, with the incorporation of signage that used the logo of the 1890s Baltimore Baseball Club and putting up an old-fashioned score board, complete with antique weather vane. ${ }^{127}$ The ultimate effect of Camden Yards drew regular crowds of 48,000 people, the full capacity of the park. The financial success of the stadium in the 1990s sparked other major league teams to follow the formula of Oriole Park and build ballparks that felt oldfashioned but provided every convenience of modernity. ${ }^{128}$

\section{From Boiler House to Bookstore}

A few blocks east on Pier 4, the Pratt Street Power Plant sat awaiting a new tenant following the disastrous redevelopment attempt made by Six Flags in the late 1980s. A proposal was made for a $\$ 30$ million 3D simulation sports complex in the early 1990s, but nothing ever came of the plan. ${ }^{129}$ In 1996 the Cordish Company, based in Baltimore, planned to finally

\footnotetext{
${ }^{126}$ William Gildea, "It's a Grand Opening for Camden Yards," The Washington Post, April 7, 1992, A1, accessed March 1, 2014 via ProQuest Historical Newspapers.

127 Hayward, Architecture of Baltimore, 320-321.

128 Loverro, Home of the Game, xiii-xv.

129 "Motion Simulator Slates for Md. Power Plant," The Washington Post, August 17, 1992, 21, accessed March 2 , 2014 via ProQuest Historical Newspapers.
} 
undertake the project. ${ }^{130}$ Baltimore leased the property to the Cordish Company for a period of 99-years and Cordish planned to invest an estimated \$20 million into the conversion of the power plant from a failed theme park into an entertainment and office space. ${ }^{131}$ Learning from the lessons of the failure of the Six Flags attempt, Cordish undertook a thorough analysis of the previous redevelopment and the sources behind its failure. The company had the city extend the pier to increase foot traffic and changes were made to the façade of the building to try and make it more enticing to visitors. ${ }^{132}$

The Cordish Company hired Design Collective, a design firm based in Baltimore, to make the building usable for new tenants. In a dramatic alteration to the western front of the boiler room, Cordish put in three enormous windows, spanning four floors. These allowed people to see into the building and make the structure seem more inviting (see Fig. i.3). Cordish also replaced the opaque window glazing with new glass, but replicated the old window frames to "maintain the historical look of the buildings." ${ }^{133}$ The architects working on the project “...treated the building as a three-dimensional jigsaw puzzle, creating retail spaces on the lower floors and offices above."134 The changes necessary to make the kind of space desired by the developers and future tenants were not insubstantial and radically altered the building's internal structure. $^{135}$

\footnotetext{
${ }^{130}$ Hayward, Architecture of Baltimore, 307

${ }^{131}$ Robert Sharoff, "Redevelopment Enriching Baltimore's Inner Harbor: Power Plant to get glass wall to show interior smokestacks," The New York Times, August 3, 1997, R5, accessed March 2, 2014 via ProQuest Historical Newspapers.

132 Hugh Cook, "Powered by retail," Building Design \& Construction 40, no. 8 (1999): 2. Accessed October 29, 2012.

${ }^{133}$ Hayward, Architecture of Baltimore, 307.

134 Ibid., 307-308.

135 Cook, "Powered by Retail," 3.
} 
The original X-bracing of the boiler house was switched out in favor of modern 'moment' frames, a structural change designed to accommodate the space requirements of the new tenant. Cordish leased the central section of the power plant to Barnes \& Noble, and the bookstore tenant required not only the changing of the structural supports but also accommodation for a 3,000 gallon aquarium (Fig. 2.12). ${ }^{136}$ Despite these changes, the effect of walking into this particular Barnes \& Noble is significantly different than the experience of entering other branches of the chain store. The interior is broken up by different floors and filled with merchandise, but nevertheless the cavernous feeling of the towering structure remains intact, aided by the presence of the great smokestacks left behind from the plants industrial days (Fig. 2.13). The copper-colored behemoths rise up through the floors, matched with painted green metal beams, complete with rivets, framing the store's escalators (Fig. 2.14).

The other original tenants of the power plant were the Hard Rock Café and the first ESPN Zone. The Walt Disney Company decided to debut its new sports themed restaurant and entertainment venue in Baltimore in 1997 due partly to the success of Camden Yards and the subsequent attention on the Orioles, and their football counterparts, the Ravens. ${ }^{137}$ All three tenants remained in place until 2010, when the ESPN Zone suddenly closed. ${ }^{138}$ It was swiftly replaced, however, by Phillips Seafood. Phillips was an anchor for the 1980 Harborplace development for many years, and by 2011, it was the last original tenant of that complex. In the fall of 2011 Phillips left the Light Street Pavilion for the Pratt Street Power Plant. The move was

\footnotetext{
136 Ibid.

137 Judith Evans, “Disney Does a Deal at Baltimore's Inner Harbor,” The Washington Post, October 15, 1997, C15, accessed March 2, 2014 via ProQuest Historical Newspapers.

138 Jamie Smith Hopkins, "ESPN Zone workers, employer reach settlement," The Baltimore Sun, November 3, 2013, accessed March 2, 2014, url: <http://www.baltimoresun.com/business/bs-bz-espn-zone-settlement20131101,0,2820437.story>
} 
partially a reflection on the condition of Harborplace itself, which has largely been transformed into a place to grab a quick meal or peruse a souvenir shop. With Harborplace moving in a more retail oriented direction, it made sense of Phillips to make the switch to the power plant where it is one of only three tenants. ${ }^{139}$

\section{$\underline{\text { Ruins Reused }}$}

Behind all the accolades for Camden Yards and the glittering lights of the Pratt Street Power Plant lurked a major new force of the collective American psyche: nostalgia. Though the word nostalgia has its etymological roots in Ancient Greek, the word didn't actually come into use until 1688. Originally, nostalgia was thought of as a medical condition, essentially homesickness treated as a disease. Though it perhaps seems comical from a modern perspective to think of nostalgia in medical terms, for many years it was assumed to be a very serious, and contagious, illness. In fact, the Russian army was so concerned over the spread of Nostalgia that in the 1730 s they threatened to bury alive any soldier displaying the symptoms of homesickness. With the coming of the Enlightenment, however, nostalgia moved out of the field of medicine and became the purview of philosophy. ${ }^{140}$

In the nineteenth century, nostalgia surfaced as a reaction to the many changes brought about by a series of societal shifts. In a period characterized by revolutions, both political and industrial, nostalgia emerged as a balm to soothe the trauma created by the many transformations taking place in people's lives. Deindustrialization created a similar effect and generated renewed

\footnotetext{
139 Chris Kaltenbach and Jill Rosen, "Phillips Seafood, the last of the original Harborplace tenants, to close," The Baltimore Sun, June 10, 2011, accessed March 2, 2014, url:

<http://www.baltimoresun.com/entertainment/dining/baltimore-diner-blog/bal-phillips-to-close-harborplacelocation-20110610,0,4719307.story>

140 Boym, The Future of Nostalgia, 1-12.
} 
interest in industrial buildings. Steven High and David W. Lewis note how these deindustrialized landscapes have resurfaced as a key part of urban tourism, "Industrial heritage tourism has expanded rapidly - an indication of its perceived value as a tool of economic development in hard-hit areas, and of a popular desire to learn about a "vanishing" way of life."141 This modern obsession with the industrial past is a form of intellectual epidemic. Cities across North America and Europe that once relied on industrial economies, including places like Baltimore, are gripped by a longing to a return of the glory days of the first half of the twentieth century, when industrial cities were central parts of Western civilization. Where a city in the throes of progress is often only too willing to dispose of the monuments of the previous age, the post-industrial urban environment, littered with the relics of its past success, is keen to preserve the best and brightest of what once was.

This desire is linked not only with the past, but with the future, and the lingering sense of what might have been:

[Industrial] ruins and their representation in picture books, films, and exhibits are a sign of the nostalgia for the monuments of an industrial architecture of a past age that was tied to a public culture of industrial labor and its political organization. We are nostalgic for the ruins of modernity because they still seem to hold a promise that has vanished from our own age: the promise of an alternative future. ${ }^{142}$

This "alternative future" is especially painful in the industrial cities that have largely failed to successfully make the transition from heavy industry to service. Baltimore poured its resources into creating a service sector in the commercial area at the city's center, but much of the rest of the city remains economically depressed and plagued by drugs, crime and disease. The labor jobs

\footnotetext{
${ }^{141}$ Steven High and David W. Lewis, Corporate Wasteland: The Landscape and Memory of Deindustrialization (Ithaca and London: Cornell University Press, 2007), 41-42.

142 Andreas Huyssen. "Nostalgia for Ruins." Grey Room 23 (2006):8.
} 
that once offered ample opportunity for the citizens of Baltimore to make a decent wage are gone, and the service jobs that replaced them are hardly equivalent in terms of pay and benefits. $^{143}$

Despite, or perhaps because of, the harsh realities of the rise of service over industry, the hunger for the reuse of industrial buildings remains strong. In a city plagued with socioeconomic challenges of the worst kind, an obsession with the past is only too understandable. The relentless march of time and progress, once the driving forces behind Baltimore's success, are now elements it battles against. As large swaths of the city succumb to urban decay, it becomes ever more important to preserve the sections that have eluded collapse. Reimagining industrial buildings is a way of keeping deterioration at bay, and the preservation of industrial behemoths like the power plant and the warehouse are part of the "...fear or denial of...ruination by time," creating spaces where time can be suspended while still making the benefits of progress available to those who can afford them. ${ }^{144}$

This particular form of nostalgia is defined by Boym as "restorative nostalgia," which combats the idea of the ruin through "... anti-modern myth-making of history by means of a return to national symbols and myths... Restorative nostalgia manifests itself in total reconstruction of monuments of the past..." ${ }^{145}$ While adaptive reuse cannot be classified as a "total reconstruction" the case for both the Pratt Street Power Plant and the Camden Warehouse as "monuments of the past" is not difficult to make. Although it was a falsification of the building's true history, the reuse of the power plant as a Six Flags attraction attempted to recreate

\footnotetext{
${ }^{143}$ EIR Economics Staff, “The Case of Baltimore: Deindustrialization Creates 'Death Zones,'” 4.

144 Huyssen. "Nostalgia for Ruins." 8.

145 Boym, Future of Nostalgia, 41.
} 
a bygone era with its focus on turn of the century showmanship. Similarly, the asymmetrical design of Oriole Park and Camden Yards was intended to remind baseball fans of the historic, early twentieth century stadiums at Ebbets Field and Fenway Park. ${ }^{146}$

As these reuse projects suggest, the importance of these two structures in the minds of Baltimoreans has less to do with how the buildings were viewed when constructed and everything to do with what the modern citizen perceives as the value of these structures. Where passerby in the early 1900s saw modernity and progress, the symbolism of the power plant and the warehouse has fundamentally changed as industrial buildings became relics of a bygone era. The continued monumentality of these buildings is of modern making, for as Alois Riegl notes, "It is not their original purpose and significance that turns these works into monuments, but rather our modern perception of them." ${ }^{147}$ Ironically, Riegl wrote those words around the same time the Camden Warehouse and the Pratt Street Power Plant were completed, and probably never foresaw that the infrastructure of industry would one day merit classification as "art."

In "The Modern Cult of Monuments," Riegl predicts that people in the twentieth century would value art and architecture primarily for their age-value. For Riegl, monuments with agevalue were essentially ruinous in appearance, thus betraying their age, and were to be appreciated as such, left to the ravages of time. When he composed his essay, such ruins were the height of artistic appreciation: "Every artifact thereby perceived as a natural entity whose development should not be disturbed, but should be allowed to live itself out with no more interference than

146146 Daniel Rosenweig, Retro Ball Parks: Instant History, Baseball, and the New American City (Knoxville: The University of Tennessee Press, 2005), 3.

${ }^{147}$ Alo is Riegl, "The Modern Cult of Monuments: Its Character and Origins," Oppositions 25 (1982): 23. 
necessary... Thus modern man sees a bit of himself in a monument, and he will react to every intervention as he would to one on himself."148

Riegl was right to make a connection between people and the buildings around them, but what he perhaps did not foresee was the effect of rather sudden deindustrialization on age-value and appreciation for ruins. When buildings constructed only a few decades before were rendered obsolete, the dynamic between people and ruins changed. Preservation became a way of arresting the flow of time in a rapidly shifting world and soon overpowered the romanticism of ruins. Professor Andreas Huyssen claims that, "The element of decay, erosion, and a return to nature so central to eighteenth-century ruins and their nostalgic lure is eliminated... when industrial ruins are made over into cultural centers; or when a museum like the Tate Modern installs itself in a decommissioned power plant..." though in fact the intense interest in remade industrial spaces like the Pratt Street Power Plant and the Camden Warehouse indicates that refurbishing the ruin does not destroy its nostalgic effect. ${ }^{149}$

In fact, the increase in America's nostalgia for the past has manifested itself primarily as a tendency towards preservation over ruination. As society surged forward, attitudes towards what buildings were worthy of being saved from the ravages of time began to change. Margaret Farrar shows how nostalgia impacted not only American attitudes, but the law of the land itself:

In the United States, treating our collective nostalgia for old places has become a matter of public policy. After two decades of observing intensive postwar clearing and suburban build-out, the United States Conference of Mayors argued in the 1966 report that as a result, the country was suffering from a "feeling of rootlessness." The historic preservation movement, the report continued, could provide American society with a much-needed

\footnotetext{
${ }^{148}$ Ibid., 32

${ }^{149}$ Huyssen, “Nostalgia for Ruins," 10.
} 
"sense of orientation" by using "structures and objects of the past to establish values of

time and place." The National Historic Preservation Act was passed shortly thereafter... ${ }^{150}$

With the passage of the National Historic Preservation Act, a whole new chapter in America's relationship with the past was opened up. Now the desire to revisit the past was a sanctioned part of the national government.

Since the 1960s, the American need to 'experience' the past through historic preservation has also increased. Heritage tourism is fast growing. There are over one million historic properties in the United States, and a 2004 study found that over $50 \%$ of people surveyed had visited a historic site in the last 12 months. As Margaret Farrar notes, “...Americans are nursing their geographic ennui by investing both their tax dollars and their discretionary income on the production and consumption of nostalgic landscapes..." but through the monetization of built heritage, especially in the case of adaptive reuse projects, the lines have begun to blur between the shopping mall and the museum. ${ }^{151}$

\section{Commoditizing the Past}

It is not fair to say that Baltimoreans are unaware of the extent to which the past has become a commodity in their city. One Baltimore Sun article on the Six Flags project for the power plant noted that "Any corporation coming in to exploit our heritage, nostalgia and pride had better have done its homework...," suggesting that the citizenry were simultaneously aware and wary of putting a price tag on Baltimore's history. ${ }^{152}$

\footnotetext{
${ }^{150}$ Margaret E. Farrar, “Amnesia, Nostalgia, and the Politics of Place Memory.” Politics Research Quarterly 64, no. 4 (2011): 728. Accessed March 25, 2013. doi: 10.1177/1065912910373553. 151 lbid.

152 "Six Flags in a One-Flag Town," The Baltimore Sun, January 1, 1983, A14.
} 
The phenomenon of turning historic buildings and areas into tourist-centric commercial enterprises is not unique to Baltimore. M. Christine Boyer wrote on a similarly nostalgic landscape in New York City for her essay "Cities for Sale: Merchandising History at South Street Seaport." Boyer is highly critical of the trend towards turning historic structures into commercial venues through adaptive reuse: "City after city discovers that its abandoned industrial waterfront or outmoded city center contains enormous tourist potential and refurbished it as a leisure-time spectacle and sightseeing promenade," resulting in a new type of city environment that relies on illusion and simulation to generate its character. ${ }^{153}$ Boyer's quotation applies directly to Baltimore, where a combination of new construction and adaptive reuse converted the dilapidated harbor area into a shopping and entertainment district. The success of the Inner Harbor relies, at least in part, on the nostalgia of residents and visitors alike, who are enticed by the industrial ethos of the waterfront. The historic buildings of the Inner Harbor area allow consumers to participate, fleetingly and for a price, in Baltimore's past.

According to Michael Sorkin, this propensity for turning heritage into a good to be bought and sold is one of the characteristics of "Cyburbia," a new form of city that lacks sensible connections between its spaces and relies on a generalization, control, and simulation to function in the modern world. ${ }^{154}$ The element of simulation is closely tied in with using, or possibly misusing, historicism and historic buildings:

...this new realm is a city of simulations...the city as theme park. This is nowhere more visible than in its architecture, in buildings that rely for their authority on images drawn from history, from a spuriously appropriated past that substitutes for a more exigent and examined present. In most American cities, the "historic" has become the only complicit

\footnotetext{
${ }^{153}$ M. Christine Boyer, "Cities for Sale: Merchandising History at South Street Seaport" in Variations on the Theme Park, Michael Sorkin, ed. (New York: Hill and Wang, 1992), 189.

154 Michael Sorkin, "Introduction," in Variations on the Theme Park, Michael Sorkin, ed. (New York: Hill and Wang, 1992), xii-xiv.
} 
official urban value. The result is that the preservation of the physical remnants of the historical city has superseded attention to the human ecologies that produced and inhabited them. ${ }^{155}$

The critiques leveled by Boyer and Sorkin are directed at redevelopment project very much like the ones undertaken in the adaptive reuse of the Camden Warehouse and the Pratt Street Power Plant. Indeed, in its first reincarnation as a Six Flags urban theme park, the power plant was very much guilty of turning history into a something resembling a glorified circus attraction.

However, the case of these two buildings in their current forms should be considered more carefully to determine if they are indeed to be listed among the "...nonplaces... without connection to the rest of the city or the past...filled with contemporary fantasies, colonized by wishful projections, and turned in spectacles of consumption" or if these two Baltimore landmarks have in any way broken the mode of simulation so reviled by scholars such as Sorkin and Boyer. ${ }^{156}$

\section{The Place of History}

In The Death and Life of Great American Cities, Jane Jacobs wrote that "Cities need old buildings so badly it is probably impossible for vigorous streets and districts to grow without them." 157 Writing as she was in the era of large scale urban renewal, which was responsible for the destruction of huge sections of historic fabric in America's cities, Jacobs was not advocating for the kind simulated heritage maligned by Sorkin and Boyer. Rather, Jacobs describes the successful city as one that understands how to mingle the new and the old. When The Death and Life of Great American Cities was first published in 1961, new construction was the realm of already established commercial endeavors that could afford the high-cost and risk potential of

\footnotetext{
155 Ibid., xiv.

156 Boyer, "Cities for Sale," 191.

157 Jane Jacobs, The Death and Life of Great American Cities (New York: Vintage Books, 1992), 187.
} 
new buildings. Older structures, on the other hand, tended to be cheaper and more available,

providing a place for less secure companies trying to make their way in the market. ${ }^{158}$

This is not to say that adaptive reuse was not a part of cities in the 1960s, but the kind of reuse projects Jacobs saw were more diversified than the historic tourist traps described in

\section{Variations on a Theme Park:}

Among the most admirable and enjoyable sights to be found along the sidewalks of big cities are the ingenious adaptations of old quarters to new uses. The town-house that becomes a craftsman's showroom, the stable that becomes a house, the basement that becomes an immigrants' club, the garage or brewery that becomes a theater, the beauty parlor that becomes the ground floor of a duplex, the warehouse that becomes a factory for Chinese food, the dancing school that becomes a pamphlet printers, the cobbler's that becomes a church with lovingly painted windows - the stained glass of the poor - the butcher shop that becomes a restaurant: these are the kinds of minor changes forever occurring where city districts have vitality and are responsive to human needs. ${ }^{159}$

The kind of transitions in use seen by Jacobs represented a broad spectrum of human activity and often occurred when local business began to utilize old space in a new way. Reuse defined by Jacobs does not rely on the brand recognition of chain retailers or heritage tourism to draw in their clientele. Rather they were simply businesses looking to take advantage of cheap and available real estate.

Baltimore's industrial waterfront never fit the bill for this kind of redevelopment. The buildings in the vicinity of the Inner Harbor, especially the warehouse and the power plant, were massive in scale and sited on valuable bayside real estate. They therefore required uses that went beyond the means of the majority of local business owners or other small corporations. Indeed, a primary factor in the failure of proposals for the Pratt Street Power Plant was a lack of available funding and the projects that finally did take root in these buildings were multi-million dollar

\footnotetext{
158 Ibid., 187-188.
}

159 Ibid., 194-195 
developments funded through public money in the case of Camden Yards and by private/public partnership in the case of the Pratt Street Power Plant. ${ }^{160}$

In cases such as the Camden Warehouse and the Pratt Street Power Plant, history, or at least the patina of history, does become part of the larger commercial endeavor. However, what is the alternative for buildings like this? As discussed above, costs to turn buildings of this size into viable businesses of any kind requires serious capitol, and even buildings that are turned into museums or other public enterprises require enormous funds gathered at the expense of the tax payer, as was the case at Camden Yards. Private commercial redevelopment is one of a very limited number of options for the great giants of the industrial age that have outlived their original use. That many of these buildings will ultimately become part of trendy commercial or residential redevelopment is probably inevitable. What is not inevitable, however, is the way in which the history of these spaces is reduced to exposed bricks and beams and other vague symbols of the industrial past.

Part of the problem with keeping the history alive in adaptive reuse projects is the emphasis placed on the exterior façade over the rest of the building. Tax credit and grant programs often require only external integrity and make few, if any, demands on the interpretive quality of the buildings new use. The physical attributes of a building are important, but, as architectural historian and preservationist Daniel Bluestone calls for in his essay, Tobacco Row, we also need to "...weigh more than simply what happens to buildings exteriors. We need to consider the extent to which these projects encourage a capacity for critical reflections on the

\footnotetext{
160 Timothy S. Chapin, "Sports Facilities as Urban Redevelopment Catalysts: Baltimore's Camden Yards and Cleveland's Gateway," Journal of the American Planning Association 70, no. 2 (2004): 199. Accessed December 2, 2013.
} 
histories associated with particular places." ${ }^{161}$ If adaptive reuse is partly responsible for turning American cities into theme parks, the key to reclaiming a sense of place lies in putting emphasis on history instead of pandering to the yearnings of a nostalgic nation.

Inclusion of exhibits and other materials to give visitors of the importance of these places in Baltimore's history would go a long way to bridge the disconnect between the trendy elements of industrial remains found in the warehouse and the power plant, and the actual story behind these buildings' many years as working pieces of Baltimore's industrial landscape. True, visitors to the Barnes \& Noble Bookstore in the central boiler house of the power plant will find some historic photographs and partial newspaper clippings increased to poster-scale and mounted above the magazine section (Fig. 3.1). However, this display is not in a very prominent position in the bookstore and even for the close observer it only reveals fairly little information. A careful study of the display connects the power plant with the United Railways \& Electric Company and to streetcars, but doesn't do anything to place the structure within the larger historic infrastructure of Baltimore and the role streetcars played in the city's development (Fig. 3.2). Additionally, though some of the images are clearly taken from newspaper clippings, artistry overtakes history in the display and most of the text is cut off or cropped out rendering it unintelligible.

Camden Yards also lacks historical interpretation. The warehouse and Camden Station are all that survive of the original $\mathrm{B} \& \mathrm{O}$ railyard and these two buildings provide a chance to interpret the history of the site. However, little has been done to take advantage of the opportunity to explore some very interesting parts of Baltimore's past through the buildings of

\footnotetext{
161 Bluestone, “Tobacco Row,” 134.
} 
Camden Yards. ${ }^{162}$ In recent years, a Civil War Trails interpretive panel has been added next to Camden Station explaining that the station was the site of a riot at the very start of that conflict (Fig. 3.3) and in the spring of 2013 a plaque went up to commemorate the labor strike of 1877 (Fig. 3.4) ${ }^{163}$ Both of these interpretative efforts center around Camden Station and focus on events that predate the warehouse, leaving it wholly without any kind of marker to identify it or place it in any kind of historical context.

Furthermore, the full history of these buildings is almost always superseded in scholarly works by their present status as part of Baltimore's downtown revitalization. Important though this more recent period in their history is, it is but a small part of the story. There are virtually no opportunities for the casual observer of the Inner Harbor to discover that the place where they bought the latest best-selling book once powered most of the city's streetcars, or to find out that the brick building they meandered through on their way to the ballgame was designed to hold one-thousand boxcars.

Facts like these may not have the dramatic panache of a 3D light show, but they serve a vital purpose. They connect these reused buildings back to Baltimore's past and begin to form a link between the city's present inhabitants and those who came before them. A little bit of history goes a long way to turn just another industrial reuse project into something particular, something that you can't find just anywhere. History goes beyond the nostalgic and begins to engage people who just came out to grab a crab cake or catch an afternoon baseball game with the stories of the places they inhabit.

\footnotetext{
162 Donovan, “Nostalgia and Tourism: Camden Yards in Baltimore," 229-234.

163 Fern Shen, "Epic railroad strike remembered with new Camden Yards plaque," Baltimore Brew, March 24, 2013, accessed December 10, 2013, url: <http://www.baltimorebrew.com/2013/03/24/epic-railroad-strikeremembered-with-new-camden-yards-plaque/>
} 


\section{Conclusion}

Over the course of the twentieth century, both the Camden Warehouse and the Pratt Street Power Plant underwent an evolutionary process that shifted their place in Baltimore's downtown landscape. These buildings were the height of industrial sophistication at the time of their construction and, in their original period of construction, any elegance of design ascribed to them was more closely related to function than to aesthetics. Their minimal decorative features were a part of the emerging importance of the industrialists' public image in the waning years of the nineteenth century. As serious investments of time and money, and as representative of their respective industries, both the Camden Warehouse and the Pratt Street Power Plant stood as symbols of the power of industry at the turn-of-the-century.

Additionally, both buildings were part of railway companies that played major roles in the development of Baltimore and its infrastructure. The consolidation of the city's streetcar companies under United Railway \& Electric and the centralization of power production at the Pratt Street Power Plant opened up the suburbs and radically altered the way people moved around the city. While the streetcars increased mobility on a local level, the Baltimore \& Ohio Railroad expanded westward on a national scale, linking the American frontier to the coast and making Baltimore a hub of transportation and travel. The Camden Warehouse was a sign of the prosperity of the $\mathrm{B} \& \mathrm{O}$, as only a company experiencing great success could afford to build the longest building on the east coast, or, for that matter, require such extensive storage capacity in a single location.

Despite their central place in Baltimore's development in the early years of the twentieth century, the journey through the next several decades was difficult for these monuments of 
industry, as Baltimore faced deindustrialization and the various problems produced by that process. These buildings and the companies that built them were partly responsible for creating the modern world, a world which eventually made them obsolete. Modernization turned on them and rendered them useless old relics of a bygone era, overtaken by the rise of the automobile and then the disappearance of American industry. Still, the buildings endured and a dramatic shift began to occur in American culture that ultimately saved these buildings: a burgeoning nostalgia for the past. Though, as demonstrated in the second and third chapters of this work, the path to new uses for old buildings is seldom a smooth one, especially in the case of large and valuable waterfront properties.

Though both buildings eventually became part of the city's massive downtown redevelopment, they continue to be neglected by historians. Too often in the books that detail Baltimore's architectural history the Camden Warehouse and the Pratt Street Power Plant are given only a cursory glance and perhaps a mention of one or two sentences. Here, I believe for the first time, is a truly thorough history of both these buildings, from initial construction to the present day, compiled and presented for consideration. The purpose of such an exercise is to show how these two buildings played an important role in Baltimore from their original incarnations to their present forms. They are more than a power plant and a warehouse. These buildings were parts of companies that changed Baltimore in radical ways in the nineteenth and early twentieth centuries, and now they are some of the last remains of an era in the city's history that ceased to exist long ago. They are not just a ballpark, a bookstore, or a restaurant with an unusual façade. They are monuments to the industrial past.

The extent to which the warehouse or the power plant engage this history in their present forms is minimal. Though not, I think, as overtly faux-historic as some similar developments 
(such as the South Street Seaport much maligned by Boyer), the history behind these buildings and their broader place in Baltimore's story is largely ignored. Increased awareness of the storied past of these structures would not be difficult to generate, and could even be accomplished fairly well through the use of historical markers. Making history available to visitors restores some of the context that has been erased by time and the sanitizing effects of adaptive reuse, turning these buildings back into something that has meaning for the citizens of Baltimore.

History cannot, of course, solve Baltimore's problems. It must be acknowledged that some of the issues that trouble that city are only exacerbated by the development of the Inner Harbor and the switch to a service economy. The Camden Warehouse and the Pratt Street Power Plant are part of changes that have impacted the city, both negatively and positively. Perhaps more importantly, however, they have stood as witnesses to the history of Baltimore, through fire, economic crisis, deindustrialization and the coming of the new millennium. They are the survivors, great emblems of the spirit of a city that continues to fight for a better future. In that respect they are more than monuments of industry, or even monuments or nostalgia. Rather, they are monuments to the continuing endurance of Baltimore and its citizens. 
Bibliography

“A BIG SCHEME IF TRUE: Speculative Rumors About the Possibilities of Railway Consolidation." The Baltimore Sun, February 10, 1888. Accessed February 7, 2014 via ProQuest Historical Newspapers.

"A Cathedral of Power from Yesteryear." The Baltimore Sun, February 18, 1979. Accessed February 7, 2014 via ProQuest Historical Newspapers.

"A GREAT POWER-HOUSE: Property Purchased by City and Suburban Railway." The Baltimore Sun, November 2, 1892. Accessed February 7, 2014 via ProQuest Historical Newspapers.

Alexander, Jeffrey C., Dominik Bartmański, and Bernhard Giesen. Iconic Power: Materiality and Meaning in Social Life. New York: Palgrave Macmillan, 2012.

Avery, Carlos P. E. Francis Baldwin, Architect: The B\&O, Baltimore, and Beyond. Baltimore: Baltimore Architecture Foundation, 2003.

Banisky, Sandy. "Camden complex planned: Zoning requested for stores, offices in old warehouse." The Baltimore Sun, September 29, 1983. Accessed February 7, 2014 via ProQuest Historical Newspapers.

Banisky, Sandy. "Six Flags likely to earn city $\$ 1.5$ million a year." The Baltimore Sun, June 30, 1983. Accessed February 7, 2014 via ProQuest Historical Newspapers.

Bloom, Nicholas Dagen. Merchant of Illusion: James Rouse, America's Salesman of the Businessman's Utopia. Columbus: The Ohio State University Press, 2004.

Bluestone, Daniel. "Tobacco Row: Heritage, Environment, and Adaptive Reuse in Richmond, Virginia." Change Over Time, vol. 2, no. 2 (2012): 132-154.

Boeckelman, Keith. "The American States in the Postindustrial Economy." State \& Local Government Review 27, no. 3 (1995): 182-187. Accessed February 19, 2014. url: <http://www.jstor.org/stable/4355128>

Boym, Svetlana. The Future of Nostalgia. New York: Basic Books, 2001.

Bradley, Betsy Hunter. The Works: The Industrial Architecture of the United States. New York and Oxford: Oxford University Press, 1999.

Buchard, Hank. "Watt's New? The Power Plant." The Washington Post, July 26, 1985. Accessed July 7, 2013 via ProQuest Historical Newspapers.

"CAMDEN STATION WAREHOUSE: Contract For The Building Awarded to Henry Smith \& Sons - A Great Structure." The Baltimore Sun, January 11, 1899. Accessed February 7, 2014 via ProQuest Historical Newspapers.

"CARS TIED UP: 25 Men At Powerhouse Quit At 4:45 P. M. and Thousands Walk." The Baltimore Sun, February 12, 1907. Accessed February 7, 2014 via ProQuest Historical Newspapers.

Chapin, Timothy S. "Sports Facilities as Urban Redevelopment Catalysts: Baltimore's Camden Yards and Cleveland's Gateway." Journal of the American Planning Association 70, no. 2 (2004): 193-209. Accessed December 2, 2013.

Cook, Hugh. "Powered by retail." Building Design \& Construction 40, no. 8 (1999): 1-4. Accessed October 29, 2012.

EIR Economics Staff, “The Case of Baltimore: Deindustrialization Creates 'Death Zones,' Executive Intelligence Review (2006):4-20. url: 
<https://www.google.com/search?q=eir+economics\&oq=EIR+econ\&aqs=chrome.1.69i57j013.2732j0j7\&sourcei $\mathrm{d}=$ chrome\&espv=210\&es_sm=122\&ie=UTF-8>

Evans, Judith. "Disney Does a Deal at Baltimore's Inner Harbor." The Washington Post, October 15, 1997. Accessed March 2, 2014 via ProQuest Historical Newspapers.

Farrar, Margaret E. “Amnesia, Nostalgia, and the Politics of Place Memory." Politics Research Quarterly 64, no. 4 (2011): 723-735. Accessed March 25, 2013. doi: 10.1177/1065912910373553.

Federal Bureau of Investigation. “FBI Uniform Crime Report 2011: Violent Crime." Accessed December 11, 2012. url: <http://www.fbi.gov/about-us/cjis/ucr/crime-in-the-u.s/2011/crime-in-the-u.s.-2011/violent-crime/violentcrime>

Forstall, Richard L. "MARYLAND - Population of Counties by Decennial Census: 1900 to 1990." Accessed April 21, 2013. url: <http://www.census.gov/population/cencounts/md190090.txt>

Franch, Michael S., "Camden Station: Vivid Past, Cloudy Future." The Baltimore Sun, March 16, 1975. Accessed February 7, 2014 via ProQuest Historical Newspapers.

Friedman, Michael T., David L. Andrews, and Michael L. Silk. "Sport and the Façade of Redevelopment in the Postindustrial City." Sociology of Sport Journal 21 (2004): 119-139. Accessed January 27, 2014.

Gibson, Campbell. "Population of the 100 Largest Cities and Other Urban Places in the United States: 1790 to 1990." U.S. Bureau of the Census Population Division Working Paper No. 27 (June 1998). Accessed via U.S. Census Bureau. url: <http://www.census.gov/population/www/documentation/twps0027/twps0027.html>

Gildea, William. "It's a Grand Opening for Camden Yards." The Washington Post, April 7, 1992. Accessed March 1, 2014 via ProQuest Historical Newspapers.

"Great Baltimore Fire of 1904." Maryland Digital Cultural Heritage Project, Enoch Pratt Free Library. Last modified 2004. <http://www.mdch.org/fire/\#>

Gunts, Edward. "Old warehouse may be made part of stadium site." The Baltimore Sun, December 28, 1988. Accessed February 7, 2014 via ProQuest Historical Newspapers.

Gunts, Edward. "Six Flags to sell its lease on Power Plant." The Baltimore Sun, August 29, 1987. Accessed February 7, 2014 via ProQuest Historical Newspapers.

"Harbor sites weighed: Historical unit studies new maritime museum." The Baltimore Sun, November 21, 1976. Accessed February 7, 2014 via ProQuest Historical Newspapers.

Harness, C. Bryan. Interview by Virginia Harness. Lynchburg, Virginia. April 25, 2014.

Harvey, David. Spaces of Hope. Berkeley and Los Angeles: University of California Press, 2000.

Harwood, Herbert H. Impossible Challenge: The Baltimore and Ohio Railroad in Maryland. Baltimore: Barnard, Roberts and Company, Inc., 1979.

Hayward, Mary Ellen. Baltimore's Alley Houses: Homes for Working People Since the 1780s. Baltimore: Johns Hopkins University Press, 2008.

Hayward, Mary Ellen and Charles Belfoure. The Baltimore Rowhouse. New York: Princeton Architectural Press, 1999. 
Hayward, Mary Ellen and Frank R. Shivers, Jr., eds. The Architecture of Baltimore: An Illustrated History. Baltimore and London: The Johns Hopkins University Press, 2004.

Helton, Gary. Baltimore's Streetcars and Buses. Images of America. Charleston: Arcadia Publishing, 2008.

High, Steven and David W. Lewis. Corporate Wasteland: The Landscape and Memory of Deindustrialization. Ithaca and London: Cornell University Press, 2007.

Hobsbawn, Eric and Terence Ranger, eds. The Invention of Tradition. Cambridge: Cambridge University Press, 1992.

Hopkins, Jamie Smith. "ESPN Zone workers, employer reach settlement." The Baltimore Sun, November 3, 2013. Accessed March 2, 2014. url: <http://www.baltimoresun.com/business/bs-bz-espn-zone-settlement20131101,0,2820437.story>

Huyssen, Andreas. “Nostalgia for Ruins.” Grey Room 23 (2006): 6-21.

"IMPROVING POWER STATION: Experts Give Suggestions And Work Will Begin At Once." The Baltimore Sun, August 18, 1906. Accessed February 14, 2014 via ProQuest Historical Newspapers.

Jacobs, Jane. The Death and Life of Great American Cities. New York: Vintage Books, 1992.

Kaltenbach, Chris and Jill Rosen. "Phillips Seafood, the last of the original Harborplace tenants, to close." The Baltimore Sun, June 10, 2011. Accessed March 2, 2014. url:

<http://www.baltimoresun.com/entertainment/dining/baltimore-diner-blog/bal-phillips-to-close-harborplacelocation-20110610,0,4719307.story>

Kemp, Emory L. and Theodore Anton Sande. Historic Preservation of Engineering Works: Proceedings of an Engineering Foundation Conference Held at Franklin Pierce College, Rindge, New Hampshire, June 25-30, 1978. New York: American Society of Civil Engineers, 1978.

Kidney, Walter C. Working Places: The Adaptive Reuse of Industrial Buildings, a handbook sponsored by the Society for Industrial Archaeology. Pittsburgh: Ober Park Associates, Inc., 1976.

Kohn, Margaret. "Toronto's Distillery District: Consumption and Nostalgia in a Post-Industrial Landscape." Globalizations 7, no. 3 (2010): 359-369. Accessed March 20, 2013. doi: 10.1080/14747731003669735.

Lapoint, George M. "The history and development of the Pratt Street Power Plant of the Baltimore Consolidated Gas Electric Light and Power Company." Records of Phi Mu, Special Collections, University of Maryland Libraries, 1925.

Loverro, Thom. Home of the Game: The Story of Camden Yards. Dallas, Texas: Taylor Publishing, 1999.

Lynton, Stephen J. "New Magic in Store of Old Power Plant." The Washington Post, January 17, 1983. Accessed July 7, 2013 via ProQuest Historical Newspapers.

Marshall, Richard, ed. Waterfronts in Post-Industrial Cities. London and New York: Spoon Press, 2001.

"New Power Plant for Baltimore: Special to The New York Times." The New York Times, November 3, 1904. Accessed July 7, 2014 via ProQuest Historical Newspapers.

National Register of Historic Places. Pratt Street Power Plant. Baltimore, Maryland. National Register \# 87000564. Accessed April 25, 2014 via Maryland Inventory of Historic Properties. url: 
<http://www.mdihp.net/dsp_search.cfm?search=address\&id=40226\&viewer=true\&updated=Y\&criteria1=A\&cri teria2 $=\mathrm{AL}>$

Olson, Sherry L. Baltimore: The Building of an American City. Baltimore: The Johns Hopkins University Press, 1980.

Potts, Mark. "Camden Yards: Baltimore's New Diamond Is a Gold Mine." The Washington Post. July 5, 1992. Accessed March 1, 2014 via ProQuest Historical Newspapers.

Richmond, Peter. Ballpark: Camden Yards and the Building of an American Dream. New York: Simon \& Schuster, 1993.

Riegl, Alois. "The Modern Cult of Monuments: Its Character and Origins," Oppositions 25 (1982): 20-51.

Rosenweig, Daniel. Retro Ball Parks: Instant History, Baseball, and the New American City. Knoxville: The University of Tennessee Press, 2005.

Salamon, Stephen J., David P. Oroszi, and David P. Ori. Baltimore and Ohio: Reflections of the Capitol Dome New York to Cumberland. Silver Spring: Old Line Graphics, 1993.

Sanborn-Perris Map Company Limited. Insurance Maps of Baltimore, Maryland Vol. 1. Map. New York: The Sanborn-Perris Map Co. Limited, 1890. Accessed February 18, 2014 via ProQuest Digital Sanborn Maps. url: $<$ http://sanborn.umi.com.proxy.its.virginia.edu/md/3573/dateid-000001.htm?CCSI=302n>

Sanborn-Perris Map Company Limited. Insurance Maps of Baltimore, Maryland Vol. 1. Map. New York: The Sanborn-Perris Map Co. Limited, 1901. Accessed February 18, 2014 via ProQuest Digital Sanborn Maps. url: <http://sanborn.umi.com.proxy.its.virginia.edu/md/3573/dateid-000004.htm?CCSI=302n>

Seiden, Matt. “Does Baltimore want Six Flags' plasticized version of history?” The Baltimore Sun, January 7, 1983. Accessed February 7, 2014 via ProQuest Historical Newspapers.

Shackel, Paul A., ed. Myth, Memory, and the Making of the American Landscape. Gainesville: University Press of Florida, 2001.

Sharoff, Robert. "Redevelopment Enriching Baltimore's Inner Harbor: Power Plant to get glass wall to show interior smokestacks." The New York Times, August 3, 1997. Accessed March 2, 2014 via ProQuest Historical Newspapers.

Shen, Fern. "Epic railroad strike remembered with new Camden Yards plaque." Baltimore Brew, March 24, 2013. Accessed December 10, 2013. url: <http://www.baltimorebrew.com/2013/03/24/epic-railroad-strikeremembered-with-new-camden-yards-plaque/> 
Simon, David, creator. The Wire.Television series. Baltimore: Home Box Office, 2002-2008.

"Six Flags Corp. Vows to Succeed at Power Plant." The Washington Post, March 24, 1986. Accessed July 7, 2013 via ProQuest Historical Newspapers.

"Six Flags in a One-Flag Town." The Baltimore Sun, January 1, 1983. Accessed February 7, 2014 via ProQuest Historical Newspapers.

Smith, C. Fraser. "Plan would make bleak Camden yards a \$170 million living-working complex." The Baltimore Sun, May 23, 1979. Accessed February 7, 2014 via ProQuest Historical Newspapers.

Sorkin, Michael, ed. Variations on a Theme Park: The New American City and the End of Public Space. New York: Hill \& Wang, 1992.

"STREET CARS STOPPED: Accident At Power House Causes All-Night Tie-Up." The Baltimore Sun, April 29, 1906. Accessed February 7, 2014 via ProQuest Historical Newspapers.

"THE B. \& O. TO BUILD: Addition to Terminal Warehouse at Camden Station." The Baltimore Sun, August 2, 1904.Accessed February 7, 2014 via ProQuest Historical Newspapers.

“THE UNITED'S TIE-UP ON MONDAY.” The Baltimore Sun, February 13, 1907. Accessed February 7, 2014 via ProQuest Historical Newspapers.

Thomas, Selma, ed. Rehabilitation: An Alternative for Historic Industrial Buildings. Washington, D.C.: Historic American Engineering Record Office of Archeology and Historic Preservation Heritage Conservation and Recreation Service U.S. Department of the Interior, 1978.

"TO PREVENT "TIE-UPS" New York Experts Examine Pratt Street Power House." The Baltimore Sun, August 15, 1906. Accessed February 7, 2014 via ProQuest Historical Newspapers.

"UNITED IN NEW DEAL FOR PERPETUAL POWER: Contract With Consolidated Involved Sale of Pratt Street Power House." The Baltimore Sun, January 13, 1921. Accessed February 7, 2014 via ProQuest Historical Newspapers.

Uzelac, Ellen. "Six Flags closing Power Plant, going disco: New night spot wil feature live music, food." The Baltimore Sun, January 7, 1987. Accessed February 7, 2014 via ProQuest Historical Newspapers.

Vicino, Thomas J. Transforming Race and Class in Suburbia: Decline in Metropolitan Baltimore. New York: Palgrave Macmillan, 2008.

Zembala, Dennis M., ed. Baltimore: Industrial Gateway on the Chesapeake Bay. Baltimore: The Baltimore Museum of Industry, 1995. 


\section{Illustrations}

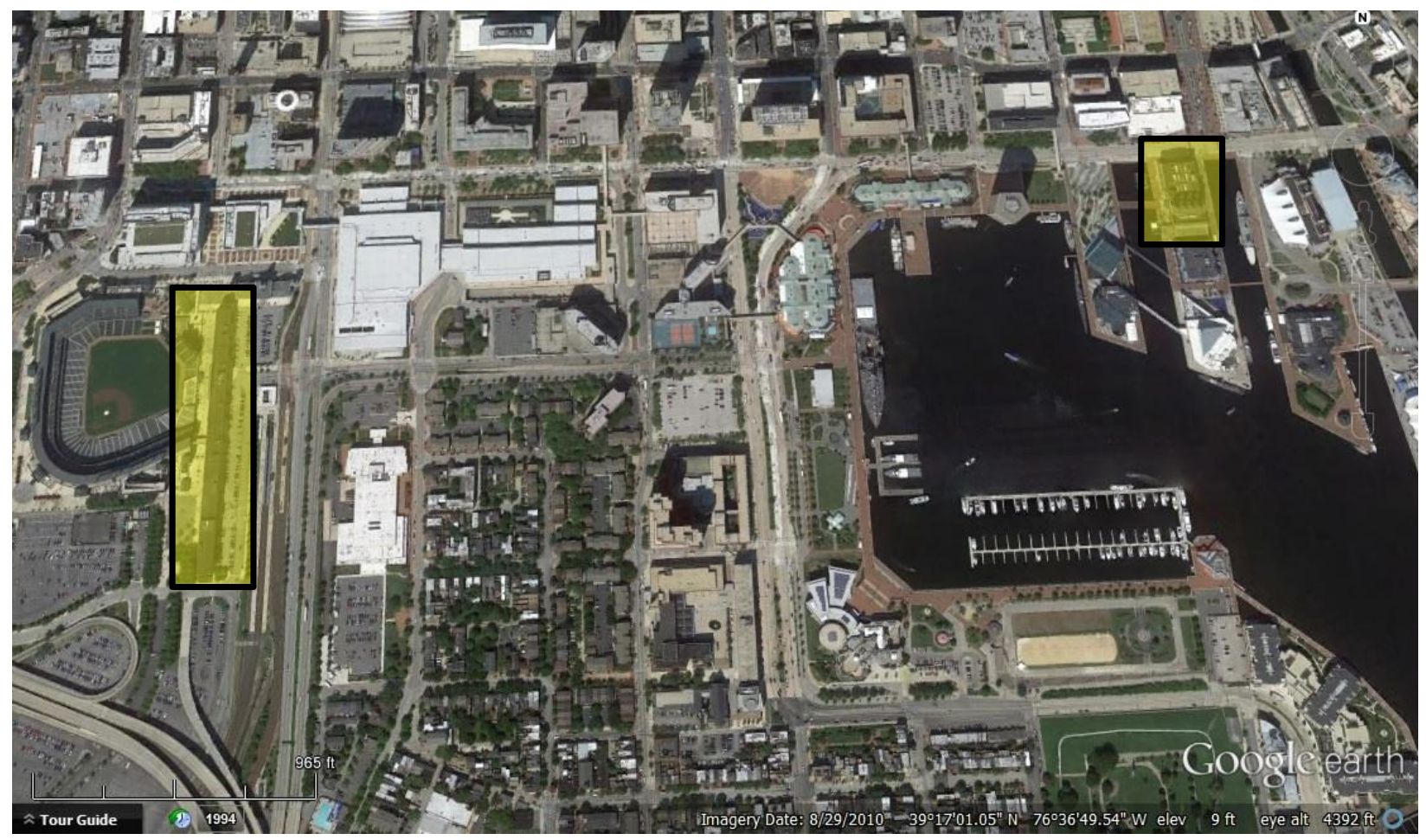

Fig. i.1 Aerial view of Baltimore's Inner Harbor area with the Camden Warehouse (left) and Pratt Street Power Plant highlighted. Source: Google Earth, August 29, 2010.

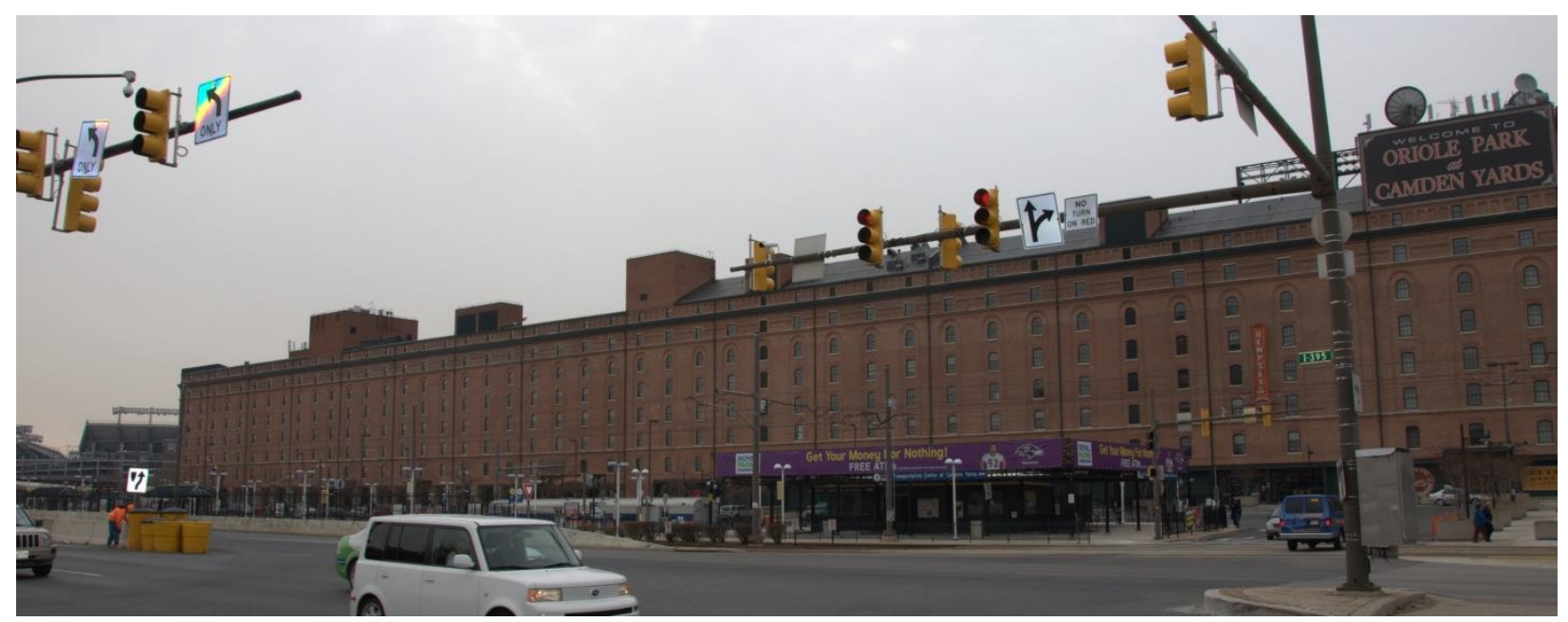

Fig. i.2 Camden Warehouse from the intersection of S. Howard Street and W. Conway Street. Source: Virginia Harness, February 8, 2014, Baltimore, MD. 


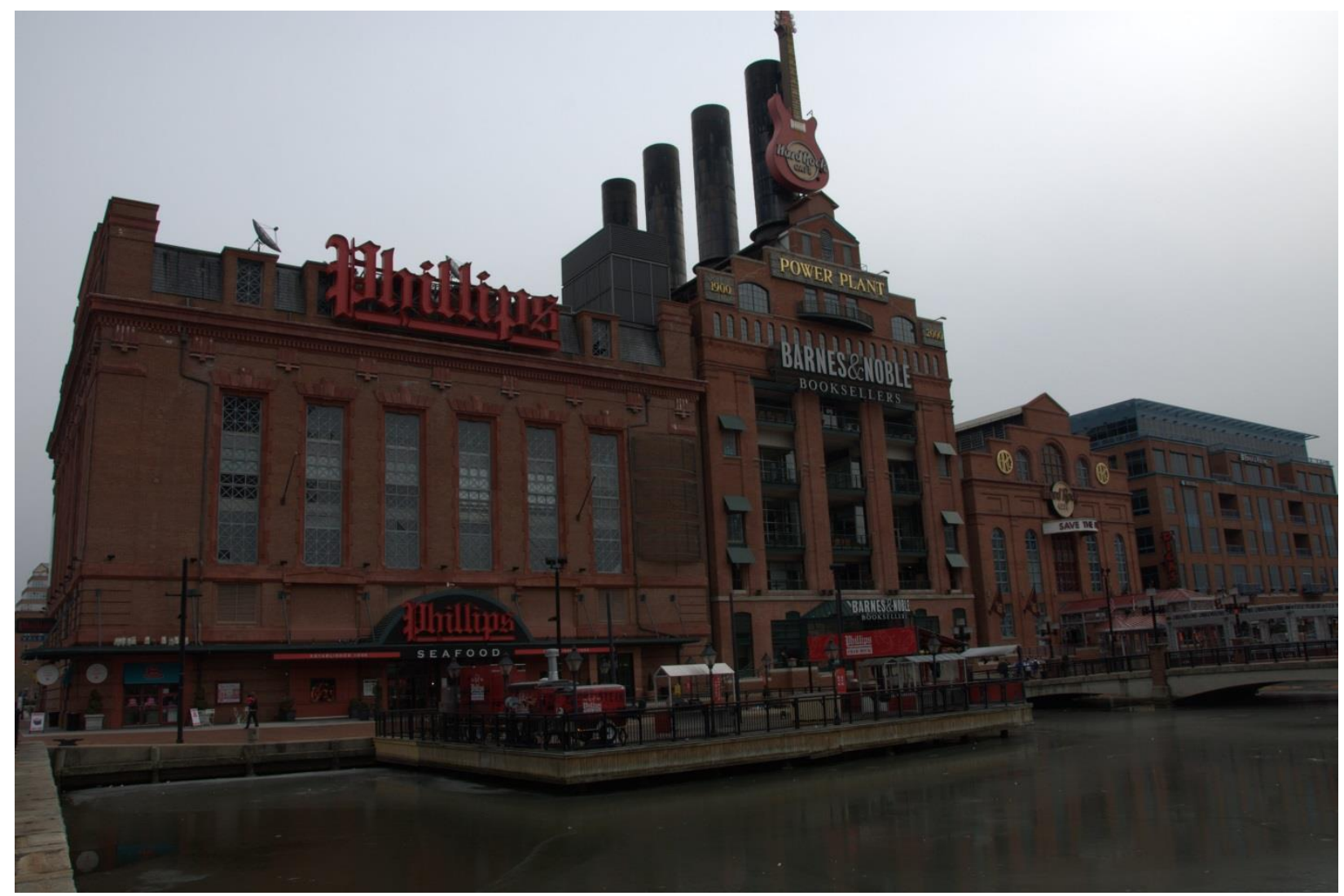

Fig. i.3 West façade of The Pratt Street Power Plant. Source: Virginia Harness, February 8, 2014, Baltimore, MD.

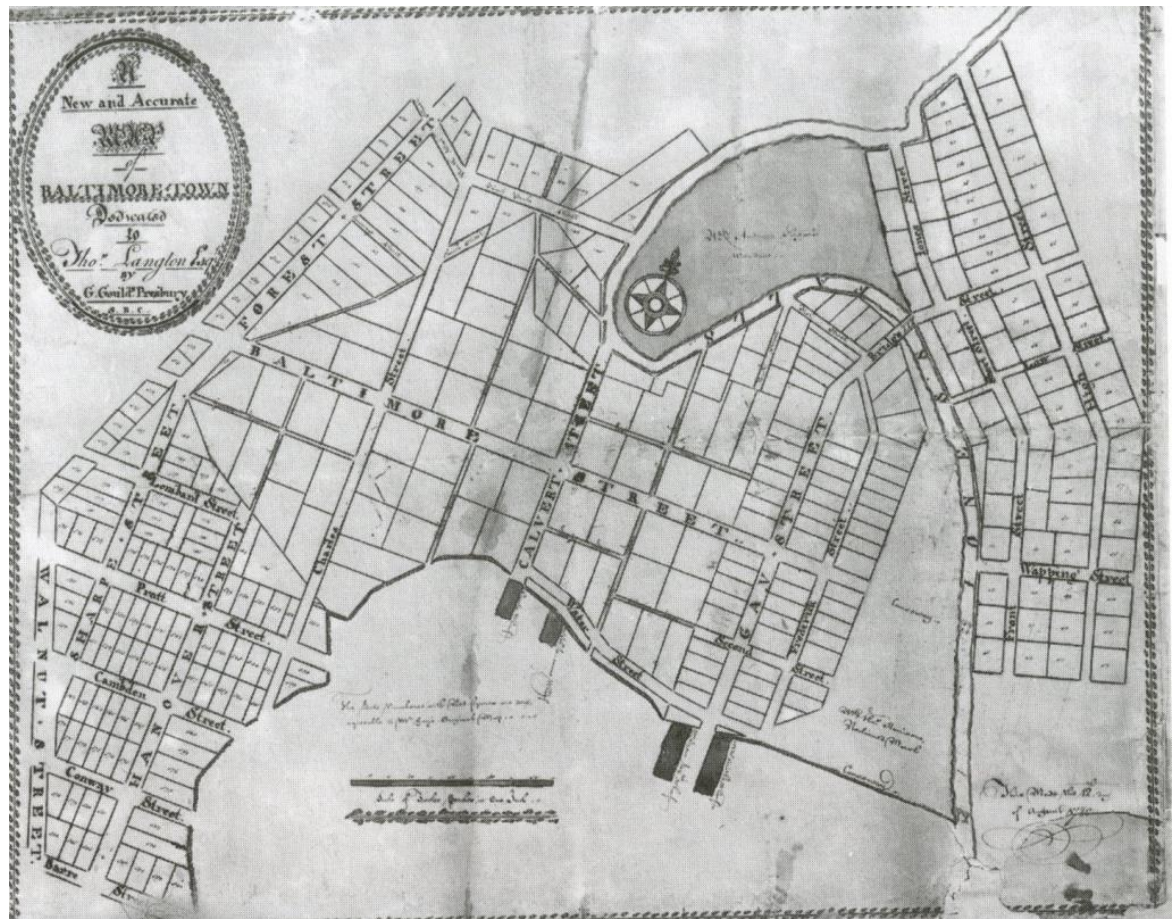

Fig. 1.1 G. Gould Presbury, A New and Accurate Map of Baltimore Town, 1780. The Maryland Historical Society. Source: Hayward, Architecture of Baltimore, 3. 


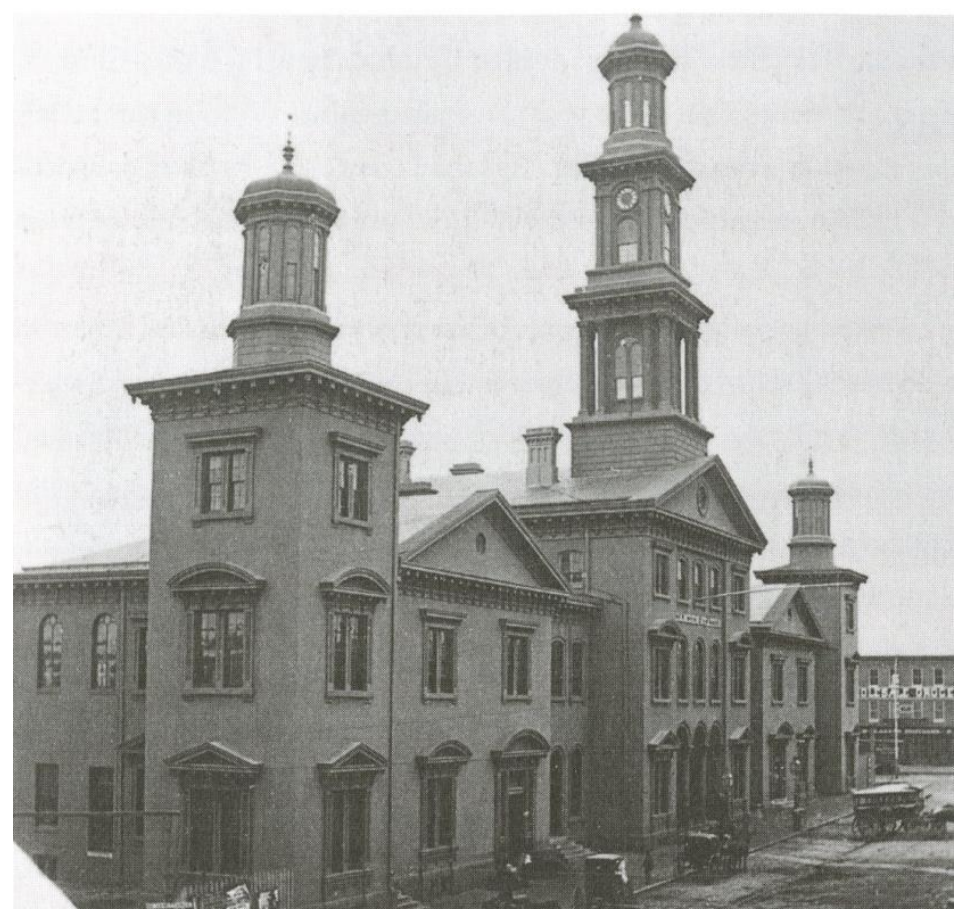

Fig. 1.2 Camden Station of the Baltimore \& Ohio Railroad, c.1871. The B\&O Railroad Museum, Inc. Source: Hayward, Architecture of Baltimore, 164.

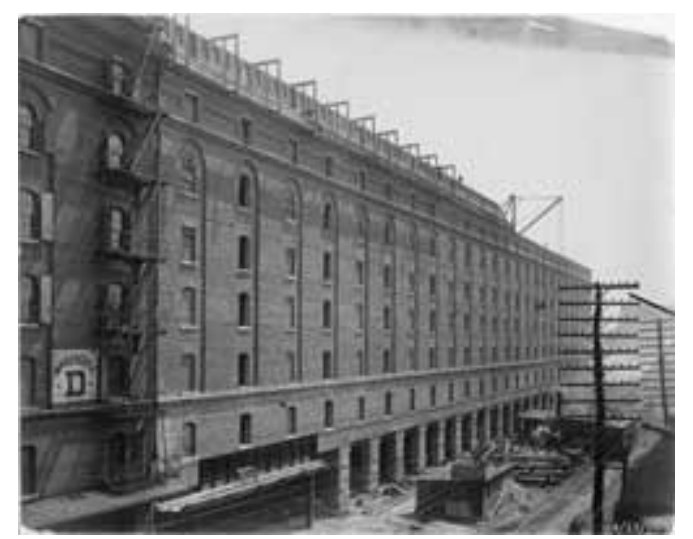

Fig. 1.3 James Stewart \& Company, Baltimore \& Ohio Railroad's terminal warehouse, 1905. James F. Hughes Company; James Stewart Construction Collection of the National Building Museum.

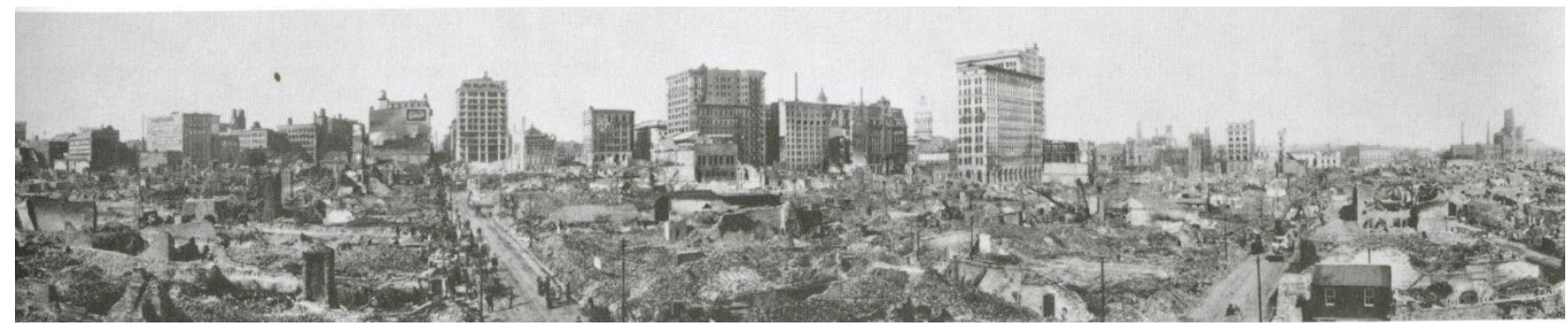

Fig. 1.4 Baltimore's business district following the great fire of 1904. Maryland Historical Society. Source: Hayward, Architecture of Baltimore, 237. 


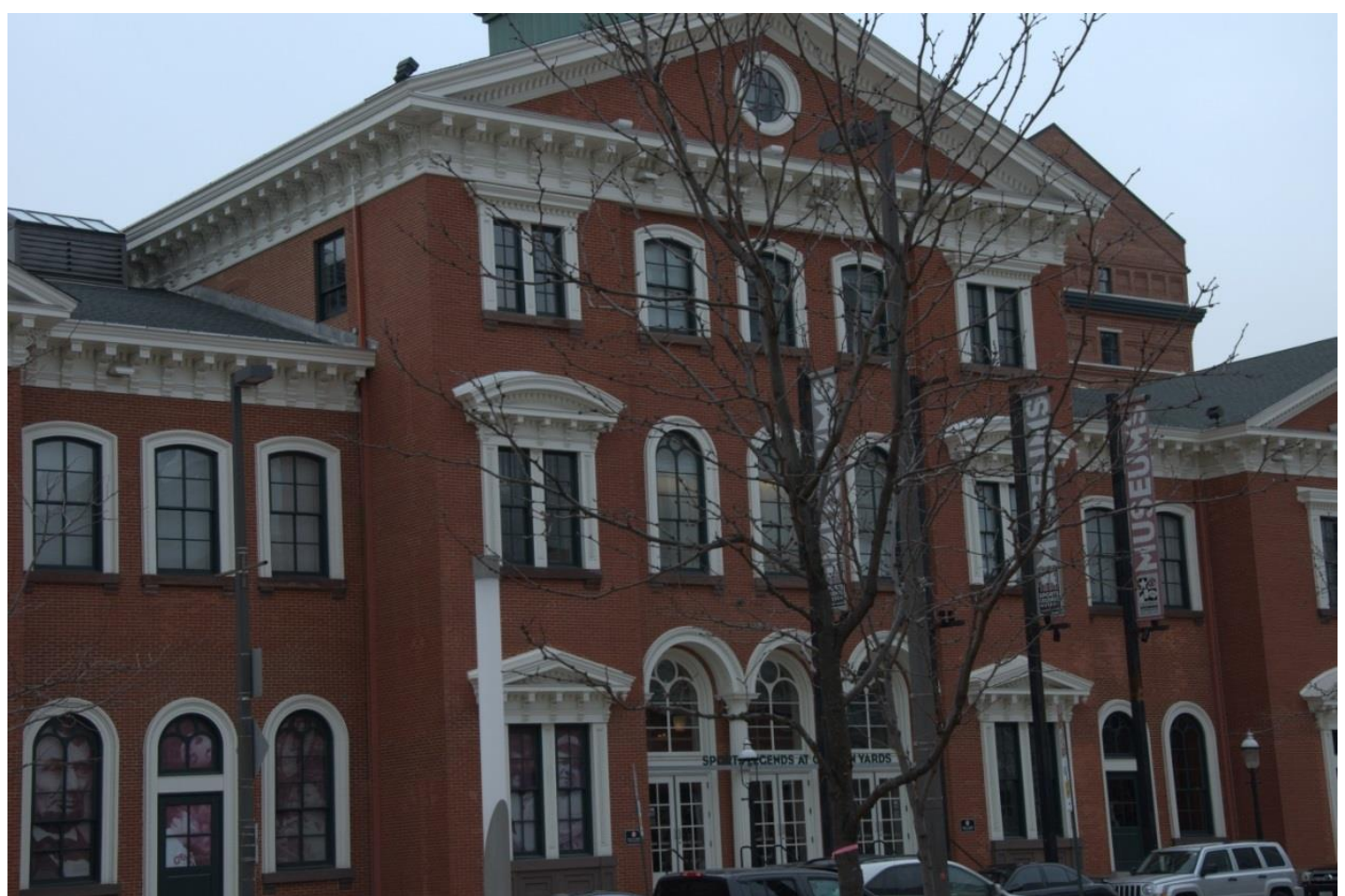

Fig. 1.5 Italianate details on the front façade of the restored Camden Station as seen in 2014. Source: Virginia Harness, February 8, 2014, Baltimore, MD.

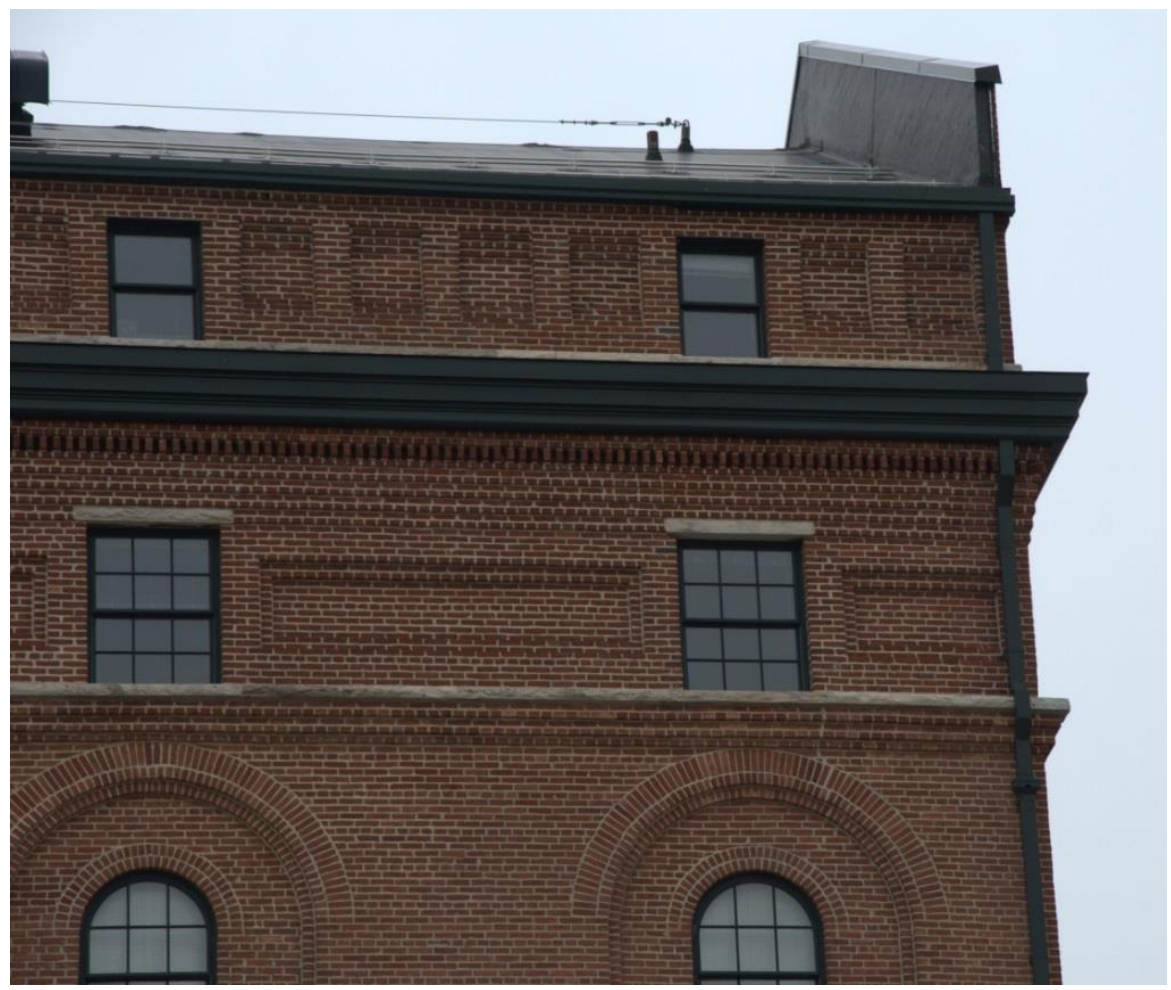

Fig. 1.6 Detail showing decorative brickwork on the Camden Warehouse. Source: Virginia Harness, February 8, 2014, Baltimore, MD. 


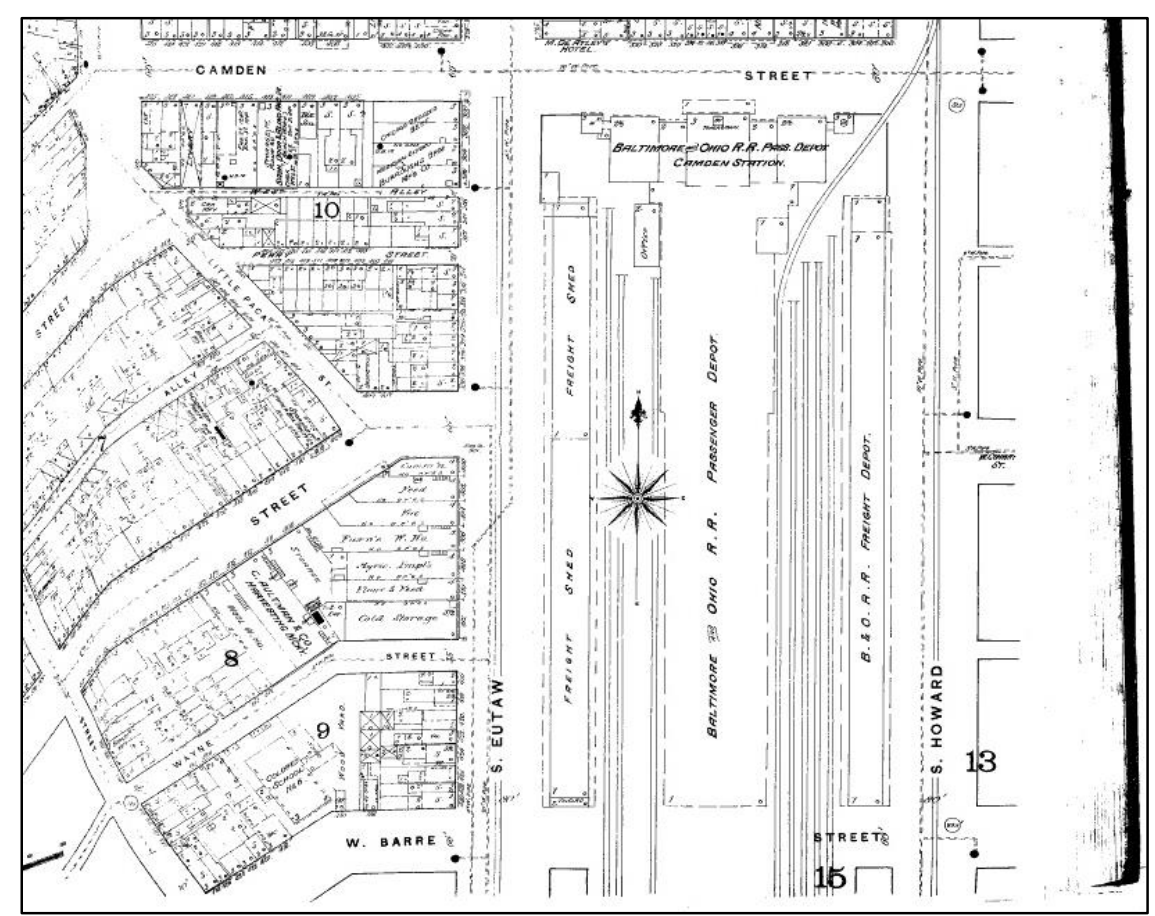

Fig. 1.7 "Baltimore, Maryland." 1890. Sanborn Fire Insurance Maps, 1867-1970 - Maryland. Source: Sanborn-Perris Map Company Limited, Insurance Maps of Baltimore, Maryland Vol. 1, map, 14b.

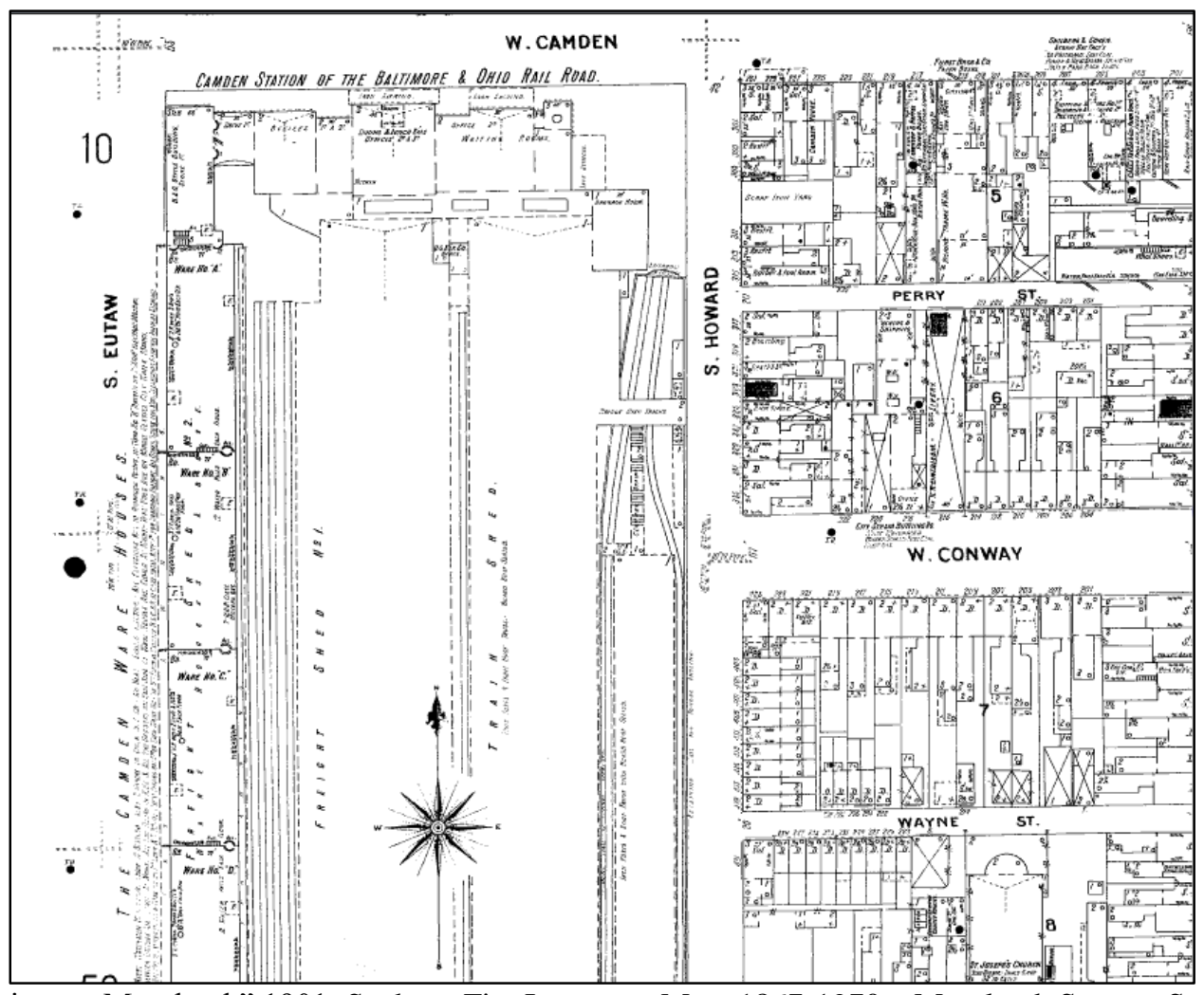

Fig. 1.8 "Baltimore, Maryland.” 1901. Sanborn Fire Insurance Map, 1867-1970 - Maryland. Source: Sanborn-Perris Map Company Limited, Insurance of Baltimore, Maryland Vol. 1, map, 11. 


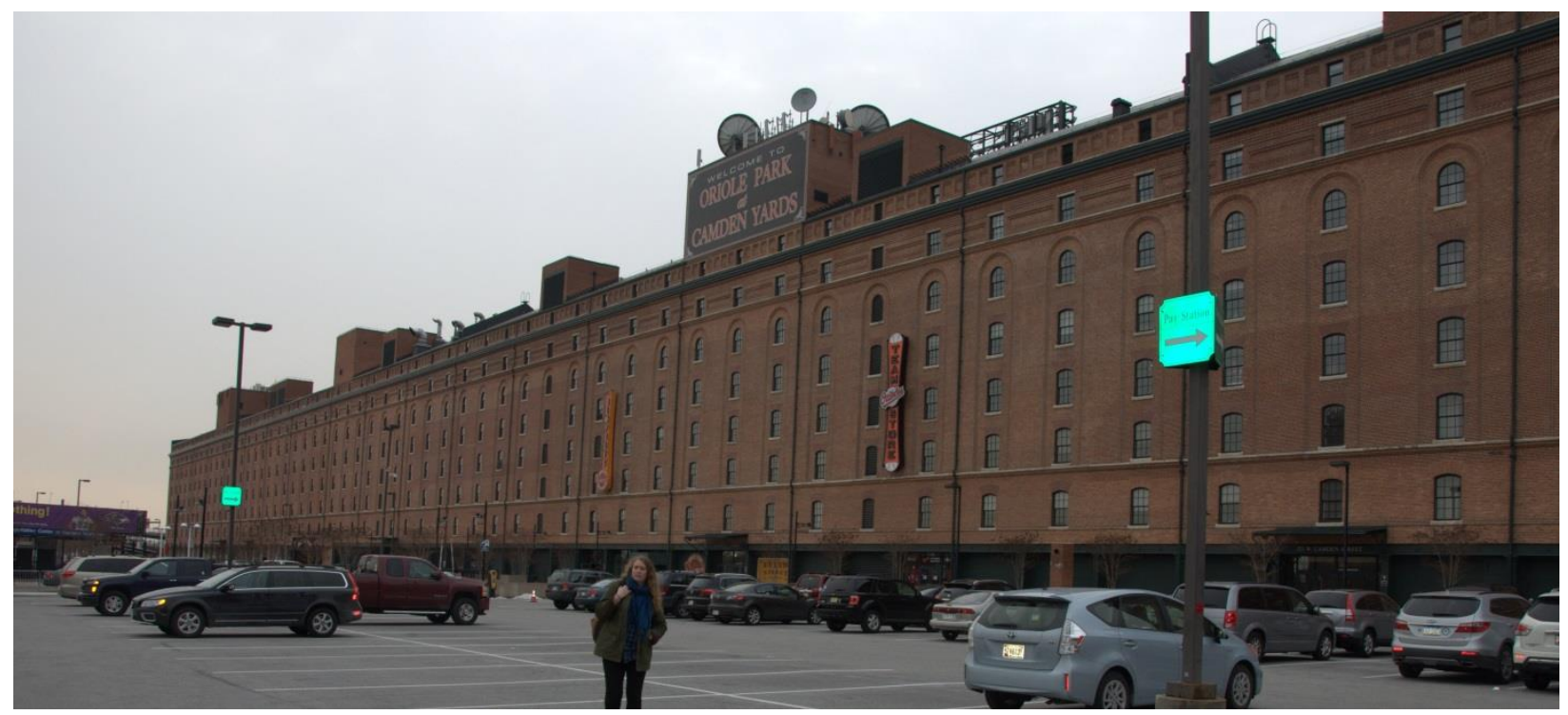

Fig. 1.9 Camden Warehouse front façade, showing vertical recessed arches and horizontal granite stringcourses, which serve to break up the length and height of the exterior. Source: Virginia Harness, February 8, 2014, Baltimore, MD.

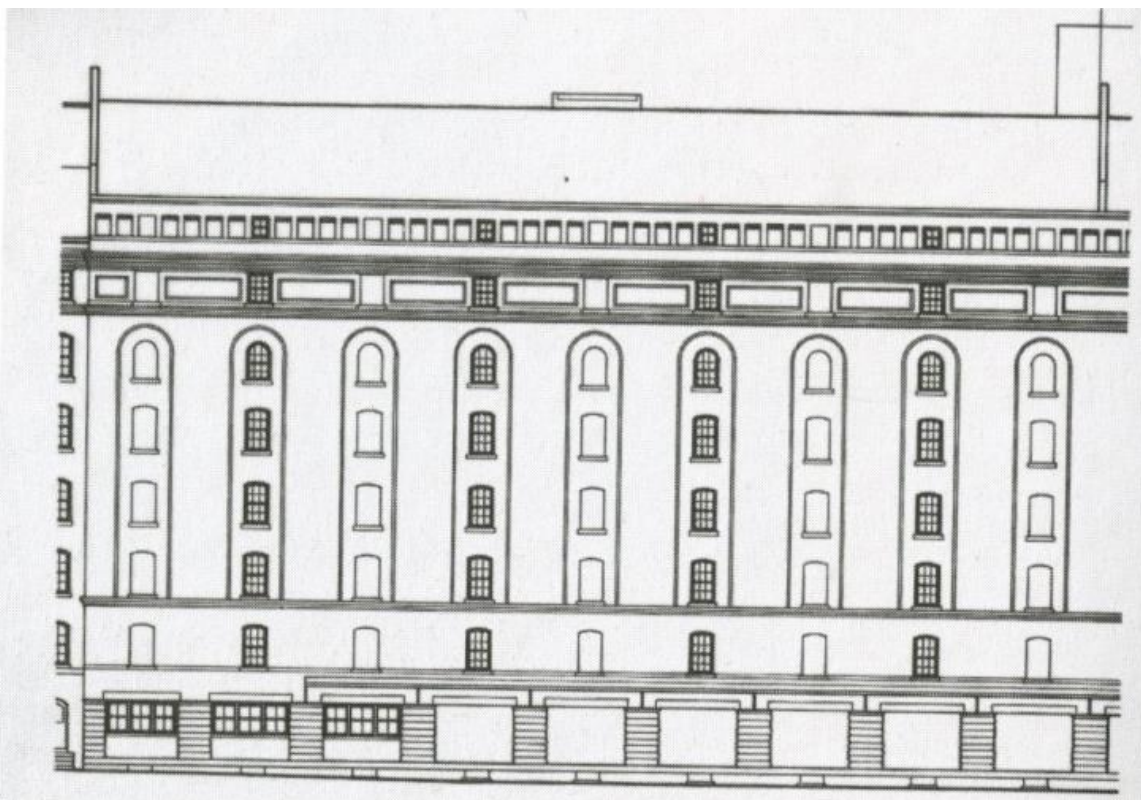

Fig. 1.10 Camden Station, warehouse, partial west elevation. Historic American Buildings Survey, Library of Congress. Source: Hayward, The Architecture of Baltimore, 174. 


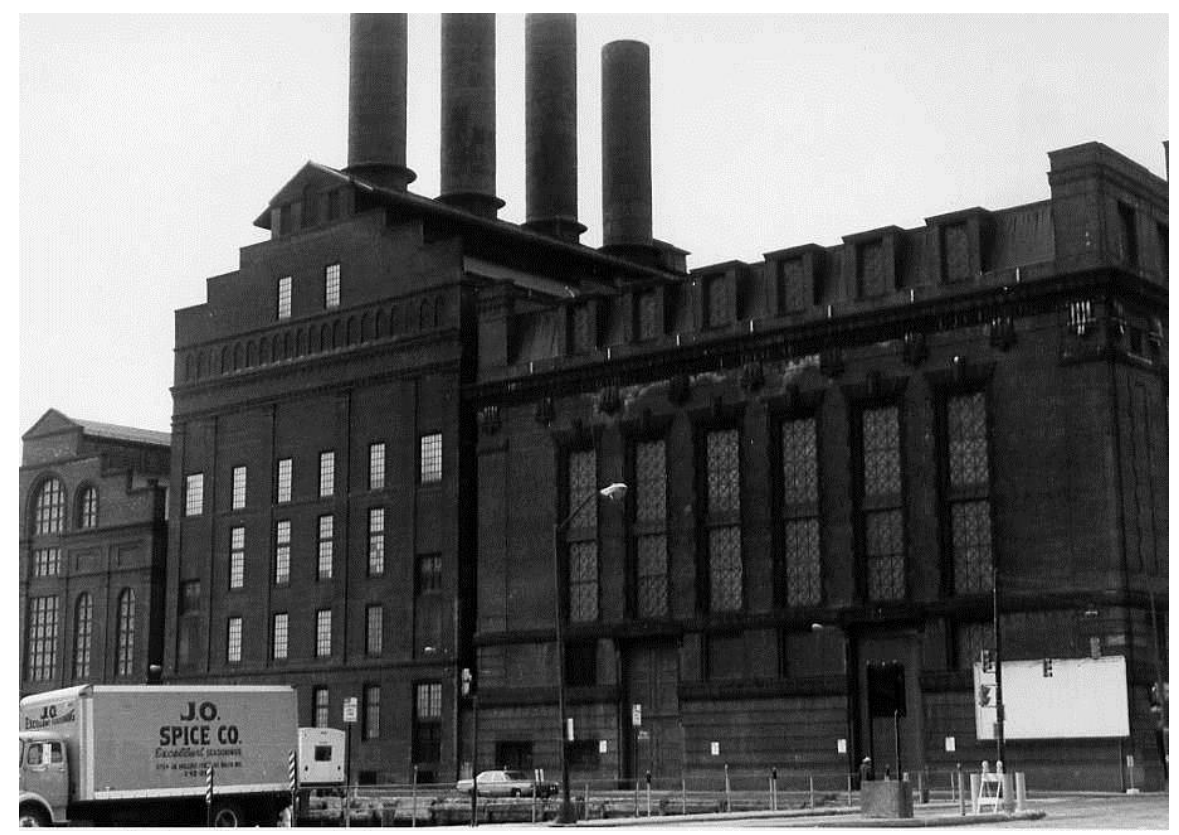

Fig. 1.11 Peter Liebhold."Pratt Street Power Station,” Baltimore City, looking SW from Pratt St. December, 1982. Maryland Historical Trust. Source: National Register of Historic Places, Pratt Street Power Plant, Baltimore, Maryland, National Register \# 87000564.

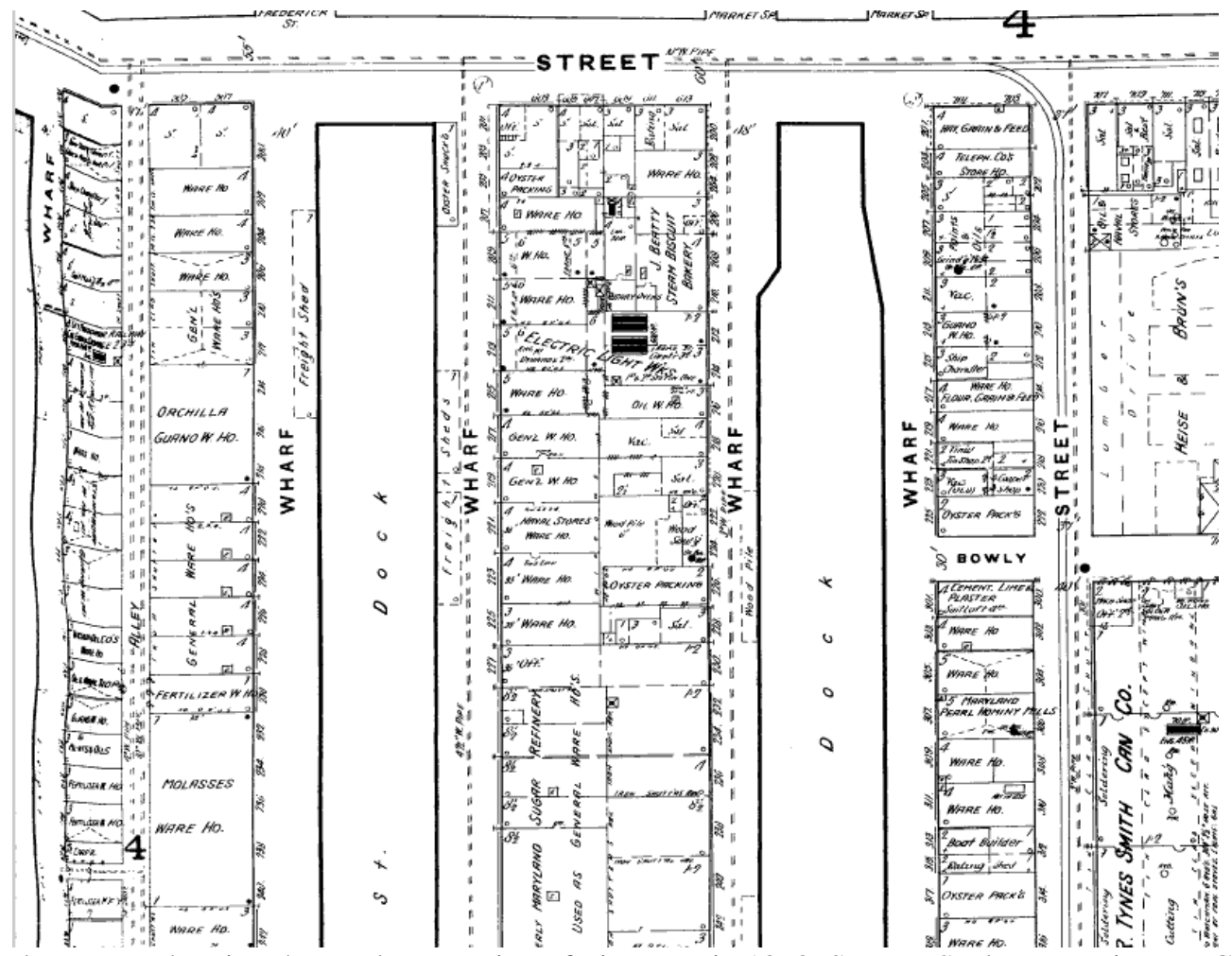

Fig. 1.12 Sanborn map showing the northern portion of Pier Four in 1890. Source: Sanborn-Perris Map Company Limited, Insurance Maps of Baltimore, Maryland Vol. 1, map, 12b. 


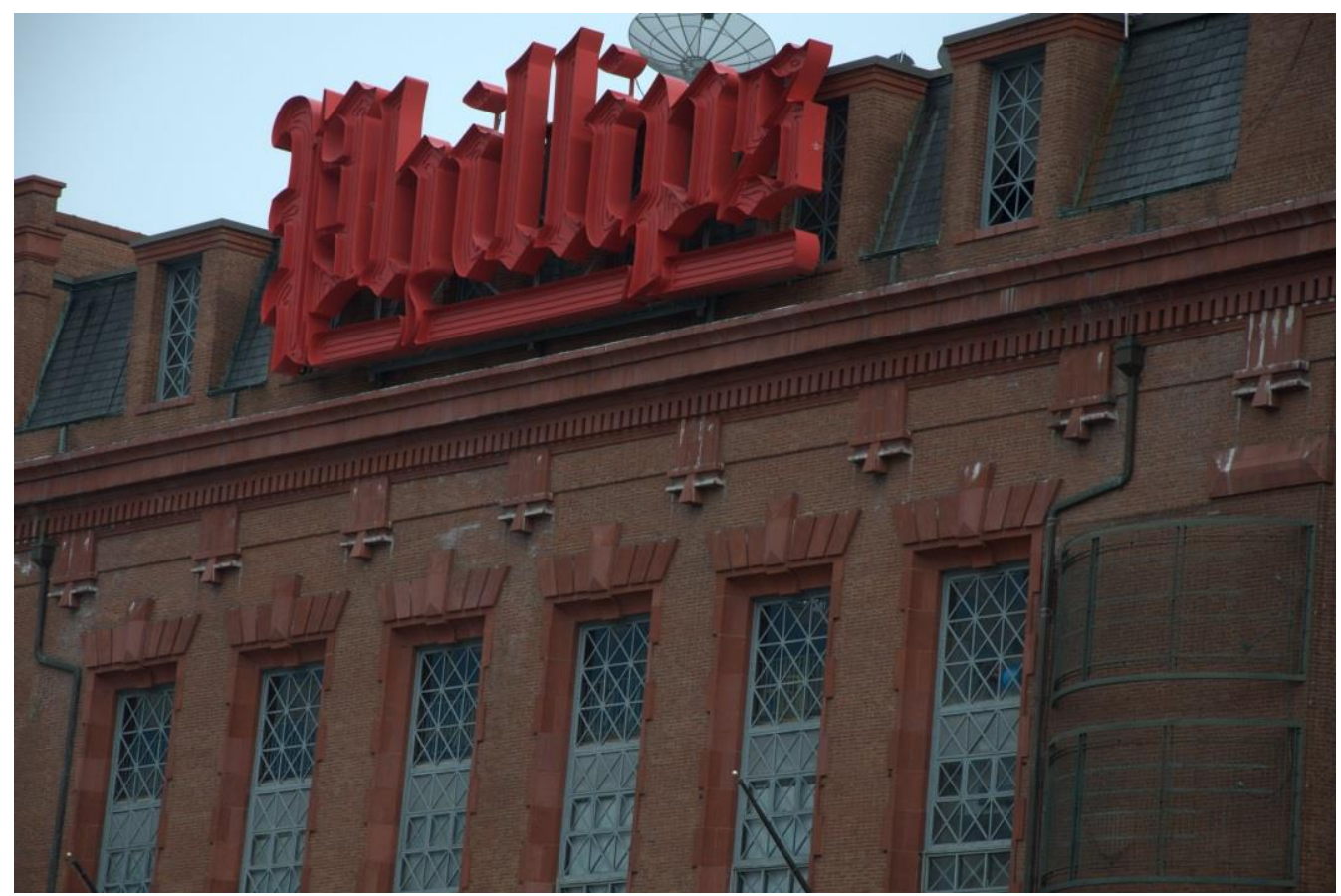

Fig. 1.13 Windows on the northern engine house of the Pratt Street Power Plant showing mansard roof and " $x$ "muntins on windows. Source: Virginia Harness, February 8, 2014, Baltimore, MD.

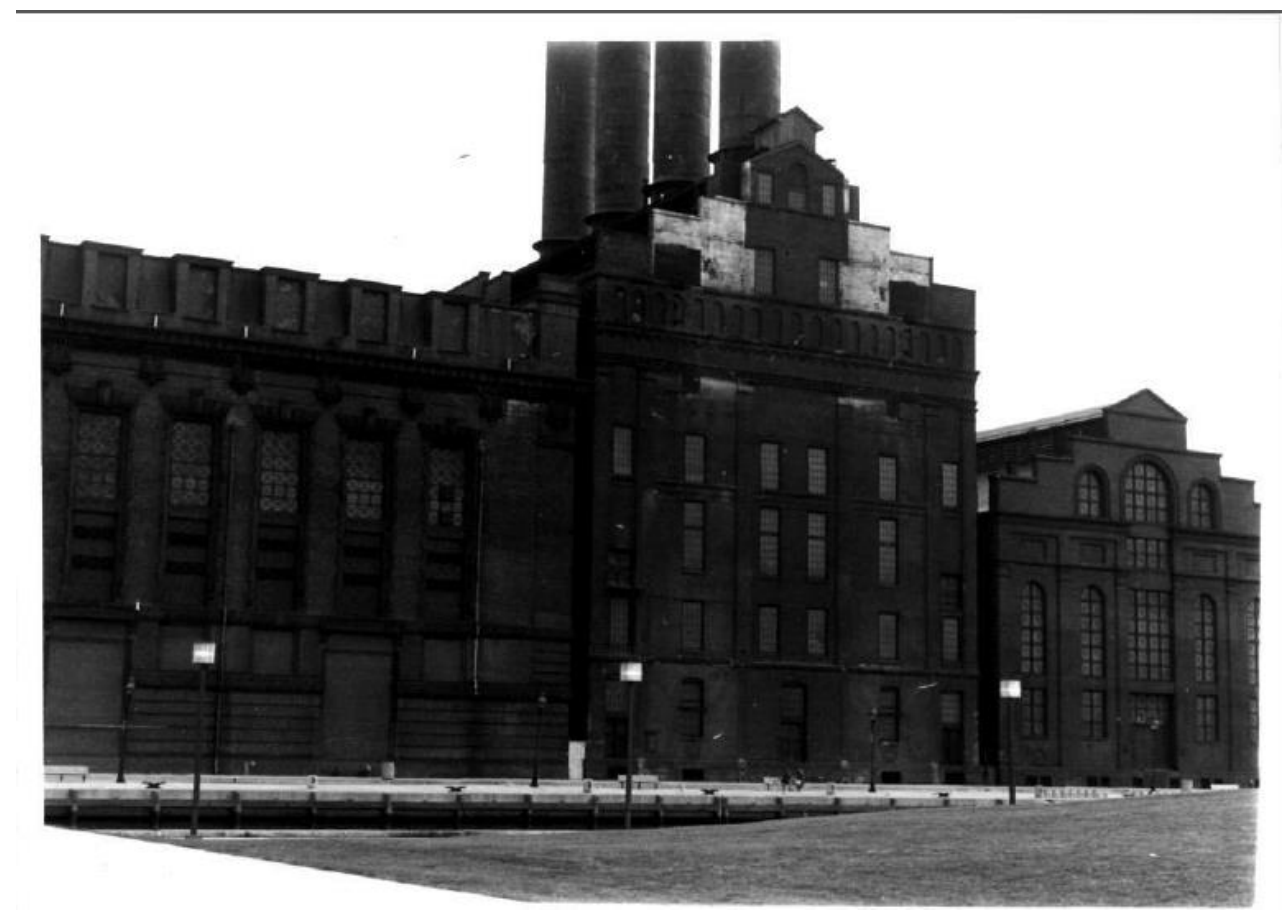

Fig. 1.14 Peter Liebhold."Pratt St. Power Station," Baltimore City, looking SE from Pier 3. December, 1982. Maryland Historical Trust. Source: National Register of Historic Places, Pratt Street Power Plant, Baltimore, Maryland, National Register \# 87000564. 


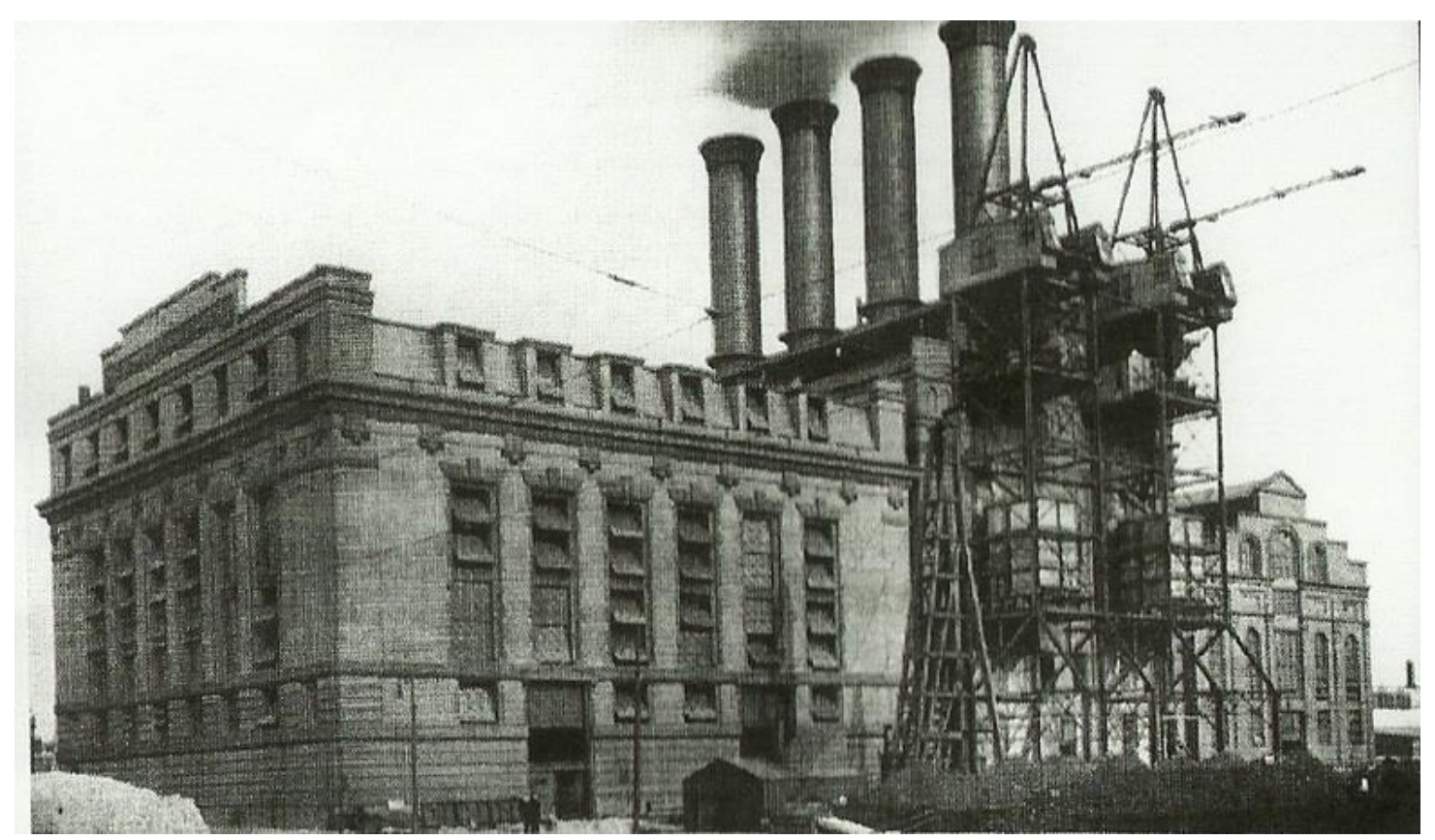

Fig. 1.15 Pratt Street Power Plant, early twentieth century. Source: Hayward, Architecture of Baltimore, 181.

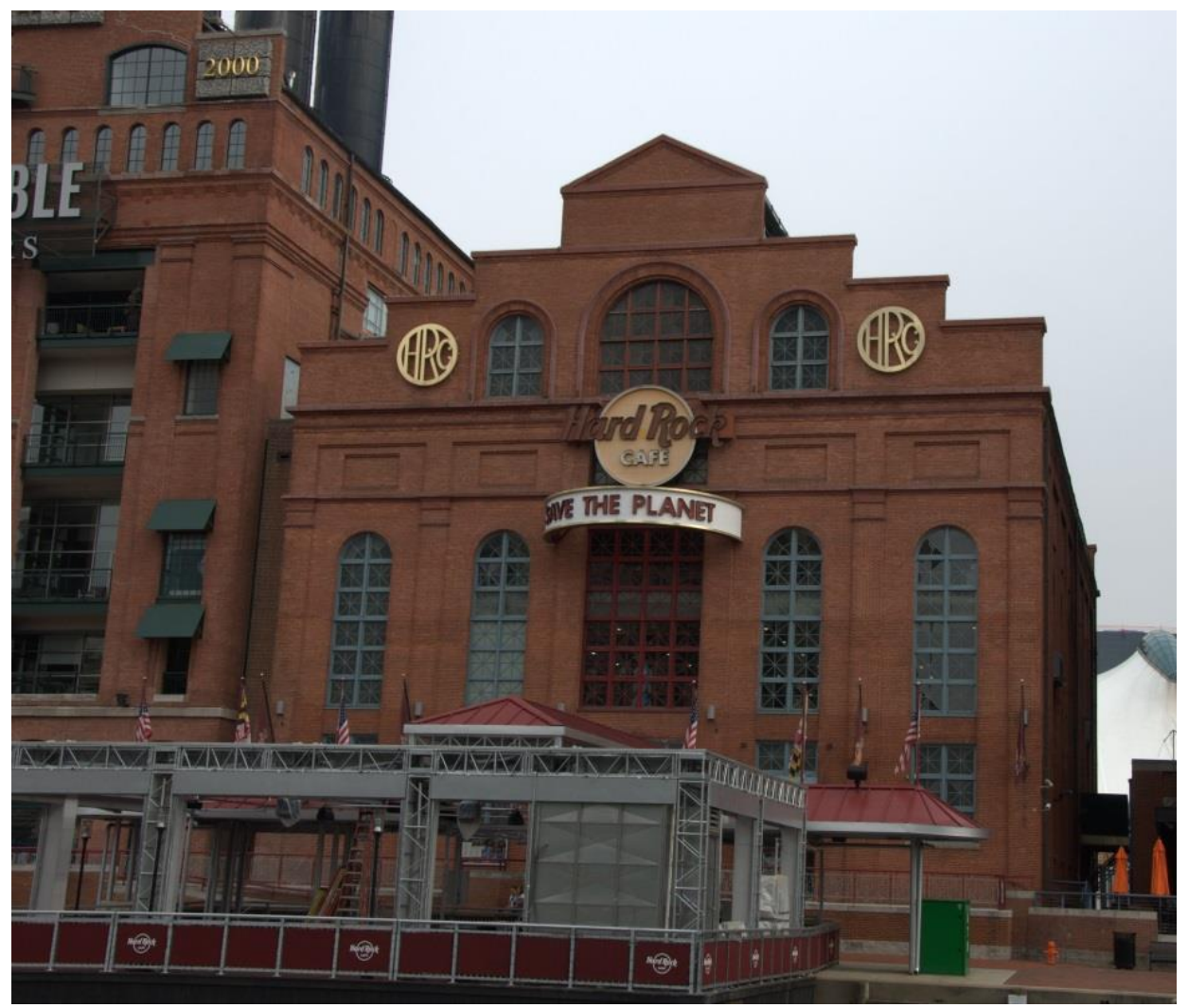

Fig. 1.16 West façade of the south engine house of the Pratt Street Power Plant as seen today. It's original exterior is intact minus the modern Hard Rock Café signage. Source: Virginia Harness, February 8, 2014, Baltimore, MD. 


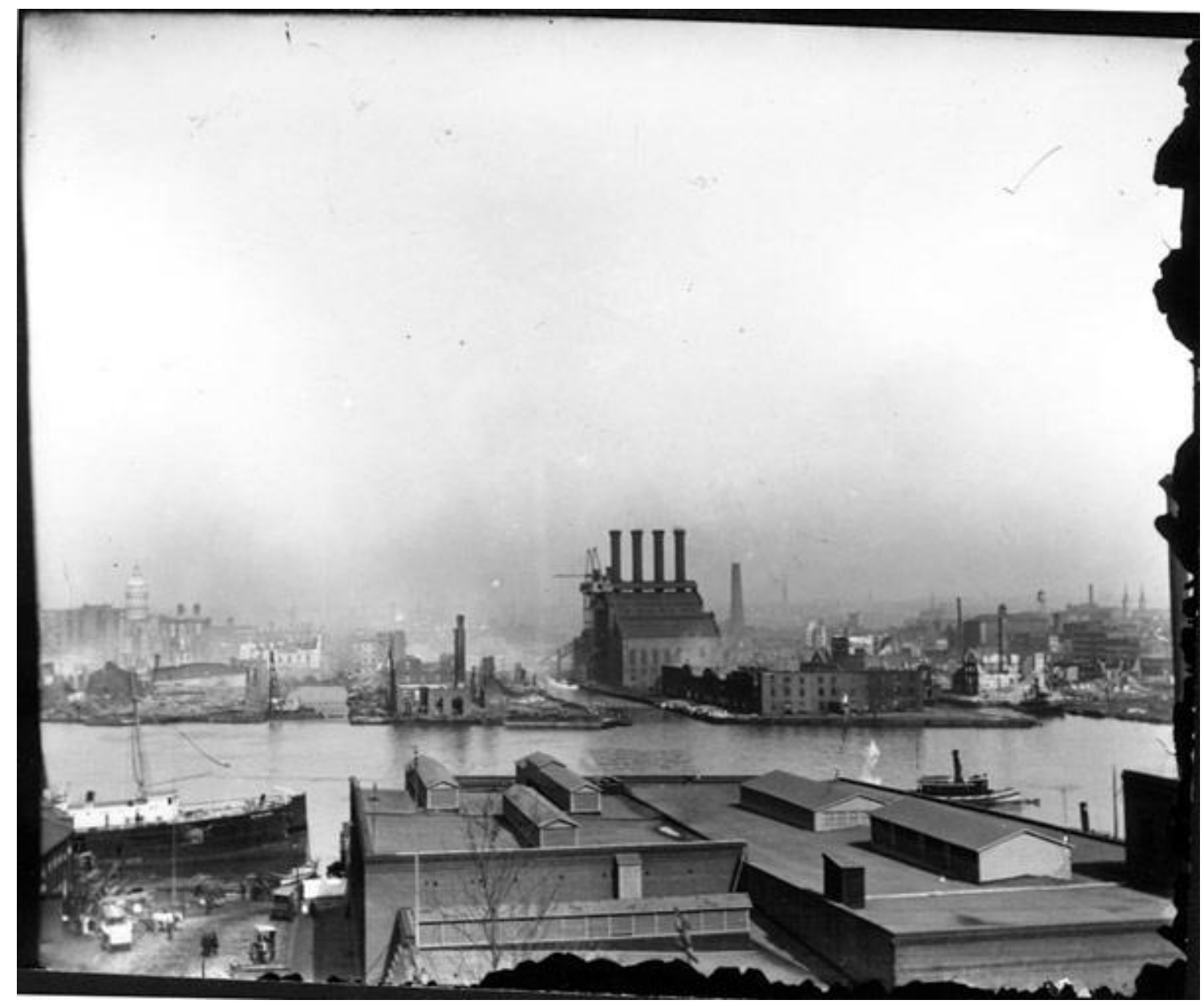

Fig. 1.17 View over the harbor from Federal Hill following the 1904 fire. The Pratt Street Power Plant stands relatively unscathed compared to the surrounding city. Source: "Great Baltimore Fire of 1904." Maryland Digital Cultural Heritage Project, Enoch Pratt Free Library. Last modified 2004. <http://www.mdch.org/fire/\#>

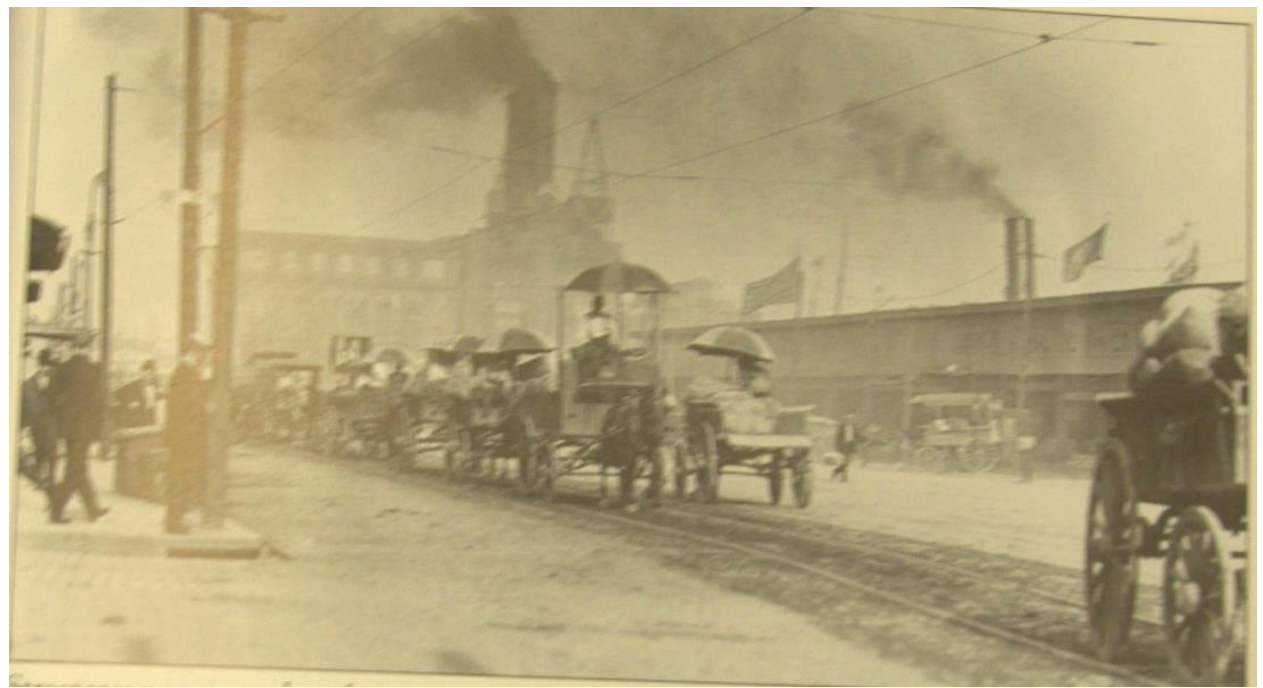

Fig. 1.18 Pratt Street, early 1900s, with a view of the power plant belching smoke in the background. Source: Helton, Baltimore's Streetcars and Buses, 37. 


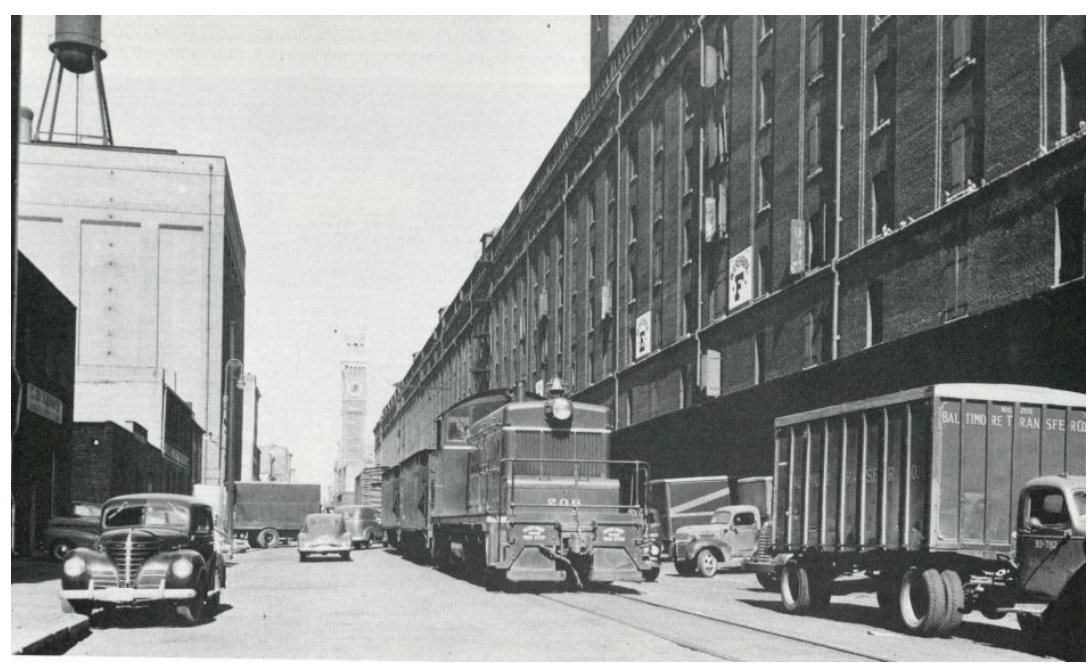

Fig. 2.1 Camden Warehouse c.1949, B\&O Museum Archives. Source: Harwood, Impossible Challenge, 196.

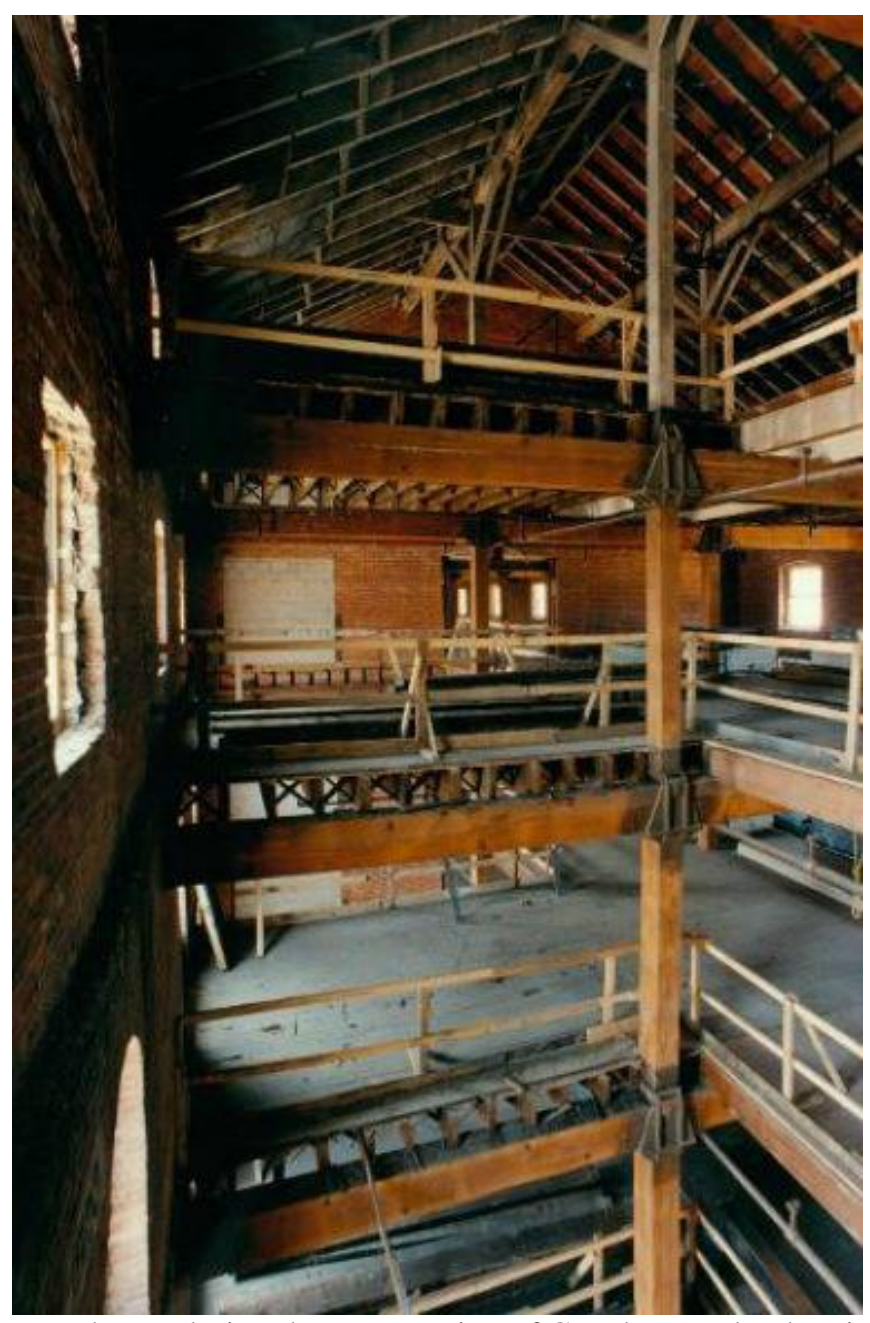

Fig. 2.2 Interior of Camden Warehouse during the construction of Camden Yards, showing the vast storage space inside. Source: "The Construction of Oriole Park at Camden Yards," url:

<http://countingbaseballs.mlblogs.com/2012/03/01/the-construction-of-oriole-park-at-camden-yards/> 


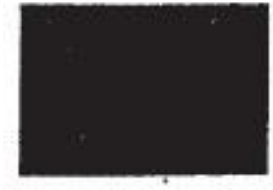

HILL ST.

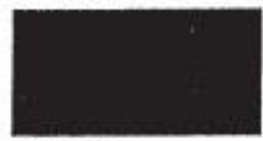

LEE ST.

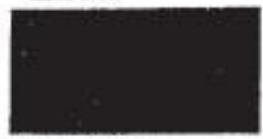

BARRE ST.

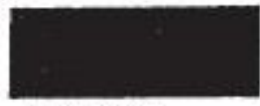

CONWAYST.
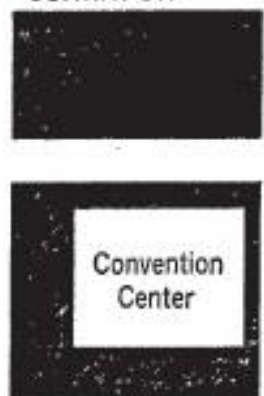

Federal Courthouse

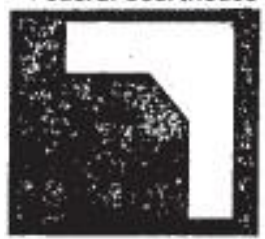

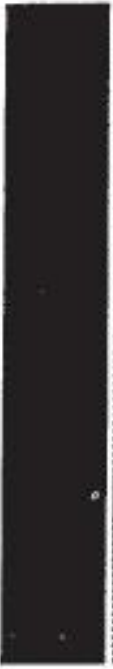
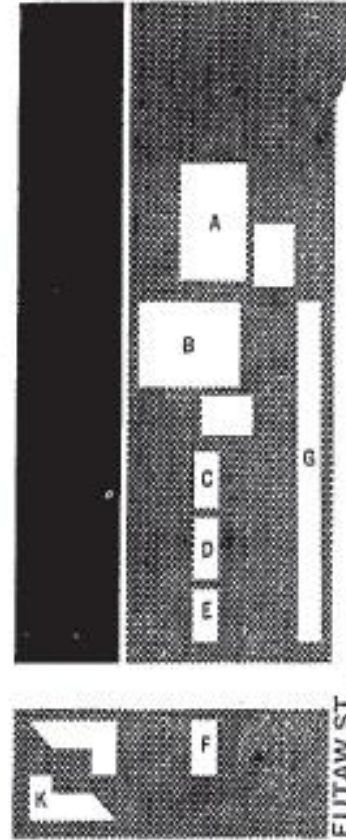

CAMDEN ST.

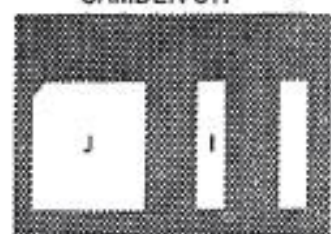

PRATT ST.

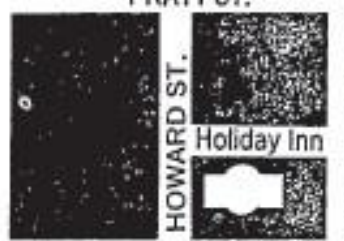

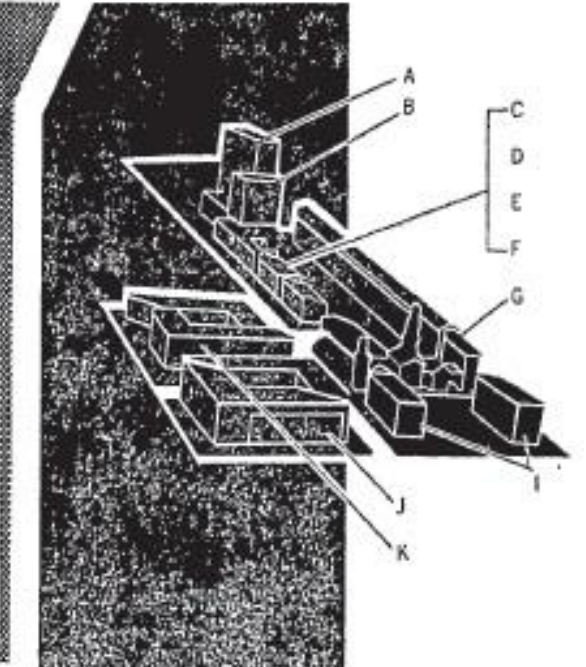
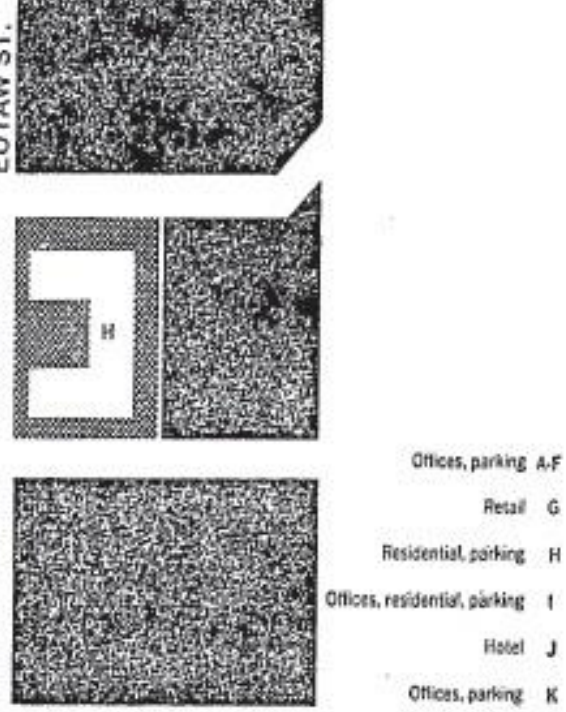

Sel srabhic-Nark Watoes

Fig. 2.3 Carr's plan for Camden Yards. Source: C. Fraser Smith, “Plan would make bleak Camden yards a \$170 million living-working complex," The Baltimore Sun, May 23, 1979, A1. 


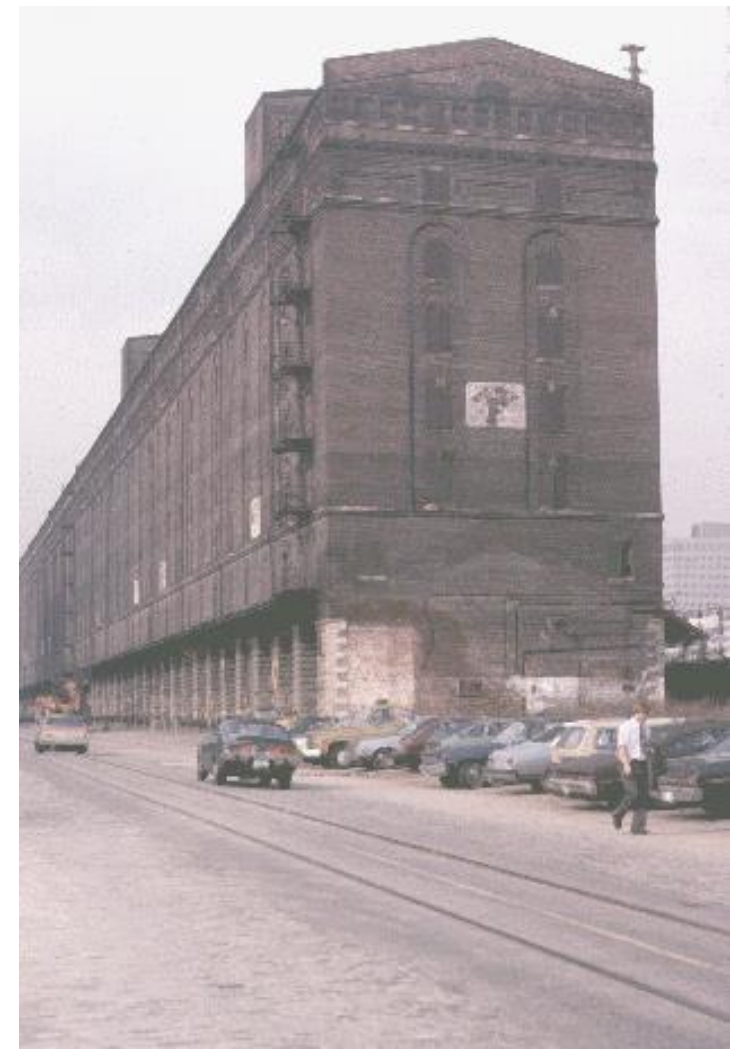

Fig. 2.4 The warehouse in 1978, looking rundown and dirty. Source: "Mike's Railroad Page," <http://www.navpooh.com/camyards.html>

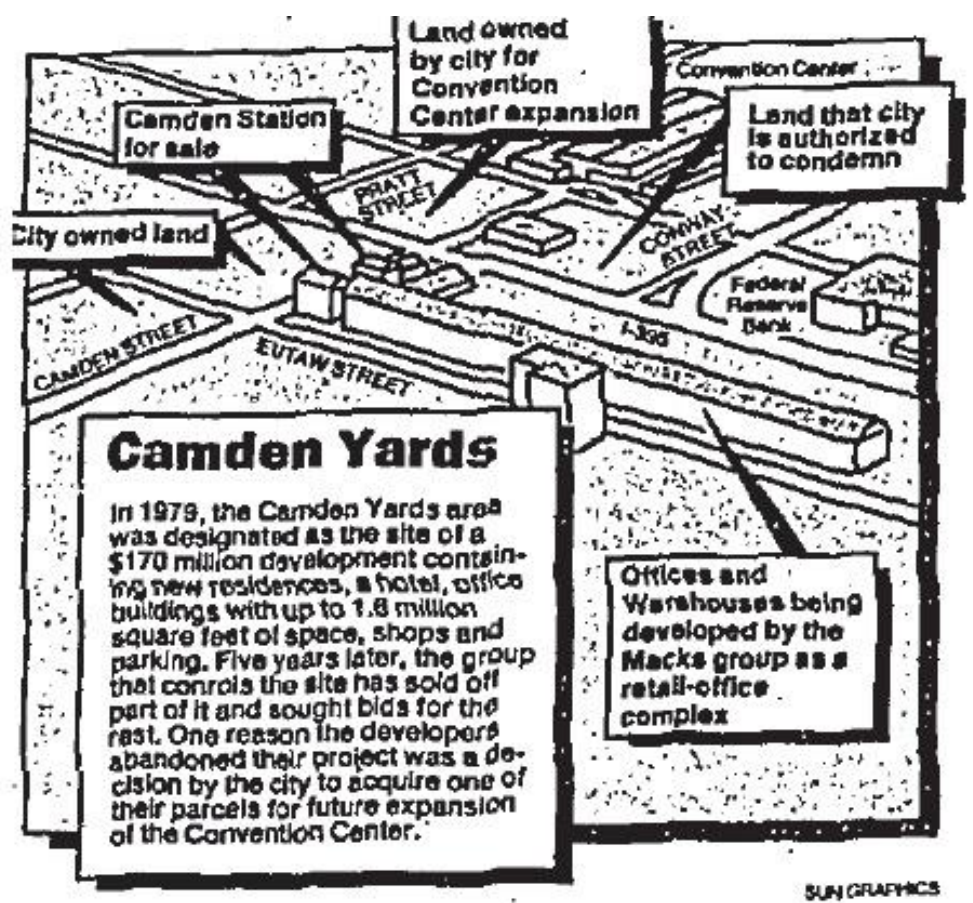

Fig. 2.5 "Harbor Exchange" planned by developer Morton Macks. Source: Sandy Banisky, "Camden complex planned: Zoning requested for stores, offices in old warehouse," The Baltimore Sun, September 29, 1983, E1. 


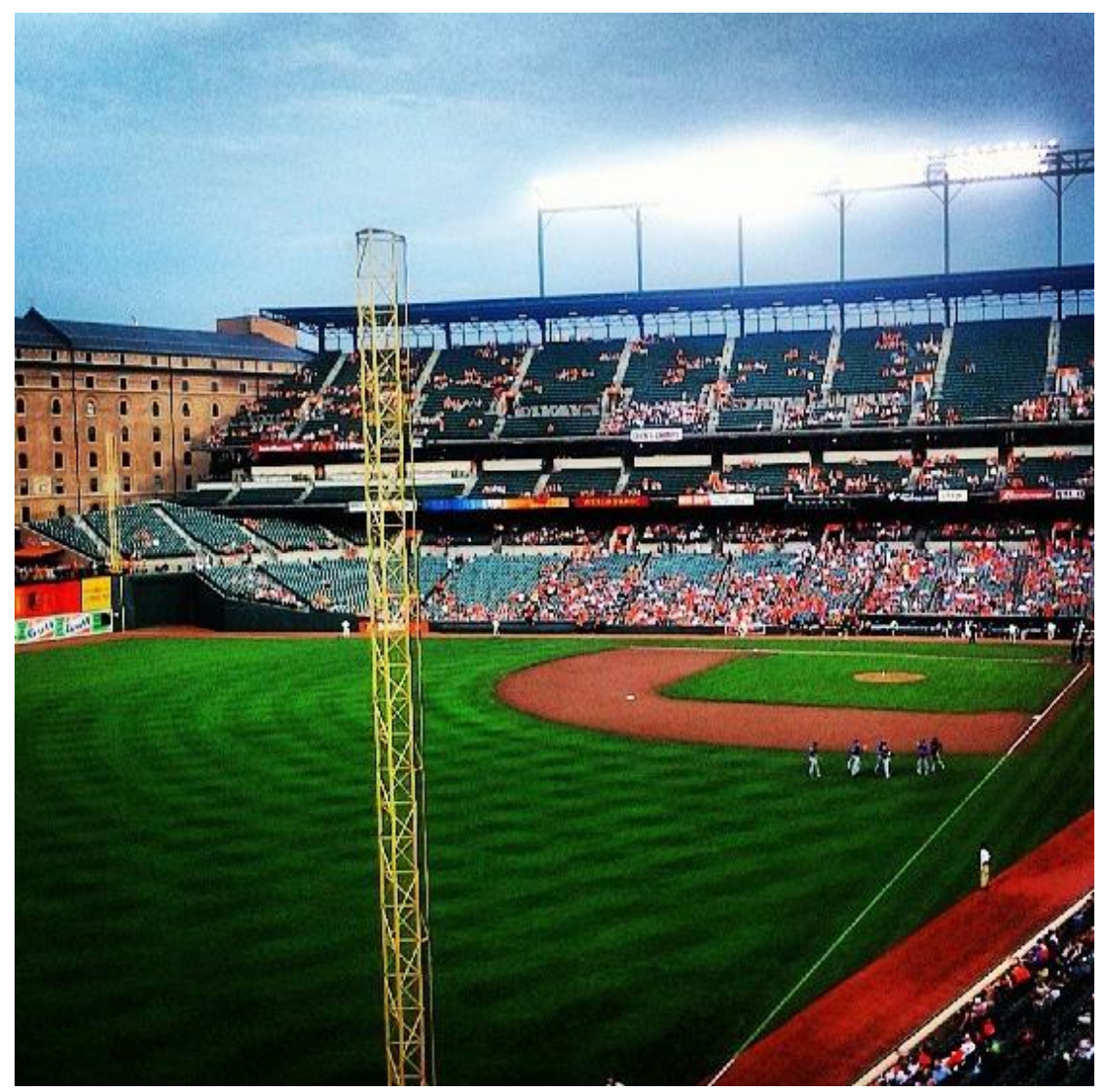

Fig. 2.6 Photograph showing the incorporation of the warehouse into the fabric of the stadium. Source: Virginia Harness, July 10, 2013, Baltimore, MD.

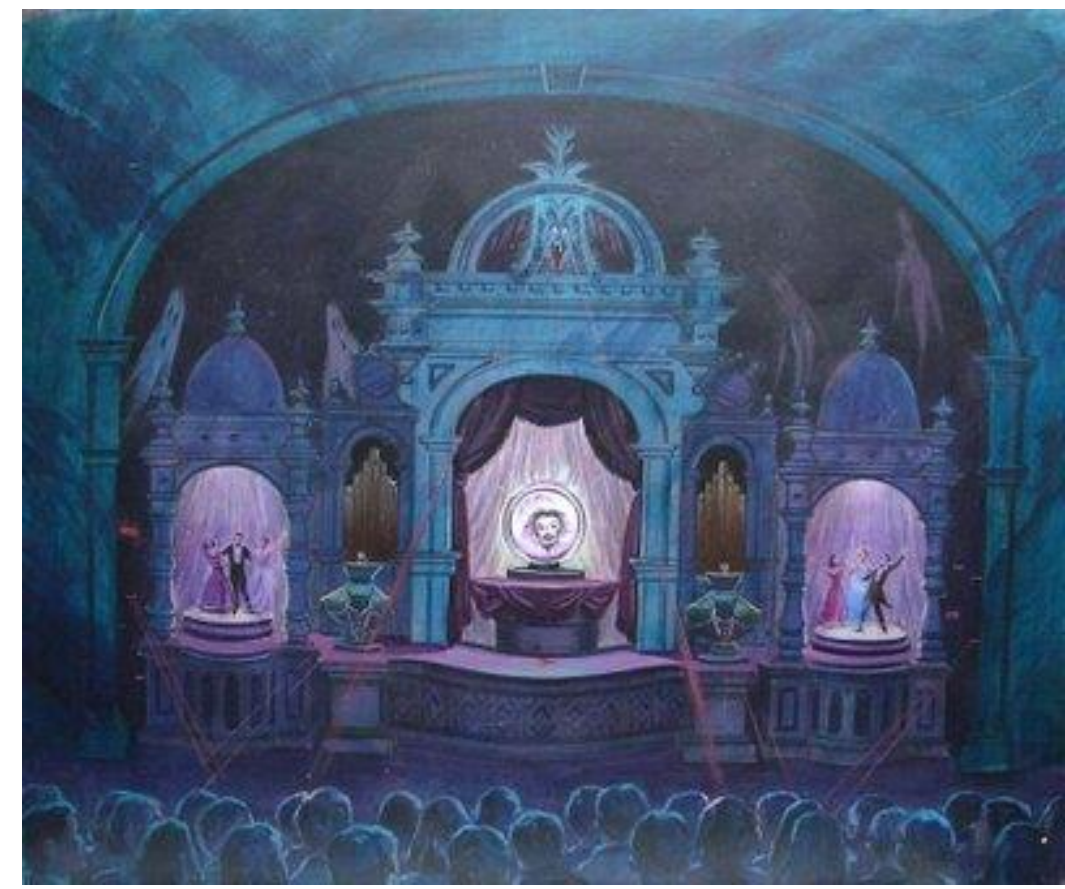

Fig. 2.7 Concept art for Six Flags urban theme park in the power plant by The Goddard Group. Source: "Baltimore Power Plant," The Goddard Group, url: <http://www.garygoddard.com/entertainment-design/baltimore-powerplant/> 


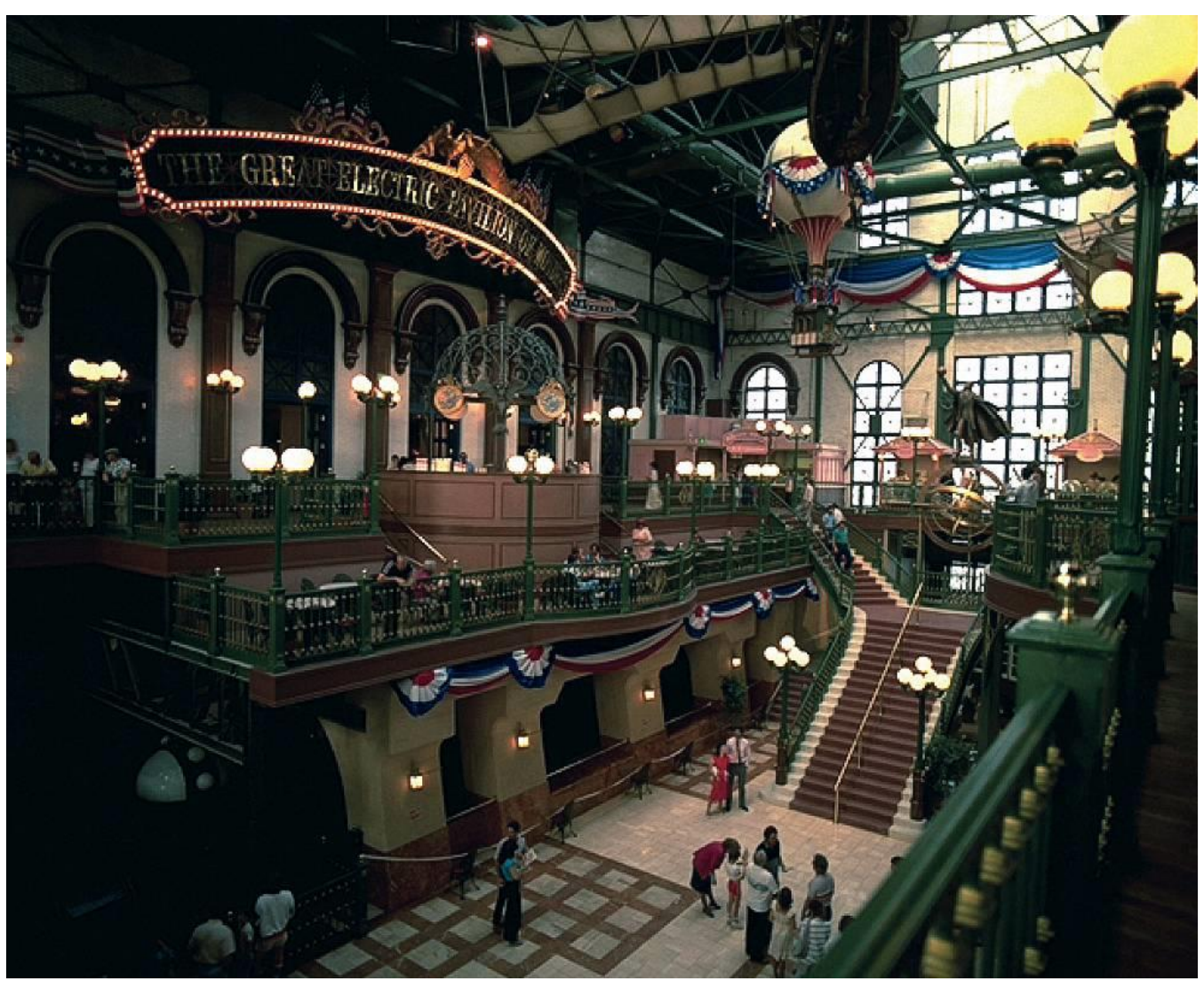

Fig 2.8 Interior lobby space of the Six Flags Power Plant in the 1980s. Source: "Baltimore Power Plant," The Goddard Group, url: <http://www.garygoddard.com/entertainment-design/baltimore-power-plant/>

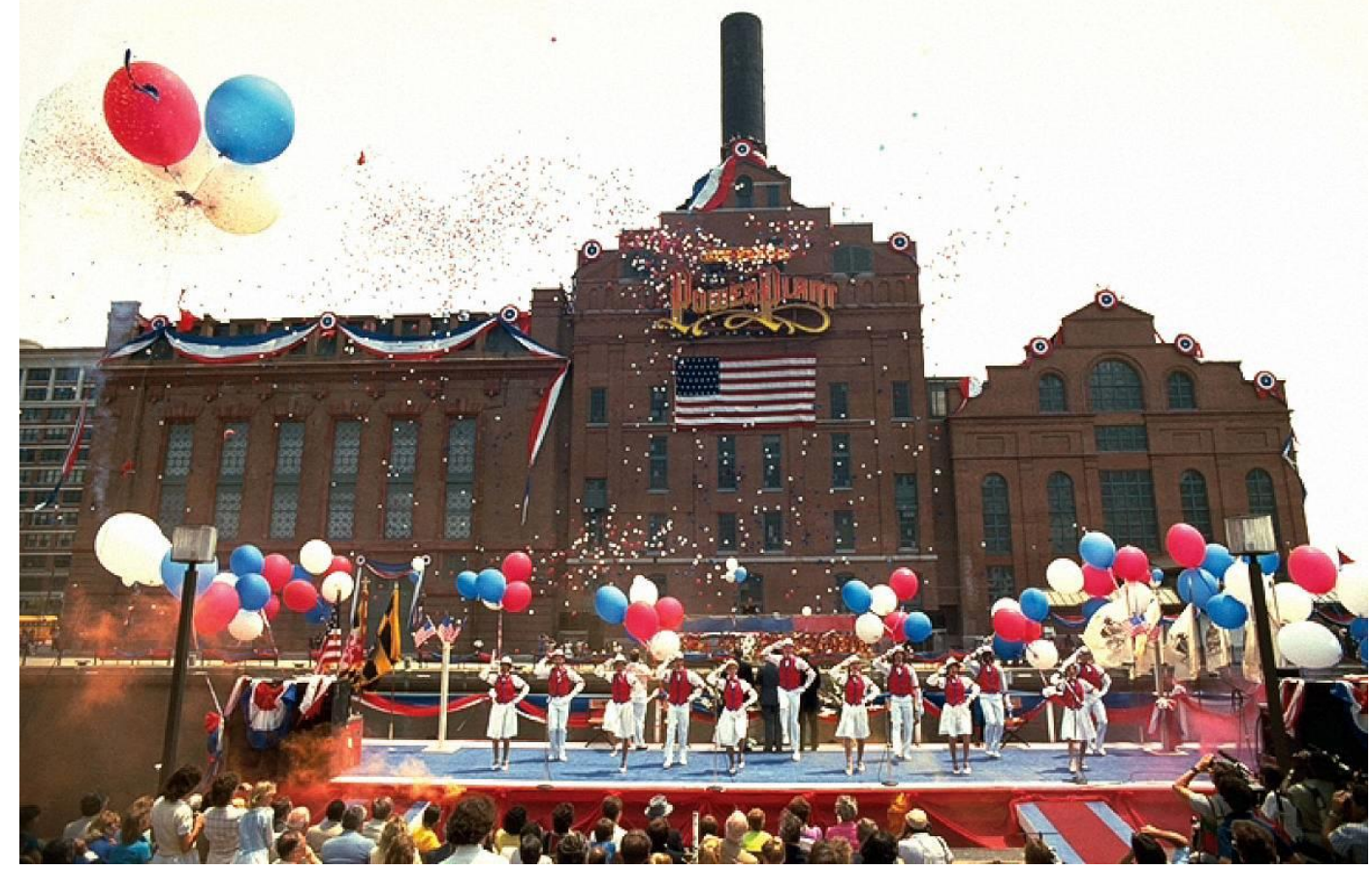

Fig. 2.9 Exterior of the Six Flags version of the Power Plant. Source: "Baltimore Power Plant," The Goddard Group, url: <http://www.garygoddard.com/entertainment-design/baltimore-power-plant/> 


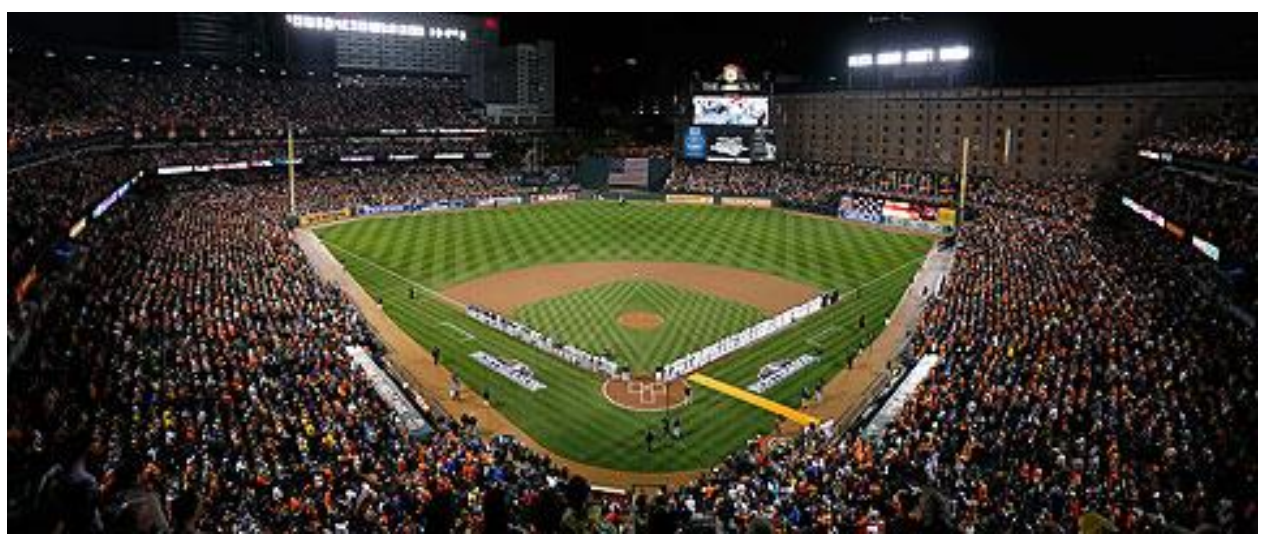

Fig. 2.10 Panoramic view of a packed Oriole Park at Camden Yards. The Camden Warehouse looms large of right field in the background. Source: "Oriole Park at Camden Yards," url: http://baltimore.orioles.mlb.com/bal/ballpark/

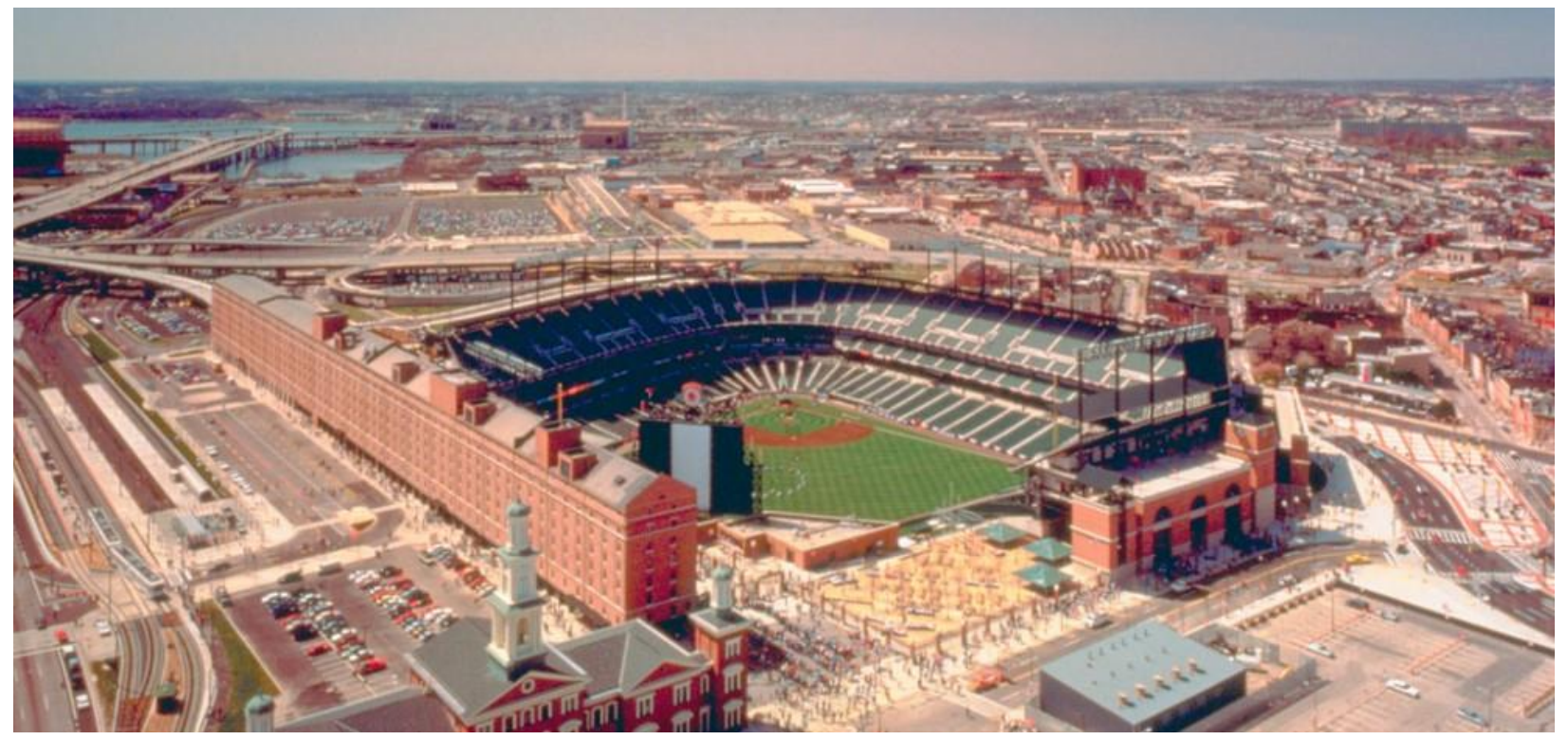

Fig. 2.11 Aerial view of Oriole Park at Camden Yards designed by HOK (now Populous), showing red brick and arches of the new construction at right that mimic the architecture of the historic warehouse (left). Source:

“Transforming Ballpark Design: Oriole Park at Camden Yards," url: <http://populous.com/project/oriole-park-atcamden-yards/> 


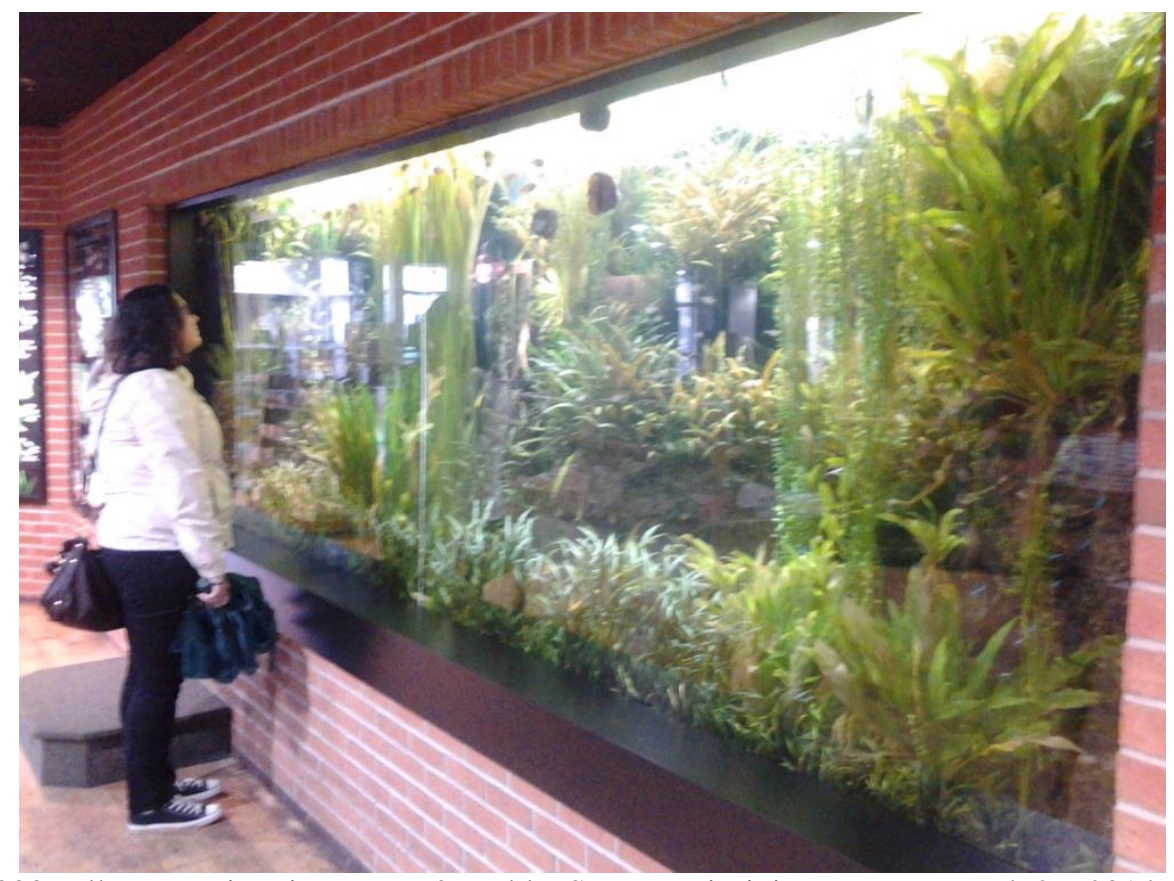

Fig 2.12 The 3,000 gallon aquarium in Barnes \& Noble. Source: Virginia Harness, March 29, 2014, Baltimore, MD.

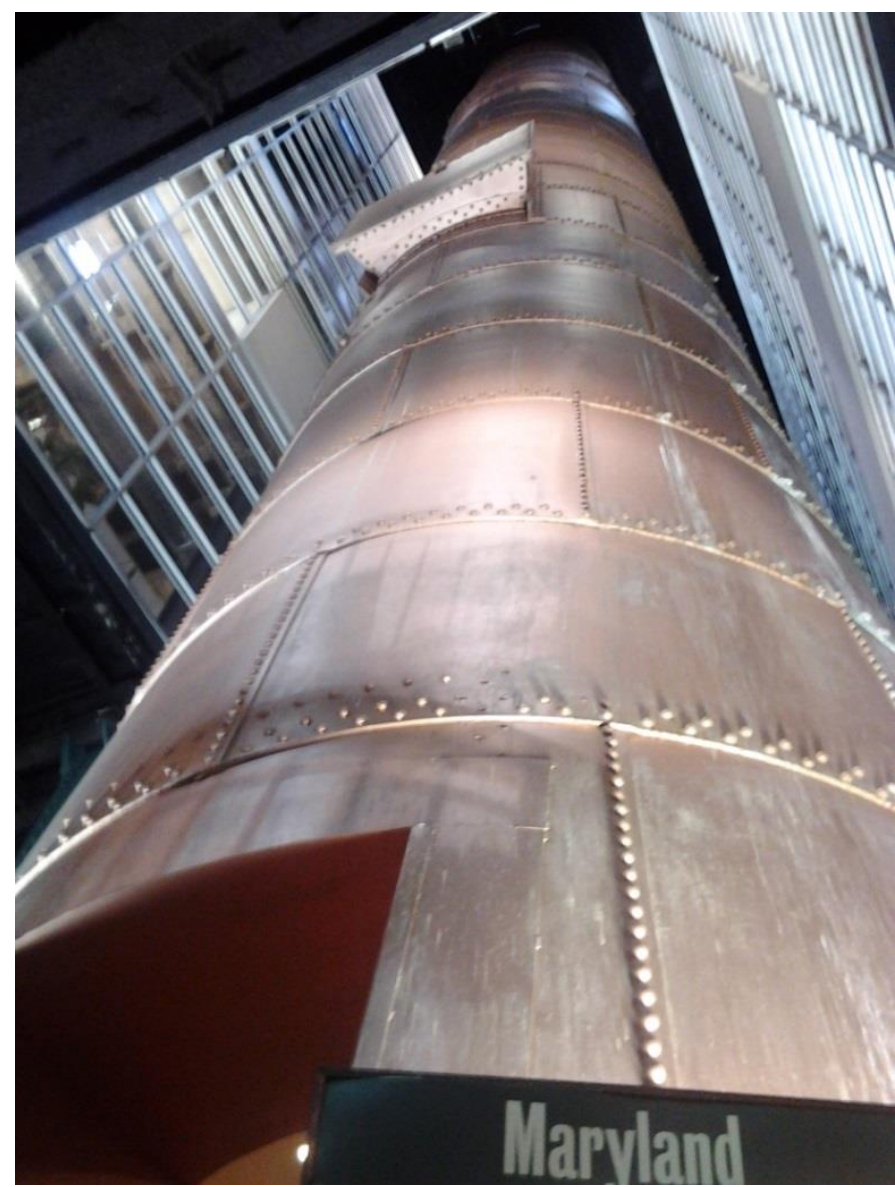

Fig. 2.13 A smokestack rises up through the levels of the Barnes \& Noble Bookstore in the central boiler house of the Pratt Street Power Plant. Source: Virginia Harness, March 29, 2014, Baltimore, MD. 


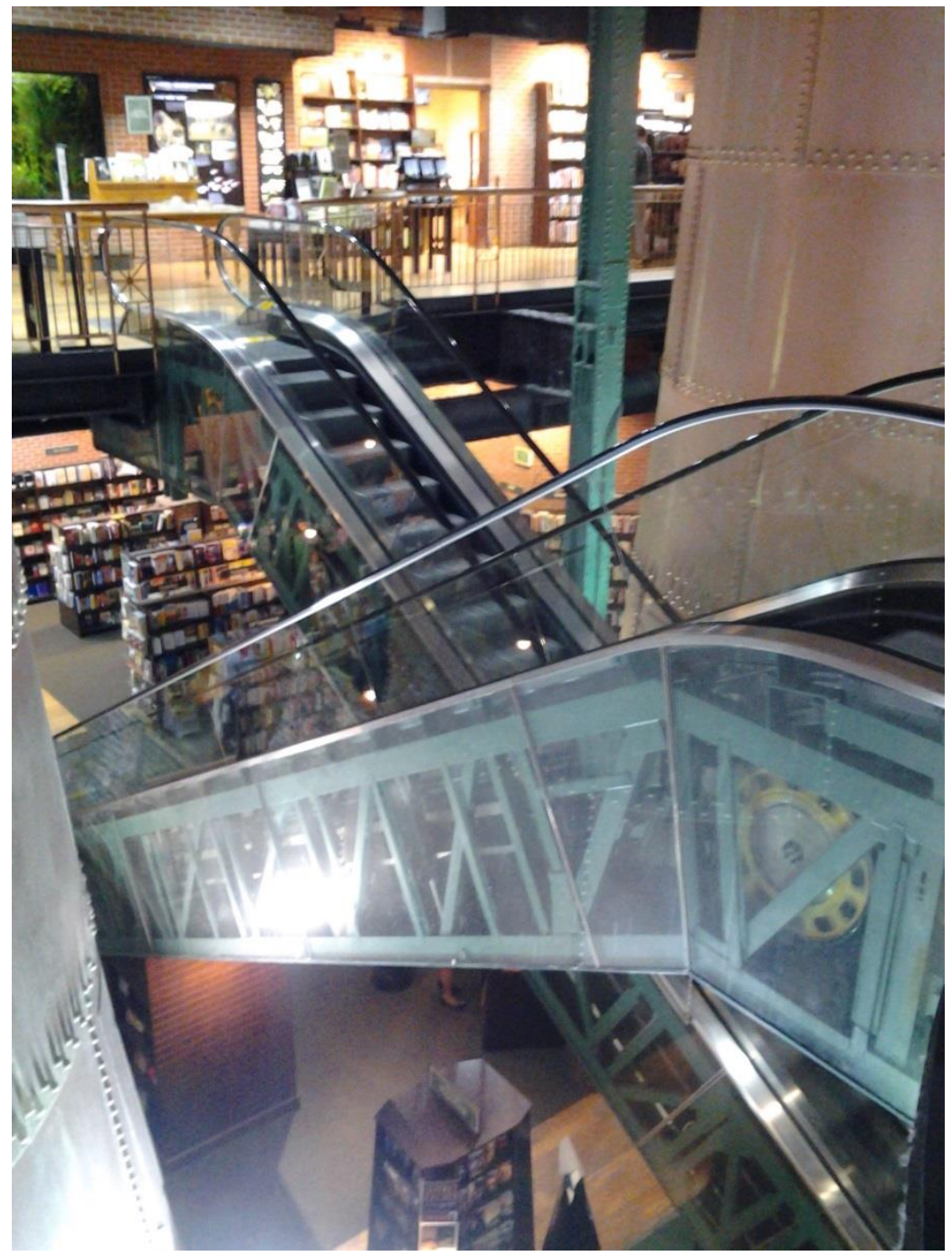

Fig 2.14 The interior workings of the escalator are exposed to shoppers at the Barnes \& Noble Bookstore, adding to the industrial feeling of the space. Source: Virginia Harness, March 29, 2014, Baltimore, MD. 


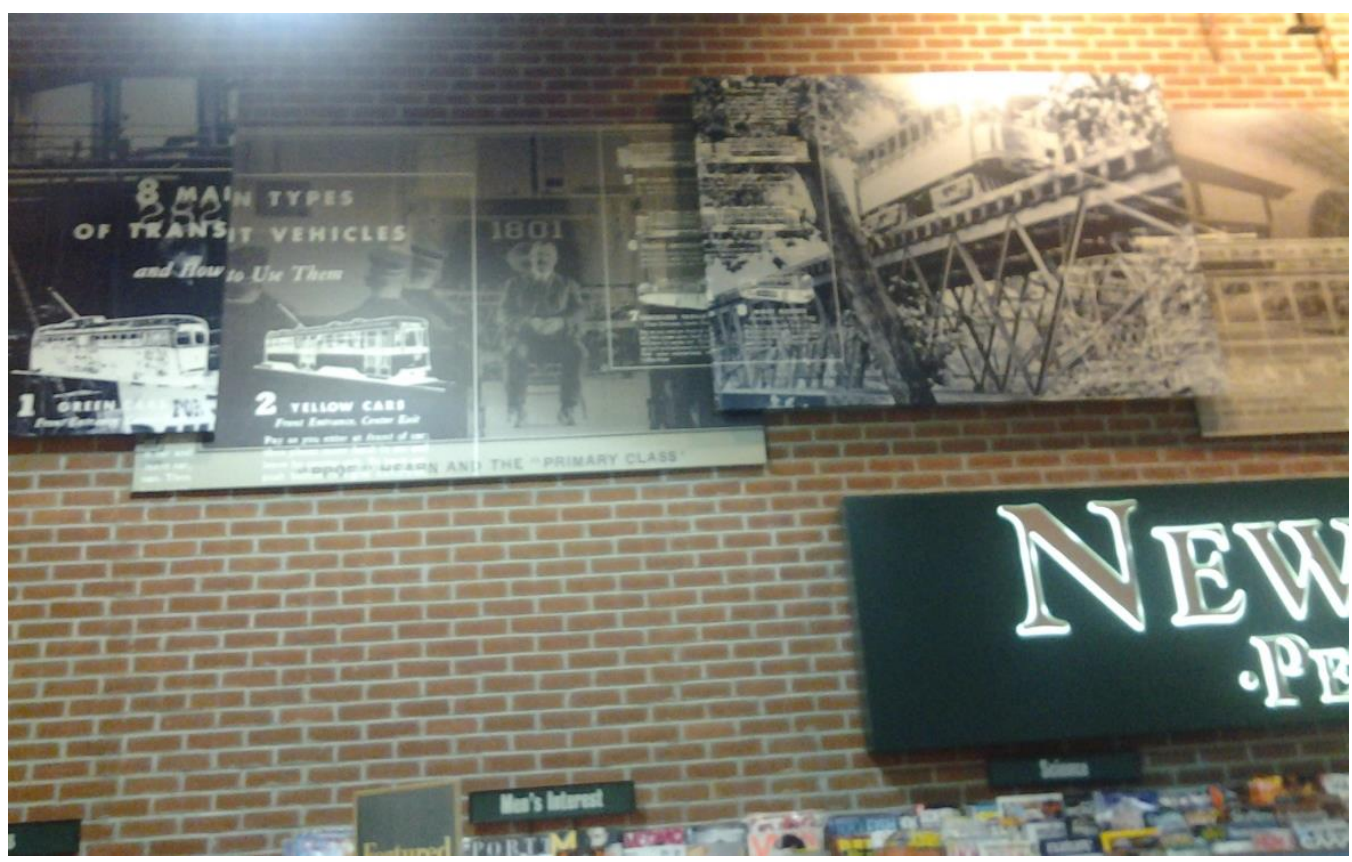

Fig. 3.1 A portion of the historic display above the magazine section in Barnes \& Noble in the Pratt Street Power Plant. Source: Virginia Harness, March 29, 2014, Baltimore, MD.

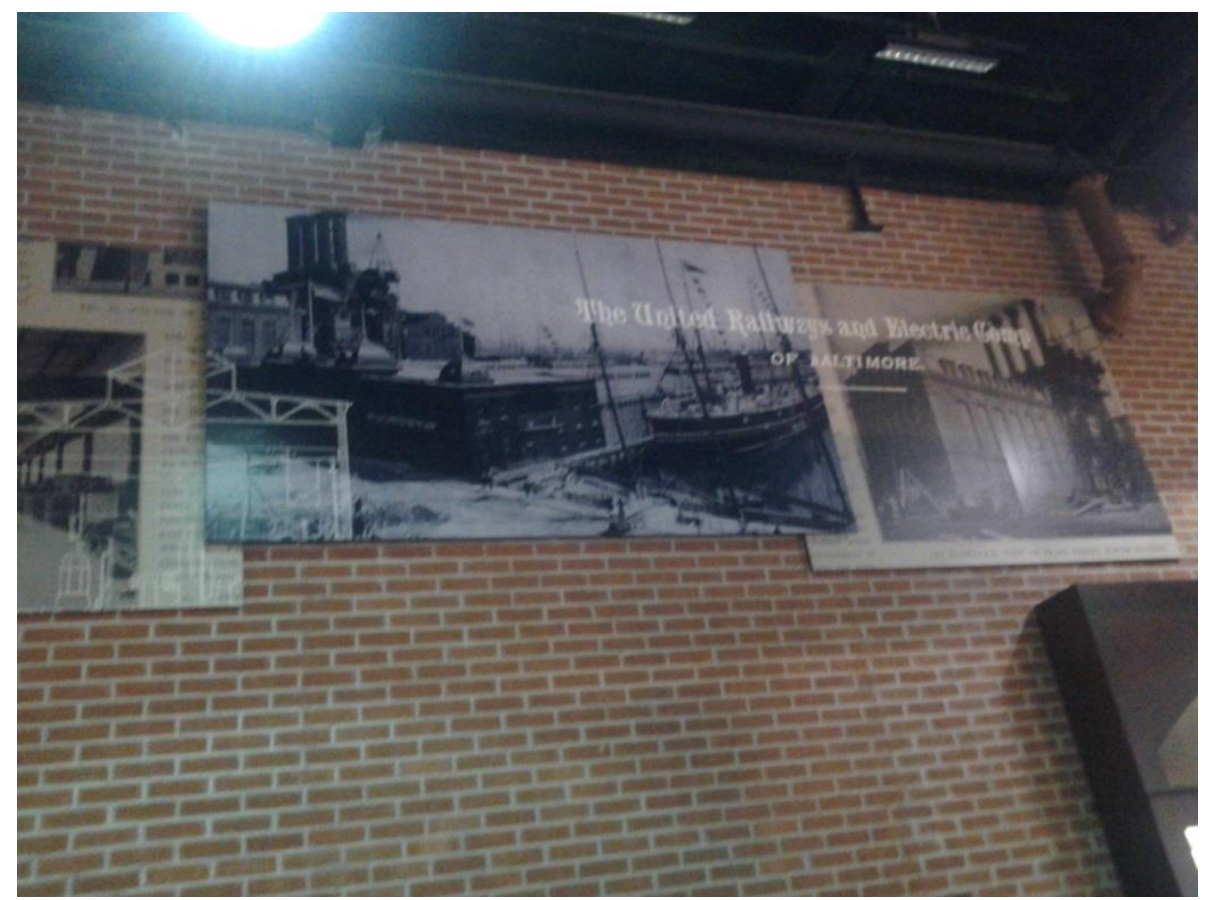

Fig. 3.2 Continuation of the display in Barnes \& Noble, showing a historic photo and text that reads "The United Railway and Electric Company of Baltimore.” Source: Virginia Harness, March 29, 2014, Baltimore, MD. 


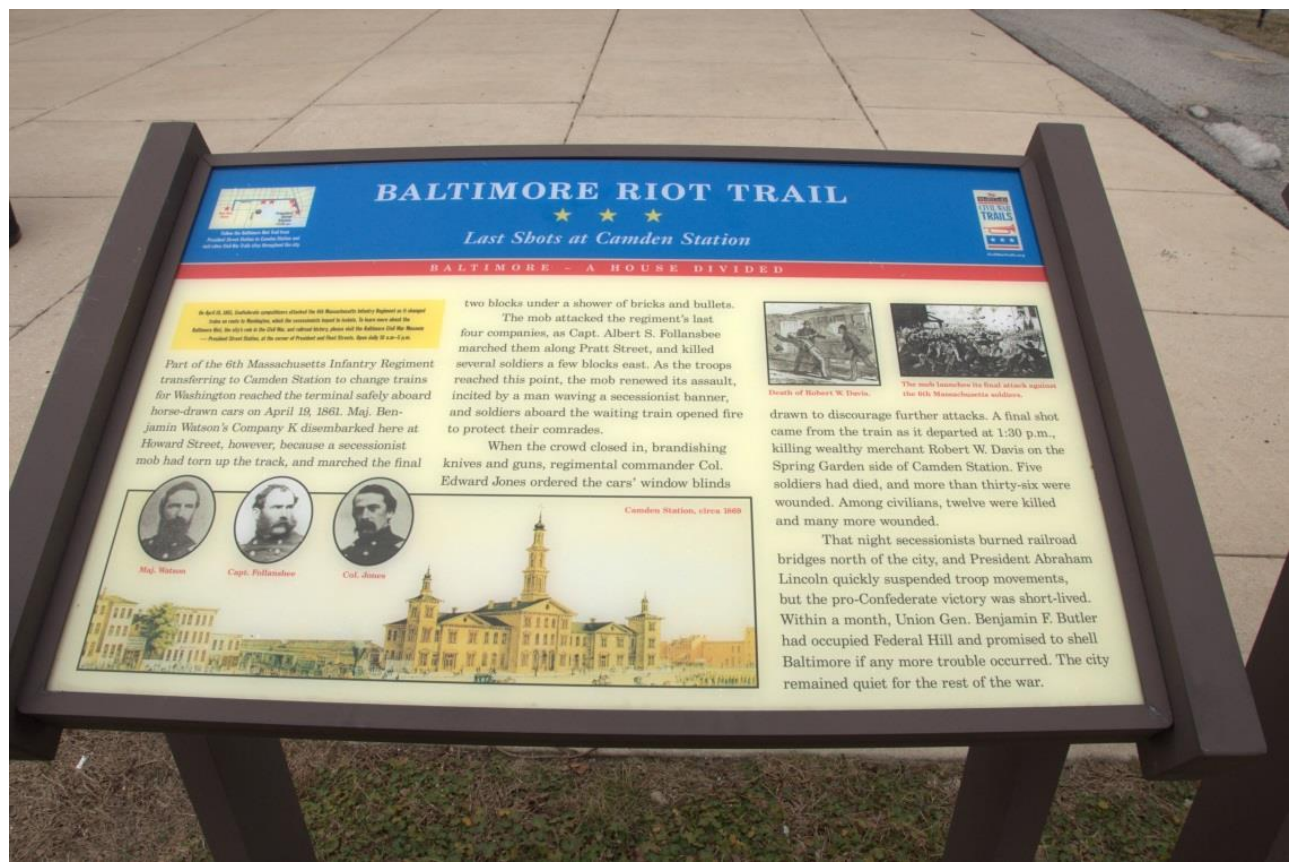

Fig. 3.3 Civil War Trails marker next to Camden Station. Source: Virginia Harness, February 8, 2014, Baltimore, MD.

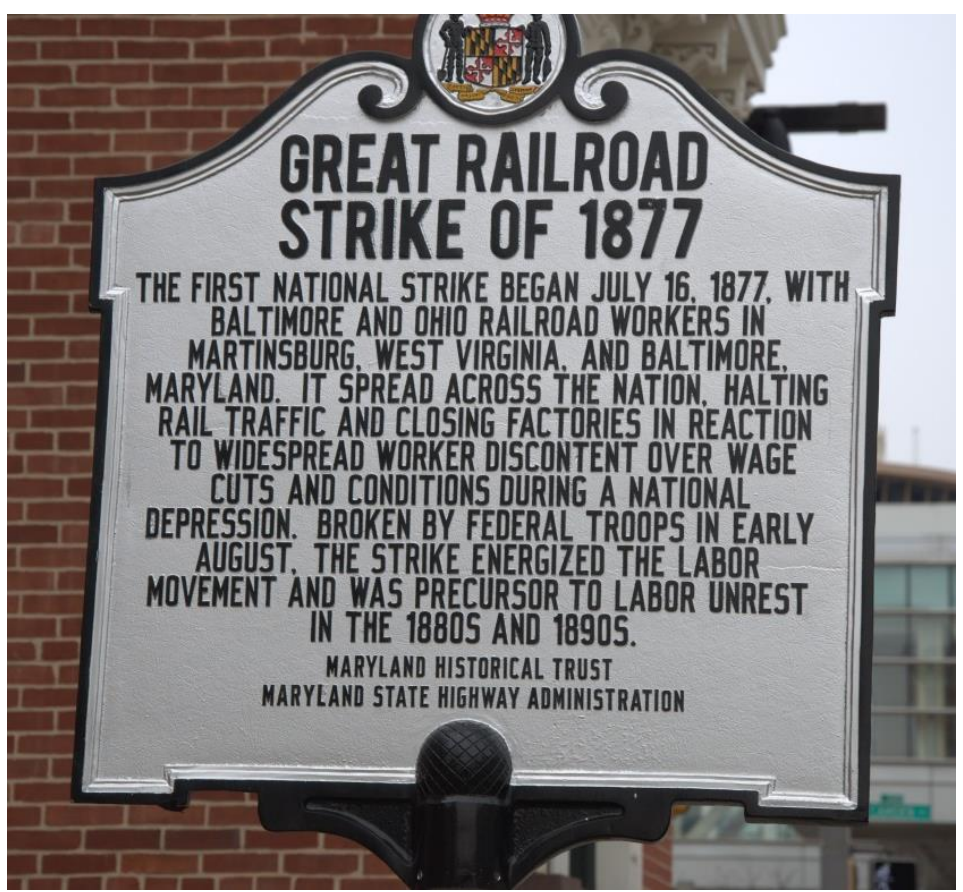

Fig. 3.4 Maryland Historical Trust and Maryland State Highway Administration Marker to commemorate the railroad strike of 1877, put up next to Camden Station in 2013. Source: Virginia Harness, February 8, 2014, Baltimore, MD. 